\title{
Emerging energy technologies
}

\section{Andersen, Per Dannemand; Michelsen, Poul}

\section{Published in:}

Risø energy report 1 . New and emerging technologies - options for the future

Publication date:

2002

Document Version

Publisher's PDF, also known as Version of record

Link back to DTU Orbit

Citation (APA):

Andersen, P. D., \& Michelsen, P. (2002). Emerging energy technologies. In H. Larsen, \& L. Sønderberg Petersen (Eds.), Risø energy report 1. New and emerging technologies - options for the future (pp. 19-22). Denmark. Forskningscenter Risoe. Risoe-R No. 1351(EN)

\section{General rights}

Copyright and moral rights for the publications made accessible in the public portal are retained by the authors and/or other copyright owners and it is a condition of accessing publications that users recognise and abide by the legal requirements associated with these rights.

- Users may download and print one copy of any publication from the public portal for the purpose of private study or research.

- You may not further distribute the material or use it for any profit-making activity or commercial gain

- You may freely distribute the URL identifying the publication in the public portal

If you believe that this document breaches copyright please contact us providing details, and we will remove access to the work immediately and investigate your claim 


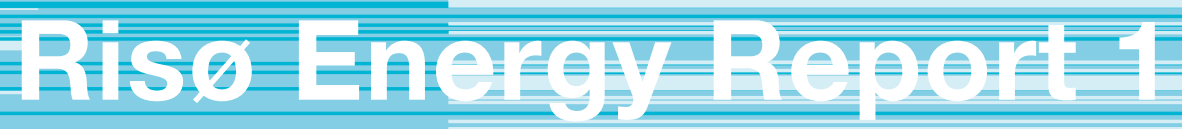

\section{New and emerging technologies \\ - options for the future}

Edited by Hans Larsen and Leif Sønderberg Petersen 



\section{Risø Energy Report 1}

\section{New and emerging technologies - options for the future}

Edited by Hans Larsen and Leif Sønderberg Petersen

Reviewed by

Robert Schock Lawrence Livermore National Laboratory, USA

and

Mariano Bauer Instituto Mexicano del Petroleo, Mexico D.F.

Consultant

Charles Butcher Science Journalist 
7.6 Combustion and gasification of fossil fuels and biomass 


\section{Preface}

All over the world, increasing energy consumption, liberalisation of energy markets and the need to take action on climate change are producing new challenges for the energy sector. At the same time there is increasing pressure for research, new technology and industrial products to be socially acceptable and to generate prosperity. The result is a complex and dynamic set of conditions affecting decisions on investment in research and new energy technology.

To meet these challenges in the decades ahead, industrialists and policymakers need appropriate analyses of energy systems, plus knowledge of trends for existing technologies and prospects for emerging technologies.

This is the background for this first Risø Energy Report, which sets out the global, European and Danish energy scene together with trends in development and emerging technologies. The report is the first in a new series from Risø National Laboratory.

The global energy developments are presented based on the latest available information from authoritative sources like IEA, WEC, World Energy Assessment etc. Some of the major challenges are presented in terms of the changing energy markets in all regions, the focus on environmental concerns in the industrialised countries, and energy for development and access to energy for the poor in developing countries.

The report presents the status of R\&D in progress for supply technologies. The various technologies are assessed with respect to status, trends and perspectives for the technology, and international R\&D plans. For the technologies where Risø is undertaking R\&D this is highlighted in a separate section.

Recent studies of emerging energy technologies from international organisations and leading research organisations are reviewed. There are reviews of national research activities on new energy technologies in a number of countries as well as in Risø National Laboratory. Conclusions for Danish energy supply, Danish industry, and Danish energy research are drawn as well as the implications for the global energy scene.

The report is thus based on internationally recognised scientific material, and it is fully referenced and refereed by an international independent expert panel. Our target group is colleagues, collaborating partners, customers, funding organisations, Danish ministries and international organisations including the EU, IEA and UN.

Hans Larsen and

Leif Sønderberg Petersen 


\section{Summary and main conclusions}

The world is facing major challenges in providing energy services for the future needs of the developed world and in particular the growing needs of the developing countries. The global energy consumption is expected to continue to grow primarily in developing countries. Their share of global energy consumption will grow from approximately 35\% in 1990 to $60 \%$ in 2050 . At European level, total energy demand is expected to increase $35 \%$ by 2030 compared to today. Energy supply security has for geopolitical reasons become an increasing concern especially in the US and the EU.

The world's future energy supply is likely to be based on open markets among countries with trade of both natural gas and electricity over longer distances than we know today. We also recognise the fact that there will be large differences between world regions with regard to energy supply, environmental preferences and economic development. For instance, developing countries are likely to give higher priority to development and access to energy for the poor than to short-term environmental protection.

As can be seen from the report, a large variety of new energy supply options are at various stages of development. Obviously, it is impossible to predict which of the options will win or be dominant in the marketplace this will be determined by future specific technological and economic developments, and by political preferences. However, as we see it, future energy supply systems are likely to become more "distributed" than they are today, and they will be based on more diverse combinations of local and central technologies.

International studies (IPCC and WEC) have analysed several alternative energy scenarios, which show that alternative policies and priorities can lead to a wide range of different energy futures. Some scenarios expect supply to be dominated by fossil fuels, with high shares of natural gas and nuclear, and slow growth in renewable energy. Other scenarios expect renewable energy such as biomass, solar and wind to make major contributions by 2050, while oil and coal decline in importance. The real future may be somewhere in between, but what is certain is that it will depend on today's political decisions on the development of new technologies and policies.

With regard to the individual technologies, we find it inevitable that fossil fuels - due to the availability of relatively cheap and abundant resources - are going to play a dominant role for several decades ahead in OECD countries, and in particular in the developing countries and countries in transition. Hence it is important to further develop clean fossil supply technologies. Advanced fuel cells are expected to be a strong option in 10 to 15 years' time for converting natural gas to electricity and heat for use locally, at central units and in the transport sector. Later on, hydrogen may become the preferred fuel.

Several renewable technologies are being developed and deployed in many countries, such as wind energy in Denmark. However, at a global level renewable energy technologies contribute little to today's energy supply, and it will take a couple of decades before major contributions are likely. At that time, we expect wind, biomass and solar to be strong candidates that could, even in a competitive market, change the energy supply towards a more environmentally benign system.

In some of the scenarios presented in the report, the next generation of nuclear power plants plays an important role in the years ahead, and later on even fusion power. Whether or not this will be the case, will - as we see it be predominantly a matter of political preferences and public acceptance in the years ahead.

\section{Key messages:}

- Security of supply may be improved by the development of more diverse and efficient energy systems and the introduction of renewable energy technologies.

- With global climate concerns and the implementation of the Kyoto Protocol, global environmental issues will have increased prominence in energy sector priorities.

- The implementation of the Kyoto Protocol is posing a significant challenge to the member states of the European Union.

- Denmark's Kyoto target is a reduction of 21\% in greenhouse gas (GHG) emissions compared to $1990.12 \%$ has now been achieved; the rest will be more difficult.

- Today $16 \%$ of electricity in Denmark is produced by wind turbines. This might be increased to 50\% in 2030 at reasonable cost.

- Green certificate markets might facilitate the introduction of renewable energy, as they are expected to reduce the costs of implementing renewable energy technologies.

- The World Energy Council has recently shown that global energy R\&D expenditure at present is far below what is needed to meet the huge challenges ahead: reducing GHG emissions and providing energy for the growing populations and development needs in developing countries.

Based on the assessment of energy technologies in national, European and global perspective presented in Chapter 7, indicators for selected energy technologies are presented on page five. The technologies were chosen 


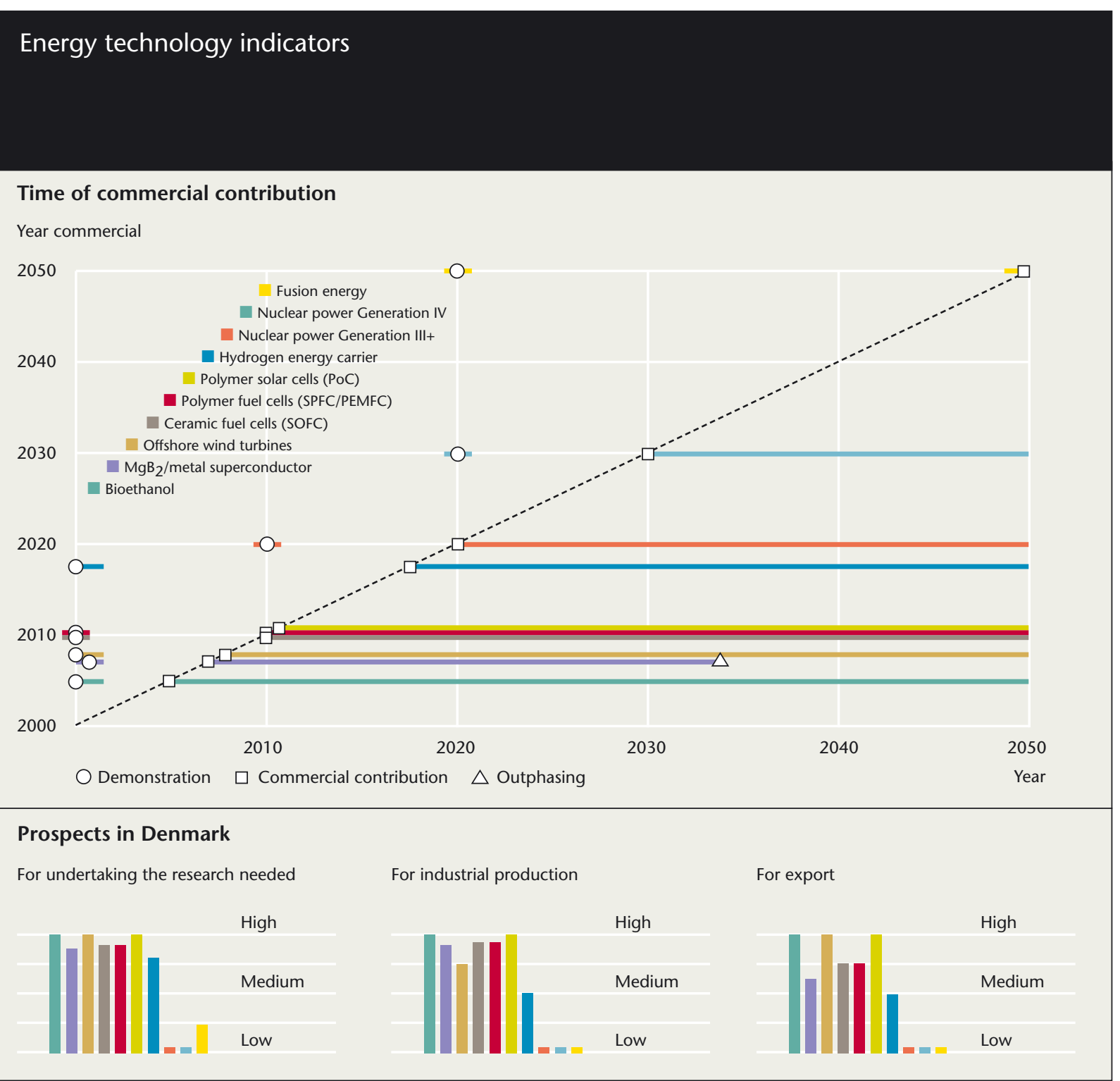

based on their prospects in Denmark in the medium term with regard to possibilities for research, industrial production and export. A number of technologies such as fusion are also included because of their long-term global prospects. It is noticeable that several new technologies such as solid oxide fuel cells, offshore wind turbines and biomass gasification are expected to be able to make contributions on a commercial scale in about ten years' time.

- New technology will play a decisive role in fulfilling the needs of coming generations, and it may facilitate the decoupling of economic growth, energy demand and environmental effects.

- Moving new energy technologies down the learning curve needs both expensive research and time for development, manufacturing and experience from deployment of the technologies.
- Wind energy technologies are already doing well in several countries including Denmark, and prospects for further development are good.

- Advanced fuel cells are expected to be a strong option for converting natural gas to electricity and heat in 10 to 15 years' time for use locally, in the transport sector and at central units. Later on, hydrogen might become the preferred fuel.

- Biofuels also have great potential for Denmark; further R\&D is still needed.

- Solar energy is in the long term expected to make a major contribution to global energy supply. Denmark has the possibility to contribute to the development of polymer solar cells.

Hans Larsen 


\section{Future energy perspectives}

KIRSTEN HALSNÆS AND JOHN M. CHRISTENSEN, SYSTEMS ANALYSIS DEPARTMENT, RISØ

\section{Energy sector development priorities}

The global energy scene is presently characterised by significant changes in the structures of energy markets: institutional and market reforms are taking place in almost all regions. While the general driving forces are to increase overall cost-effectiveness and improve the delivery of energy services, there are clear regional differences. The industrialised countries are concentrating on environmental concerns, while developing countries are more concerned with energy for development and access to energy for the poor.

Fossil fuel resources are still abundant on a global scale. Even taking into account short-term price fluctuations, the trend towards relative price stability is expected to continue for the next 20-30 years ${ }^{1}$.

There are significant regional differences, however, and the uneven geopolitical distribution of resources and demand means that any projections are subject to a high degree of political uncertainty. Security of energy supply has become an increasing concern, first in the USA and now in the EU.

Significant investments are required to ensure access to new energy resources and to deliver energy services, especially to consumers in developing countries. This is a challenge to the international finance community and industrialised countries.

Both global environmental issues and concerns about local and regional air pollution, especially in developing countries, are gaining prominence in the energy sector. International agreements on climate change are moving forward, and the Kyoto Protocol is expected to enter into force once it has been ratified in 2003.

All these trends relate to technological developments in the short or long term. With conventional fossil-fuelbased energy systems still dominating energy investment, the introduction of new and emerging energy technologies need to be assessed over a longer timescale. The IEA states in its Global Energy Outlook that production of primary energy from renewable sources is expected to grow rapidly, but that the impact of renewables on the global energy mix will remain relatively small in the next two decades. From 2020 onwards this situation is expected to change significantly, driven especially by environmental concerns, but this will require governments and industry to act together and to invest heavily in technology and infrastructure.

To better understand developments in global energy demand and production over the next 50 years, and what this will mean for technological development, we have reviewed a number of international scenario studies. These studies consider alternative patterns of future energy development, presenting them in the form of scenarios. Scenarios can be understood as alternative expectations about the future and facilitate the comparison and discussion of key assumptions.

It must, however, be emphasized that these global scenarios are at very aggregate levels and conceal large regional and national differences.

The first level of difference is illustrated directly in the scenarios which is the clear differentiation in energy demand and supply growth between the industralised and the developing countries in general, which implies that energy policies and decision making have to deal with significantly different problems. While industrialised countries will focus on substituting present supply technologies with more efficient and cleaner ones. Developing countries will be looking at significantly expanding energy supply to support economic development aspirations and providing access to more modern and efficient energy sources for the more than 2 billion people presently relying on traditional and often limited energy resources in the form of different types of wood.

The broad group of developing countries is in addition very heterogeneous. Large Asian countries like China with a significant industry sector and a population of more than 1 billion people have little in common when making decisions on energy investments with a small African state with hardly any industry and continued economic decline. At the same time most countries also have significant internal differences between the energy situation for the small wealthy part of the population and the majority which is poor, and for a rural farmer in China the energy situation is not very different from a similar farmer in e.g. Tanzania.

Broadly speaking the larger share of supply expansion will over the next decades happen in Asia with focus on the commercial and industrial needs, the situation in Latin America will be closer to industrialised countries with focus on more efficient and cleaner supply, while Africa will need to both expand commercial supply and focus on increasing access to both rural and urban poor as an integral part of a push to eradicate poverty.

These trends also imply different technological needs. Centralised options in the short term will focus on expanding and increasing efficiency of fossil fuel based supply technologies, while the poverty oriented energy development will need to focus on decentralised and flexible technological options. Here renewables are expected to be more competitive in the short term.

The large number of scenarios reflects the variety of options that can be envisaged. The Intergovernmental Panel on Climate Change (IPCC), for instance, has devel- 
oped a database of more than 400 global energy scenarios that meet sustainable development objectives.

We do not have the space in this report to describe such a large number of scenarios ${ }^{3}$. Instead, we present detailed summaries of a few key international studies, and from these we highlight the critical development issues that can shape future energy needs and technology requirements. The studies considered here are the recent Special Report on Emissions Scenarios (SRES) conducted by the IPCC $^{4}$, the World Energy Outlook from the IEA ${ }^{5}$, and Global Energy Perspectives from the World Energy Council $(\mathrm{WEC})^{6}$.

\section{Economic development, energy and environmental concerns}

The various scenarios we have studied assume different degrees of growth in the world's economy and energy consumption over the coming decades. Figure 1 shows the full range of primary energy consumption growth in the IPCC and WEC studies for the period 1990-2050.

The IEA scenarios only cover the period up to 2020, and are therefore not included in Figure 1. They follow the middle ground, with predictions similar to those of the IPCC B2 and the WEC B scenarios.

Figure 1: Trends in primary energy consumption according to the IPCC and WEC scenarios. There are large differences between the scenarios, especially for the time horizon 40-50 years from now. The IPCC scenarios predict that from 1990 to 2050, primary energy consumption will increase by a factor of between 2.2 (lowest estimate) and 4.3 (highest estimate). Most of the gap between these extremes occurs between 2020 and 2050. In the same period, the WEC scenarios predict increases of between 1.6 (lowest estimate) and 3.7 (highest estimate). The different WEC scenarios start to diverge from one another a little earlier than the IPCC scenarios. Source: IPCC, 2000; IIASA, 2002

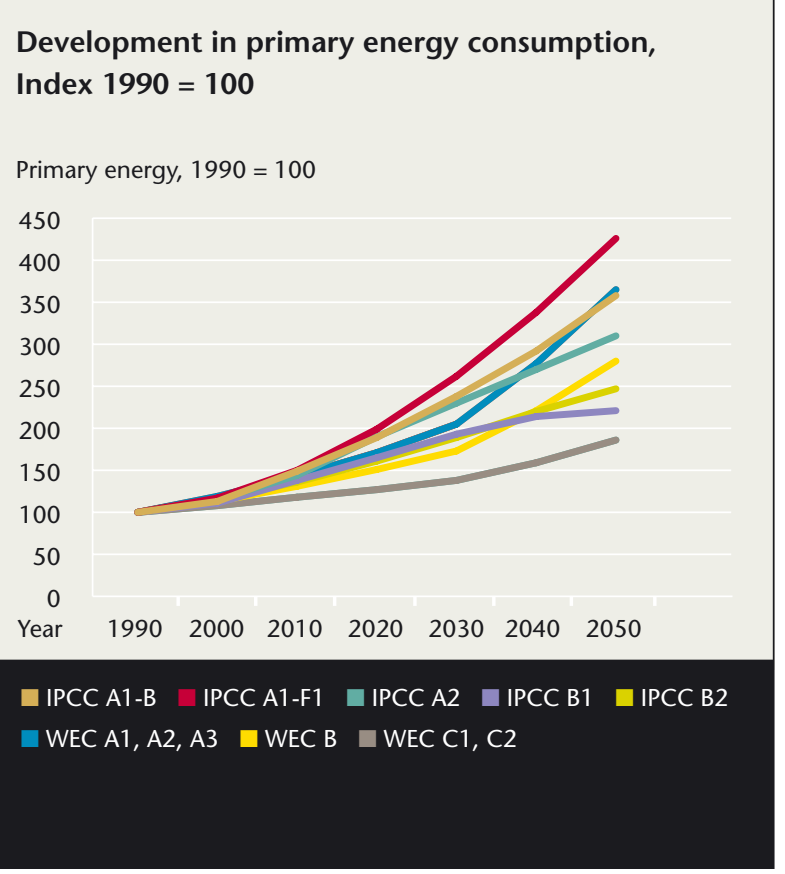

In the following sections we consider this middle ground in more detail, with a close look at the WEC B scenario, and highlight the key relationships between economic growth, energy consumption and $\mathrm{CO}_{2}$ emissions.

The WEC B scenario assumes that from 1990 to 2050 the world's gross domestic product (GDP) will grow by a factor of about 3.5 in constant price terms. Primary energy consumption will grow by a factor of about 2.2 in the same period, and $\mathrm{CO}_{2}$ emissions will increase by a factor of around 1.5 (Figure 2).

Figure 2 represents a middle course between the WEC's high-growth A1 scenario, which implies that primary energy consumption will grow by a factor of about 2.8 , and the low-growth $\mathrm{C} 1$ case, under which primary energy consumption would grow by a factor of about 1.6 .

Most of the increase in energy consumption will happen in developing countries, as a consequence of their present low consumption and high expected growth rates relative to industrialised countries. Energy consumption per capita highlights the differences between industrialised and developing countries. In 2000, North America had a per-capita energy consumption of 7.92 tonnes oil equivalents (toe), Western Europe 3.49 toe, Latin Amer-

Figure 2: Growth in GDP, primary energy consumption and $\mathrm{CO}_{2}$ emissions according to the WEC B scenario. Source: IIASA, 2002.

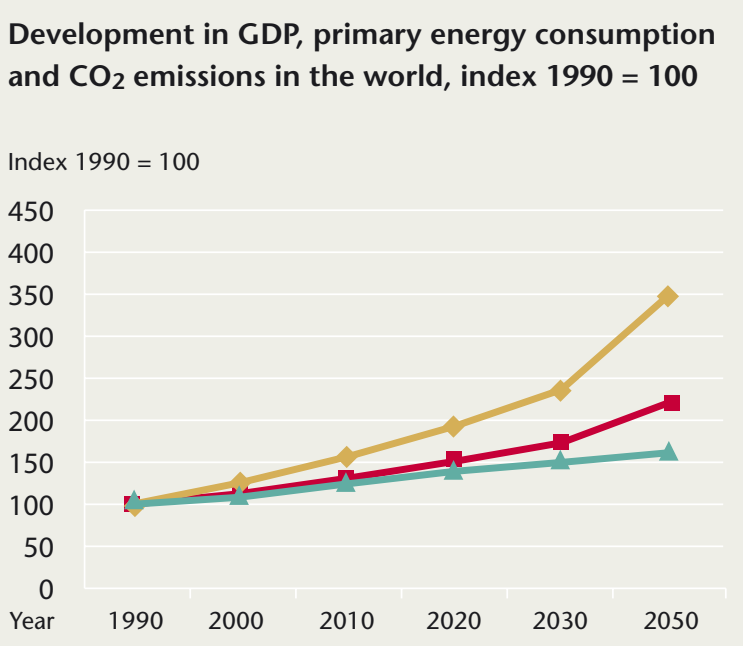

$\checkmark \mathrm{GDP} \square$ Primary energy $\triangle \mathrm{CO}_{2}$ 
ica 1.48 toe and the centrally-planned economies of Asia only 0.96 toe.

Figure 3 shows the future trends in the regional structure of global energy consumption based on the WEC B scenario.

As Figure 3 shows, the WEC B scenario predicts big structural changes in the regional composition of primary energy consumption. Industrialised countries including North America, Western and Eastern Europe, Pacific OECD and the former Soviet Union currently consume about $65 \%$ of global primary energy, but this share will decrease to around $40 \%$ by 2050 .

The main growth in primary energy consumption in absolute terms is expected to take place in Asia. By 2050 this region will consume about $35 \%$ of global primary energy, or almost 1.2 times the energy consumption of the industrialised countries in 1990.

Turning to final energy consumption, Figure 4 shows the predicted trends for electricity and the transport sector. Globally, both electricity consumption and energy for transport are predicted to grow at a rate below that for total final energy consumption from 1990 to 2050 due to the current state of energy sector development in developing countries, where energy supply for other sources are more important in their present state of development. This contrasts with the trend in industrialised countries, where electricity and transport energy will have the largest growth.

\section{Alternative energy futures}

Environmental concerns and economic efficiency

Figure 3: Regional structure of global energy consumption based on the WEC B scenario. Source: IIASA, 2002.

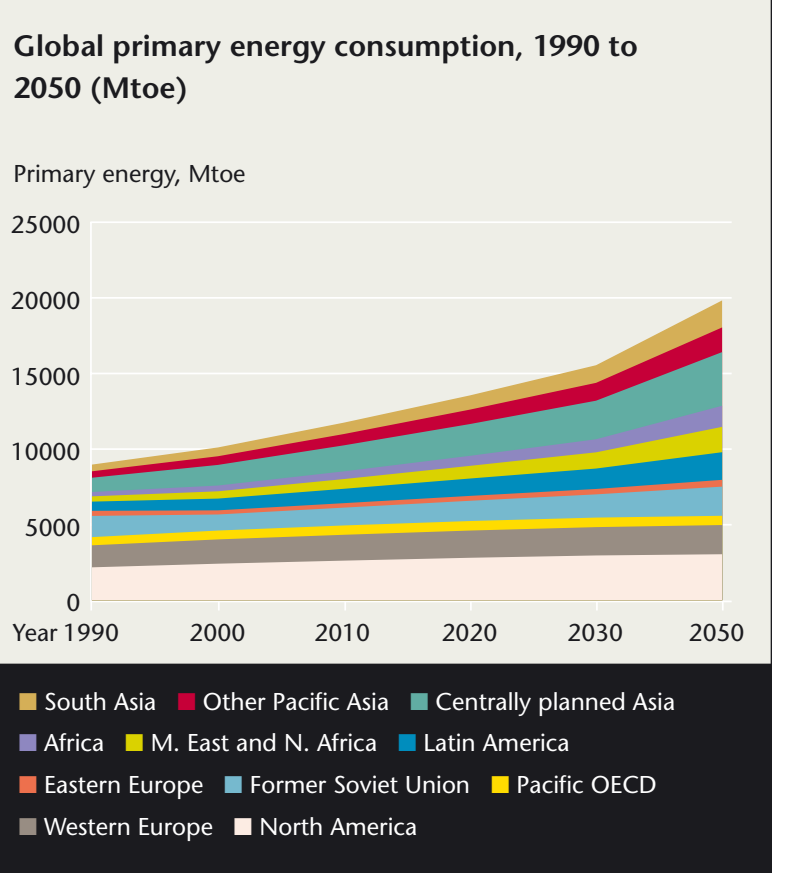

should be the main criteria for selecting fuels and energy technologies. Assumptions about future environmental policies and progress in the various energy supply technologies are therefore our starting points when predicting energy futures.

Figure 5 shows the most moderate changes in the world energy supply structure predicted from the WEC B scenario.

Figure 5 also shows that under the WEC B scenario, primary energy supply will remain dominated by fossil fuels, but their contribution to primary energy consumption will fall from almost 80\% in 1990 to about $65 \%$ by 2050 . Among the fossil fuels, natural gas will play an increasingly important role during this period. Nuclear energy is assumed to grow by a factor of nearly ten in absolute terms, an assumption that is politically unrealistic at present. Renewable energy will grow only slowly, with only biomass expected to become a significant energy source by 2050 .

The WEC C1 scenario, which gives the highest priority to environmental policies, gives a more optimistic view of the future for renewable energy sources. Under this scenario, renewables in the form of biomass and solar energy (including wind) are expected to contribute about $27 \%$ of total world primary energy consumption by 2050 (Figure 6). This ecologically driven scenario also predicts extensive use of natural gas up to 2050. In the second half of the century, natural gas would be overtaken by renewables, which would contribute more than $75 \%$ of primary energy consumption by 2100 .

A development path like the one illustrated in Figure 6

Figure 4: Final energy consumption according to the WEC B scenario, 1990-2050. Source: IIASA, 2002.
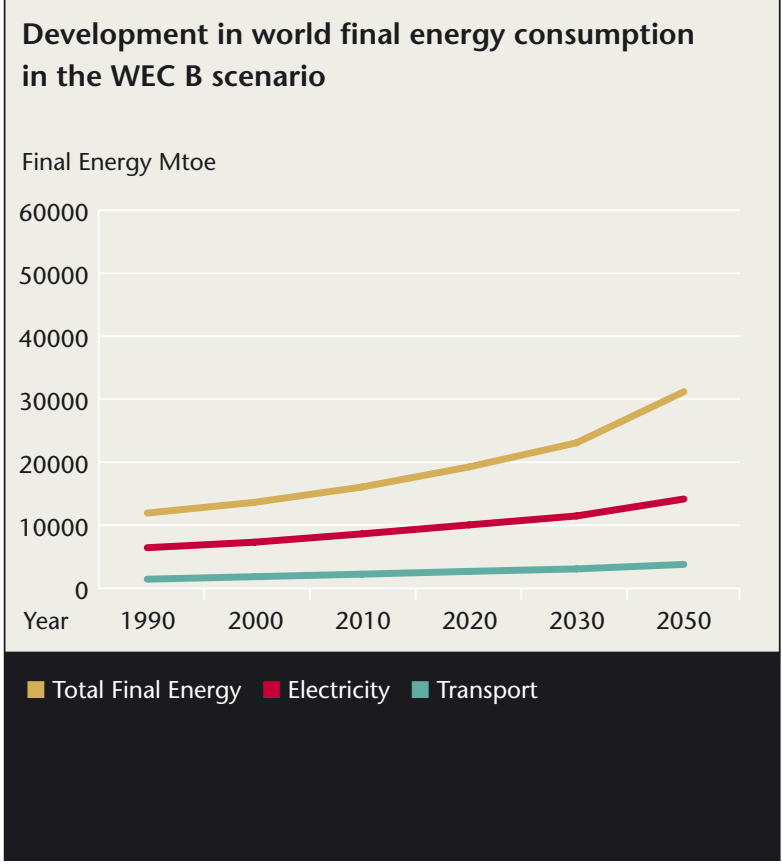
will require significant near-term investments in technology research and development. Without this, biomass and solar-based renewables will be unable to make up their assumed contributions in a cost-effective manner from 2020 onwards.

At present, the prospects for renewable energy look good, especially for wind - the renewable technology that is developing most rapidly in terms of commercial installed capacity. The IEA World Energy Outlook 2000 predicts in its reference case that electricity from wind power will increase by $12.6 \%$ a year, from $11 \mathrm{TWh}$ in 1997 to 178 TWh in 2020.

\section{Future global energy investments}

The large expected increase in global energy requirements in the next century will require correspondingly large investments in new energy technologies. Table 1 shows the accumulated energy investments by region. The WEC B scenario predicts that accumulated energy sector investments will grow significantly during the 21 st century, from a global total of about US\$ 12 trillion between 1990 and 2020, to about US\$ 22 trillion from 2020 to 2050, and up to around US\$ 82 trillion from 2050 to 2100 . The largest total investments are expected to take place in North America and in centrally planned Asia, corresponding to these regions' high share of global primary energy demand.

Figure 5: World energy supply based on the WEC B scenario, Mtoe 1990-2050. Source: IIASA, 2002

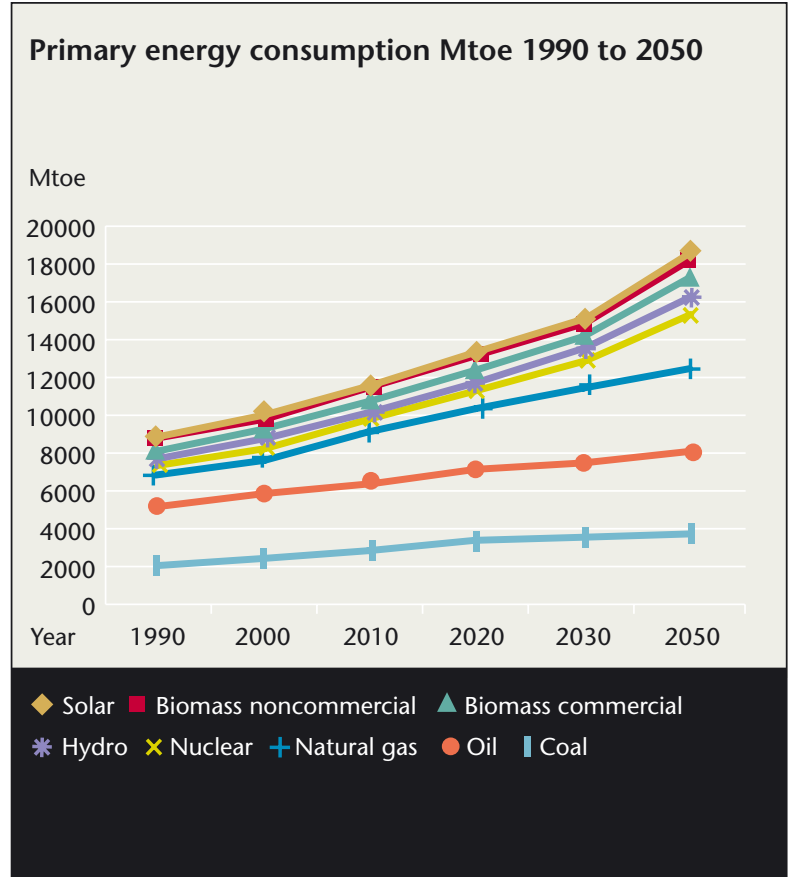

Table 1: Accumulated energy sector investments, US\$ trillion (1990), under the WEC B scenario. Source: IIASA, 2002

\begin{tabular}{|lrrr|}
\hline Region & 1990-2020 & 2020-2050 & 2050-2100 \\
\hline North America & 3.51 & 4.89 & 11.97 \\
Western Europe & 2.28 & 2.70 & 6.42 \\
Pacific OECD & 0.74 & 0.97 & 2.47 \\
Former Soviet Union & 1.51 & 2.46 & 9.19 \\
Eastern Europe & 0.39 & 0.72 & 1.98 \\
Latin America & 0.61 & 1.68 & 7.26 \\
Middle East and North Africa & 0.58 & 1.21 & 5.45 \\
Africa & 0.40 & 1.29 & 7.32 \\
Centrally planned Asia & 1.17 & 3.42 & 15.21 \\
Other Pacific Asia & 0.60 & 1.49 & 5.24 \\
South Asia & 0.54 & 1.50 & 9.70 \\
\hline World & & & \\
\hline
\end{tabular}

The fraction of this investment costs that is spent on R\&D is surprisingly low. This is especially true of renewable energy technologies, in view of their importance during the second half of the century.

\section{Further references}

Further references for this chapter are to be found in Capter 9, References, note. ${ }^{8}$
Figure 6: World primary energy consumption 1990-2100 based on the WEC C1 scenario. Source: IIASA, 2002

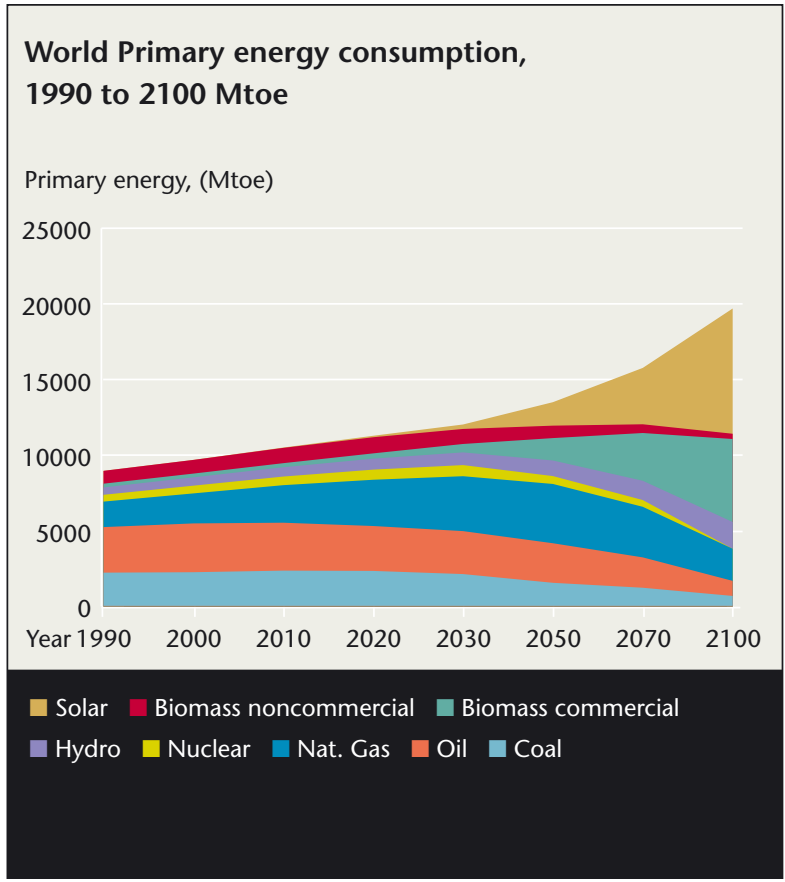




\section{Future energy perspectives: Main conclusions}

- The global energy consumption will continue to grow primarily in developing countries, their share of global energy consumption will grow from approx. 35\% in 1990 to $60 \%$ in 2050.

- Policy focus will be primarily on environmental concerns in the industrial countries and on energy for development and access to energy for the poor in developing countries.

- With global climate concerns and the implementation of the Kyoto protocol, global environment issues will have increased prominence in energy sector priorities.

- Fossil fuel resources are on a global level still abundant and prices are expected to be relatively low in the short to medium term.

- Energy supply security has for geopolitical reasons become an increasing concern especially in the US and the EU.

- Significant investments are required to ensure development of new clean energy technologies for introduction in the medium to long term.

- Market reforms are being implemented in almost all regions of the world changing both the investment and policy regimes.

- International studies (IPCC and WEC) have analysed several alternative energy scenarios Alternative policies and priorities can lead to a wide range of different energy futures.

- WEC middle scenario B, from 1990 to 2050; predicts growth in GDP 3.5 times and primary energy consumption 2.2 times and $\mathrm{CO}_{2} 1.5$ times. This scenario is expecting supply to be dominated by fossil fuel (80\% in 1990 and still 65\% in 2050), with high share of natural gas and nuclear with slow growth in renewable energy.

- A more radical scenario (C1) is expecting renewable energy such as biomass, solar and wind to contribute $27 \%$ in 2050; declining oil and coal; increased use of natural gas and a minor contribution from nuclear. A development path like this require significant near-term investments in technology research and development.

- The large increase in global energy demand in the next century will require large investments. The WEC B scenario predicts that accumulated energy sector investments will grow significantly during the 21st century, from a global total of about US\$ 12 trillion between 1990 and 2020, to about US\$ 22 trillion from 2020 to 2050.

\section{UNEP Collaborating Centre on Energy and Environment research at Risø}

The UNEP Collaborating Centre on Energy and Environment at Risø (UCCEE) focuses on integrating environmental issues into national planning and policy worldwide, as well as supporting international activities related to global and regional environmental agreements, such as the UN Framework Convention on Climate Change (UNFCCC). UCCEE was established in 1990 and is financed jointly by UNEP, the Danish International Development Assistance (Danida) and Risø National Laboratory. It is staffed by an international group of scientists, engineers and economists. UCCEE supports UNEP in pursuing its aim of incorporating environmental aspects into energy planning and policy world-wide, with special emphasis on developing countries. UCCEE works catalytically, supporting research by local institutions, coordinating projects, disseminating information, and carrying out a full in-house research programme in close collaboration with other institutions in Denmark and internationally. 


\section{Danish and European energy development}

POUL ERIK MORTHORST AND FRITS MØLLER ANDERSEN, SYSTEMS ANALYSIS DEPARTMENT, RIS $\varnothing$

Greenhouse gas (GHG) reduction is to an increasing extent at the core of the energy and environmental policies of the European Union and its member states. Under the Kyoto Protocol, the European Union agreed an overall GHG reduction of $8 \%$, relative to 1990 emission levels, over the period 2008-12.

Under the burden-sharing mechanism agreed within the $\mathrm{EU}$, reduction targets for different member states vary considerably, so some national targets are much higher than the average. Denmark, for example, is committed to reducing GHG emissions by $21 \%$ by 2012 .

The background to this ambitious target is the large amount of effort Denmark has put into energy and environmental strategies over the past 25 years. For many years Denmark's total energy consumption has been more or less static, despite economic growth, and according to the latest forecast gross energy consumption will now decrease by $2 \%$ until 2012.

The energy supply industry is expected to contribute significantly to this decrease, while consumption by manufacturing industry and households is foreseen to decrease slightly. In transport and services, however, a considerable increase in energy consumption is expected to almost outweigh the improvements made in the energy supply sector. Denmark's GHG emissions are already falling, and are now 12\% below their 1990 level, adjusted for the export and import of electricity. Although further reductions are expected in the future, Denmark will not meet its Kyoto target of $21 \%$ unless more drastic actions are taken.

\section{Cornerstones of the Danish policy agenda}

Two cornerstones of the Danish energy policy agenda that deserve specific mention are the development of an efficient energy supply, especially the use of district heating based on combined heat and power ( $\mathrm{CHP}$ ) and the development of renewable energy sources, especially wind energy, see Chapter 7.1.

In renewable energy Denmark was for many years the European front-runner, with a large wind turbine industry and extensive domestic use of wind energy. Since 2001, however, further development of Danish wind power has stalled, mainly because of uncertainty over the government's future support for renewables. In 1999 the Danish parliament agreed that a green certificate market should be in place by the beginning of 2003, but this was recently postponed until 2004-5. Denmark has been very successful in developing an efficient energy supply system, especially in the use of CHP (Figure 7). CHP's contribution to total district heating has been gradually increasing, from approximately 60\% in 1990 to more than $85 \%$ by 2001 . At the same time the share of total heating energy provided by district heating has risen from around $45 \%$ in 1990 to more than $50 \%$ by 2001.

Most of the $\mathrm{CO}_{2}$ emissions reduction of the 1990s was achieved through the development of renewables mostly wind power - and conversion to CHP. As we noted above, the further development of wind power is currently stalled, while Figure 7 shows that only a small increase in CHP use is to be expected in the future. With the two most important issues in past Danish energy policy likely to have little effect in the future, the Danish government needs to take further action if it is to achieve its Kyoto GHG reduction target.

\section{Visions for Denmark's future energy system}

To investigate the future of the Danish energy system, Risø has examined the options for large-scale use of renewable energy for power and heat production in a project carried out in collaboration with the Danish electric utilities.

The study addressed the challenges in technology and system development that would arise if regional renewable energy resources were to form the main energy inputs to the Danish power and heat supply system by

Figure 7: Source: Follow-up to Energy 21, Danish Energy Agency 1999.
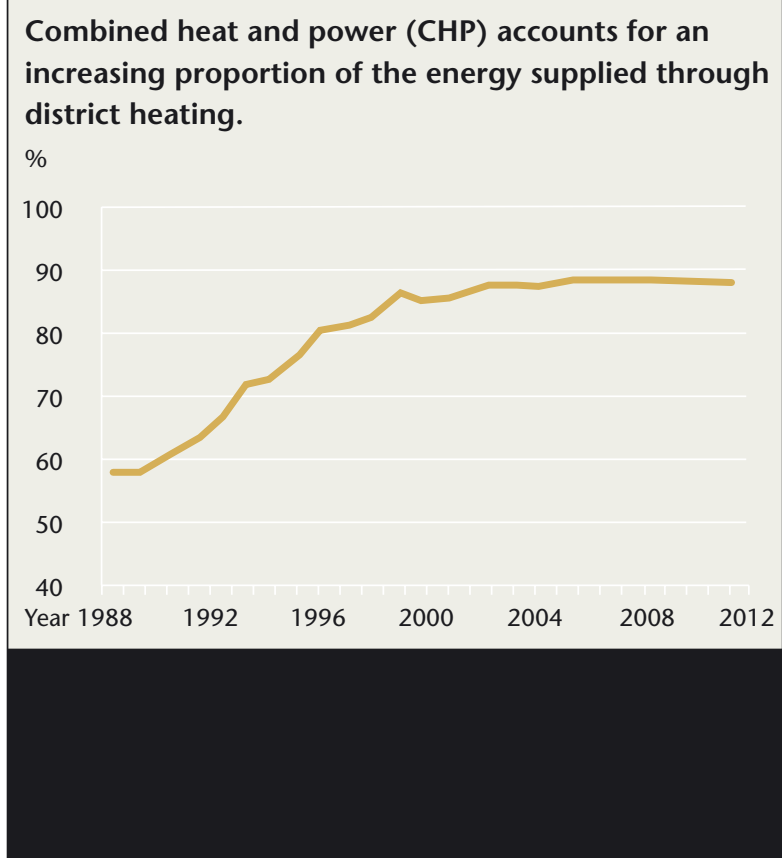
Table 2: Danish supply strategies for renewable energy resources in 2030

\begin{tabular}{|lrcr|}
\hline \% of total Danish & \multicolumn{3}{c|}{ Supply strategy } \\
electricity demand & S1 & S2 & S3 \\
\hline Wind power & $50 \%$ & $25 \%$ & $50 \%$ \\
Photovoltaics & $0 \%$ & $0 \%$ & $15 \%$ \\
Biomass & $25 \%$ & $50 \%$ & $35 \%$ \\
\hline Total & & & $100 \%$ \\
\hline
\end{tabular}

2030. Taking into account the fluctuations in energy input that result from using renewable technologies such as wind, photovoltaics and biomass, the study looked at supply strategies to provide the same quality of electric service as exists today. ${ }^{9}$

The study employed a scenario approach, with the basic aims of society at large forming the starting point for the analysis. Economic growth, fuel price developments, energy demand and energy supply strategies were then derived in such a way as to meet these fundamental aims. Three long-term electricity supply strategies for renewable energy were developed (Table 2). The S1 and S2 strategies place the primary emphasis on wind power and biomass, respectively, and both strategies aim to cover $75 \%$ of total electricity demand through renewables by 2030 . The third strategy, S3, includes photovoltaics as well as wind and biomass, and aims to meet the entire Danish electricity demand using renewables by 2030 .

Generating electricity from fluctuating energy resources - especially wind power - brings the problem of "excess electricity". To meet demand when there is little wind, generating companies must install capacity that becomes excessive when wind speeds are high.

If the proportion of electricity from wind power is low, fossil-fuel power stations can be shut down as needed to keep the system in balance. When the amount of electricity from wind power exceeds approximately $20 \%$ of the total annual electricity demand, however, it is impossible to avoid generating excess electricity. The problem of excess generation highlights the need for flexibility in the non-wind part of the generating system so that it can absorb fluctuations in wind power output. Figure 8 shows how different technologies contribute to electricity supply in the three supply strategies S1, S2 and $\mathrm{S} 3$ respectively. Wind power plays a key role in each case, providing $25-50 \%$ of total electricity demand (Table 2 ). Excess electricity and additional electricity production to operate heat pumps are included both above and below the $\mathrm{x}$-axis. Approximately half the excess electricity production in the $\mathrm{S} 1$ (wind power) and S3 (wind, biomass and photovoltaics) strategies is consumed by the heat pumps. In the S2 strategy (wind and biomass), heat pumps absorb all the excess electricity.

Substantial reductions in $\mathrm{CO}_{2}$ emissions can be achieved in the energy system as a whole and the CHP sector in particular. By 2030, $\mathrm{CO}_{2}$ emissions from the power/CHP sector would have fallen by approximately $85 \%$ and $88 \%$, respectively, under strategies S1 and S2, and by $100 \%$ in strategy S3, relative to the reference case and assuming that refuse burning is $\mathrm{CO}_{2}$-neutral. For the energy system as a whole, all three strategies show $\mathrm{CO}_{2}$ emissions in 2030 reduced by $60-70 \%$, relative to the reference and including the energy conservation measures that form part of the scenarios.

The main conclusion from the technical analysis is that it should be possible to develop effective power and heat supply systems by 2030 in which $75-100 \%$ of the electricity supply is based on Danish renewable energy resources. However, the average production cost of electricity in 2030 is expected to increase by around 30\% under strategies S1 and S2, and by around 65\% under S3, relative to the reference. In all three strategies, the composition of average production costs shifts towards higher investment costs and lower fuel costs.

There is considerable uncertainty in such long-term analyses, for example concerning available energy resources, economic growth, technology and market development*. Nevertheless, the study provides encouraging signs that a scenario in which wind energy meets $50 \%$ of society's total electricity needs is technically possible, and not altogether unreasonable in terms of cost.

\section{Action needed at a European scale}

The European Commission foresees a considerable

Figure 8

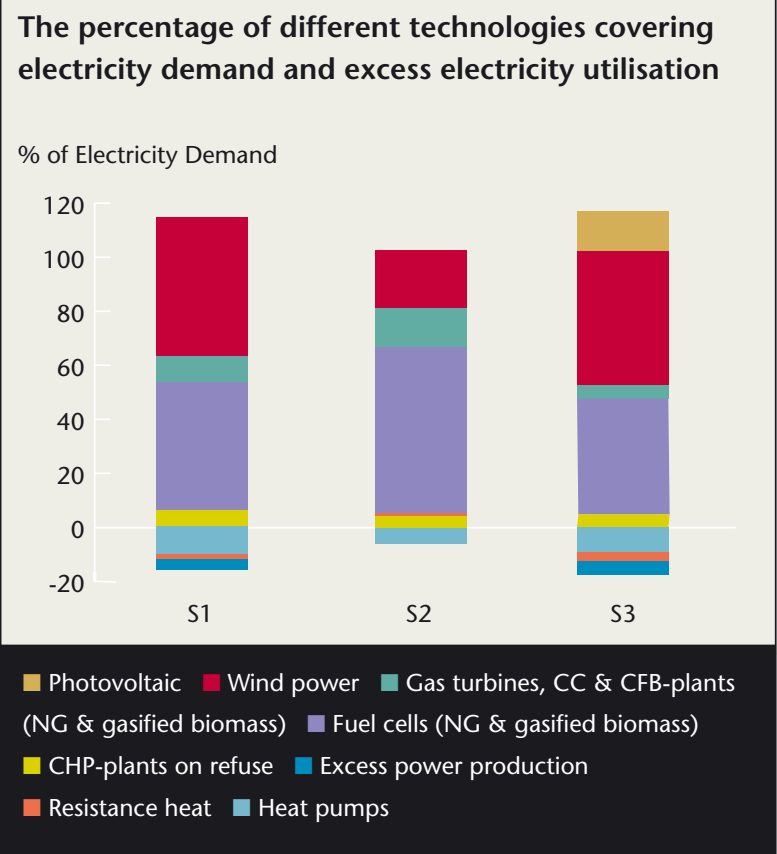

* The study does not take into account the possibilities of the interrelated power markets, but treats Denmark as a separate area. 
increase in final consumption of energy by the EU member states unless specific action is taken to change this. According to the Commission's "business as usual" forecast (the Green Paper on Security of Supply), total energy demand is expected to increase by a little more than $1 \%$ annually, producing an increase of around $35 \%$ by 2030 (Figure 9). The largest increase is to be found in the transport sector, while more moderate increases are seen in industry, services and household consumption.

This increase in energy demand may turn out to be a huge challenge to two of the most important policy areas related to environmental and energy issues: reducing greenhouse gases under the Kyoto Protocol, and achieving an appropriately secure energy supply within the EU. According to the Kyoto Protocol, the EU has agreed to reduce GHGs by $8 \%$ during the period $2008-12$, relative to 1990 . Two EU policy areas are especially important in achieving this target. The first is the EU's strategy for developing renewable energy technologies. The European Commission has set a goal of meeting $12 \%$ of the EU's gross inland energy consumption from renewables by 2010 . The most important energy sources would be biomass and wind energy, followed by hydropower and solar energy (European Commission, 1997) ${ }^{\star *}$.

In line with the White Paper on renewable development, the Commission has recently launched a directive to promote renewable energy technologies (European Commission, 2000). This includes a proposal on the share of renewables to be used in the individual member states by 2010, based on a percentage of each country's consumption of electricity.

The Directive does not say which instruments should be used to reach these targets for renewable energy, but one of the most relevant is the market for tradable green certificates (TGCs). Within the past few years green certificate markets have attracted extensive interest in Europe and elsewhere, and markets are appearing in a number of countries including Sweden, Italy, Belgium (Flanders), the UK, Australia and Denmark. In Denmark, targets for using renewable energy resources have existed for quite a long time. The Danish Parliament has agreed a national green certificate market, although recently its launch was postponed until 2004-5.

These national green certificate markets are very much in line with the fixed targets for renewable development launched by the European Commission. Although different countries have chosen different operating principles for their green certificate markets, we seem nevertheless to have a good starting point for establishing an international market - an important feature of the TGC approach.

An international green certificate market will ensure that renewable energy plants are sited and developed costeffectively: Renewable technologies will be established in

** The $12 \%$ target includes large-scale hydro, for which the potential for further exploration in the EU is very limited for environmental reasons. countries with the highest production potentials and the lowest costs. Problems in fulfilling national quotas can be handled by importing TGCs, while surplus certificates may be exported to countries with a shortage. This ensures that national targets for renewable energy technologies are reached in the most cost-efficient way.

\section{Focus on the green certificate market for renewables}

The idea of a green certificate market for renewables has attracted much attention from the scientific community. Competition in the certificate market is expected to drive down the costs of implementing renewable technologies, but prices will be set in a less transparent way than in, for instance, a feed-in tariff system. The cost advantages may be achieved, therefore, at the expense of higher risk premiums for investors.

A certificate system only supports the most competitive renewable technology. Less economic, yet still attractive, technologies will have to be supported through other mechanisms.

Establishing an efficient certificate market requires a certain volume of turnover. The small volume of the Danish national market was the main reason behind the postponement of the Danish certificate market until 2004-5. For the certificate system to work well, Denmark should become part of an international certificate trading system.

Though, a separate introduction of an international TGC market into a liberalised power market cannot be recommended, because those countries that are most ambi-

Figure 9: Source: European Commission 2001 (Green Paper on Security of Supply).

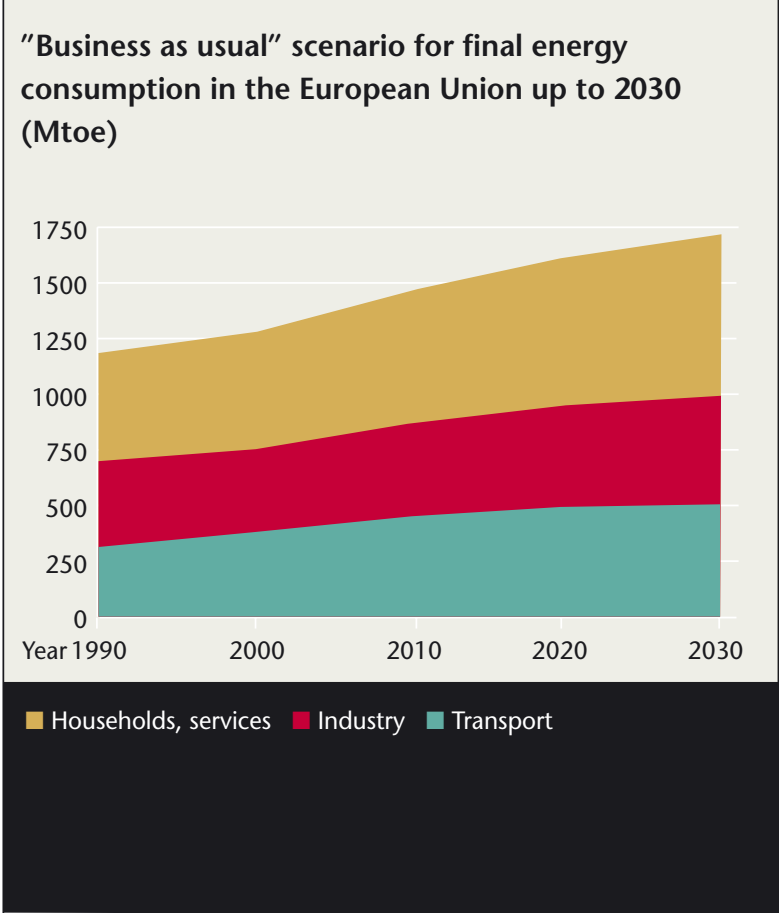


tious in implementing renewable energy technologies will gain only part of the $\mathrm{CO}_{2}$ reduction benefits themselves. A way round this problem is to back up the international TGC market with an international tradable permits market, though it will still be necessary to co-ordinate national quotas in the two markets.

Thus for an international TGC system to be relevant to GHG reduction, it is necessary to establish international emissions trading markets as well. This fits well with the second European Commission policy issue that is relevant to this discussion: the Commission's recently launched proposal for a directive on a common EU emissions trading scheme. The main idea of such a scheme is to ensure that $\mathrm{CO}_{2}$ reductions in the power generation industry and other selected industries are made in the most cost-efficient manner - that is, in those countries with the highest reduction potentials and the lowest costs. In this way, tradable permits will help to ensure that EU member states achieve their overall Kyoto GHG reduction target as cheaply as possible.

An emissions trading scheme implies higher prices in the power markets. This favours power production characterised by a low level of carbon intensity, including renewable technologies and highly-efficient plants burning natural gas.

Emission quotas for the different member states are an important policy issue in achieving the national Kyoto commitments. These quotas will also constitute part of the framework that needs to be established to interact with other Kyoto instruments, such as Joint Implementation and CDM projects.

Figure 10: Source: European Commission 2001 (Green Paper on Security of Supply).

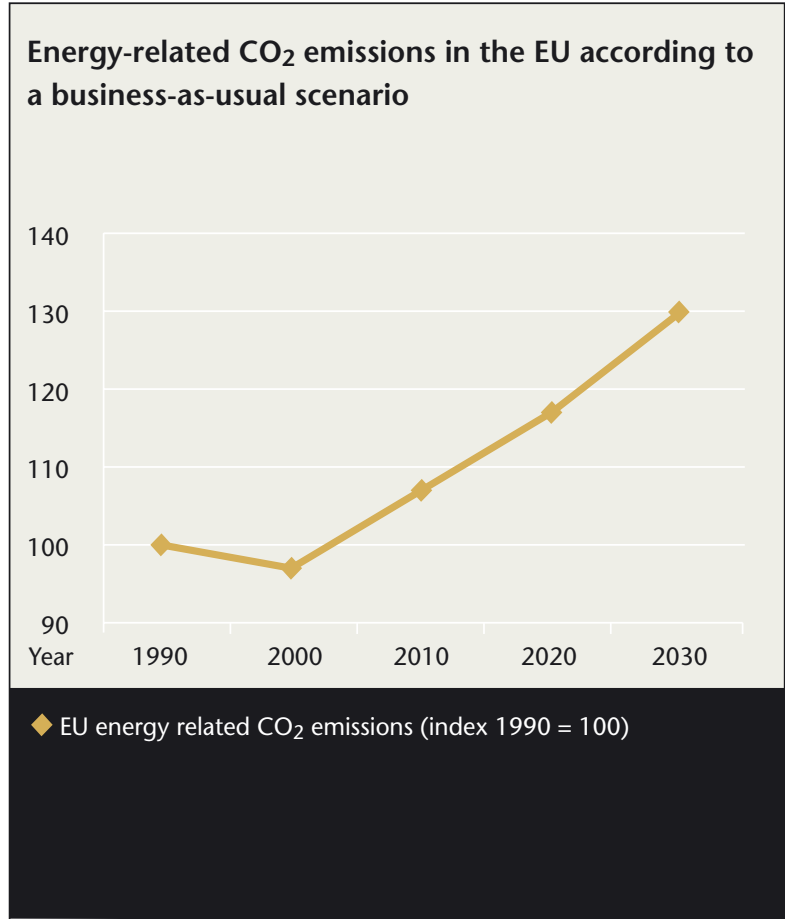

As mentioned, an emissions trading scheme will fit well with a green certificate market. In this case, however, the value of the green certificates will include only the benefit of achieving a specific target for deploying renewables, and not the benefits of $\mathrm{CO}_{2}$ reduction.

The cornerstone of future EU policy should therefore be an emissions trading scheme to help the member states achieve their Kyoto targets for $\mathrm{CO}_{2}$ reduction. With such a scheme in place, an international green certificate market may be redundant, because its objective will be limited to fulfilling the targets for deploying renewables. For countries with large domestic markets for renewables, however, national green certificate systems may still be relevant.

Figure 10 clearly shows that new instruments are needed to reduce $\mathrm{CO}_{2}$ emissions. The chart shows EU energyrelated $\mathrm{CO}_{2}$ emissions according to a business-as-usual scenario. If no specific action is taken, $\mathrm{CO}_{2}$ emissions are expected to increase by more than 30\% between 2000 and 2030. Thus there is certainly a need for increased renewable deployment and new instruments such as emissions trading, not only to meet the Kyoto targets, but even more importantly to cope with the challenge of more stringent emissions reduction targets in the postKyoto period. Security of supply is another important issue that has recently re-entered the energy policy scene. In the late 1970s and early 1980s security of supply was considered important, but later the security issue lost ground to environmental concerns. Now security is back on the agenda, as the European Commission's recent Green Paper Towards a European Strategy for the

Figure 11: Source: European Commission 2001 (Green Paper on Security of Supply).
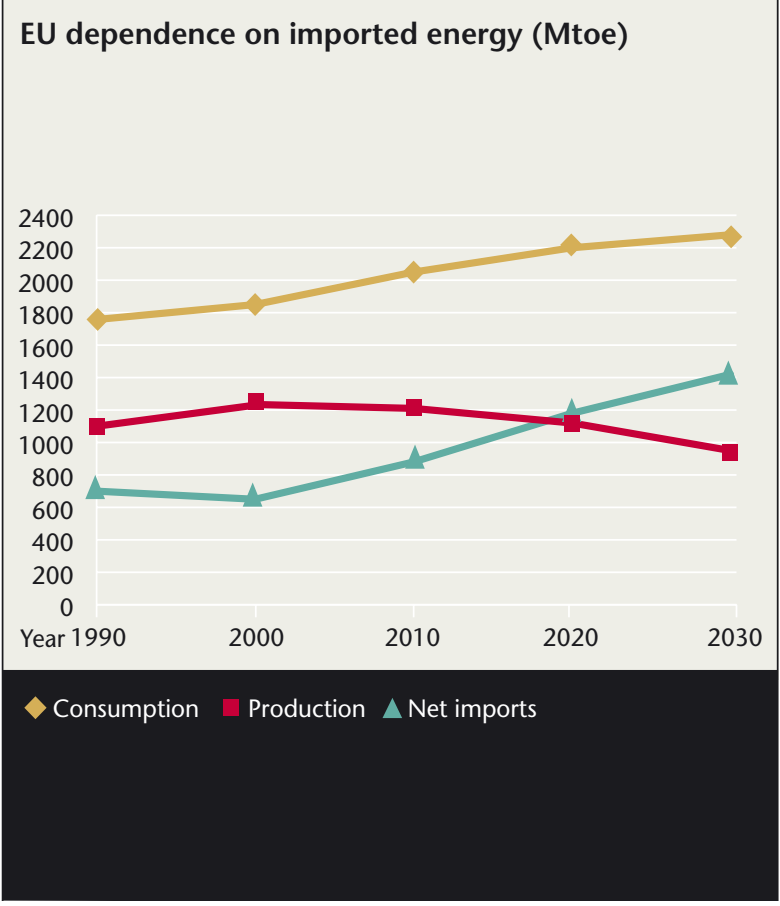
Security of Energy Supply shows. Conventional energy sources - oil, nuclear, natural gas and solid fuels - currently dominate the EU's energy supply. According to a business-as-usual scenario, these conventional sources will decline in importance in the future; only renewable sources are expected to increase. The EU's indigenous energy supply is expected to decrease considerably unless specific action is taken to change the situation.

Figure 11 shows that under the business-as-usual scenario, net imports of fuel will gradually increase until they make up around $60 \%$ of EU final energy consumption by 2030 , compared to just $35 \%$ in 2000.

To lower this dependence on energy from outside the EU, the Green Paper on Security of Supply outlines some of the elements of a long-term energy strategy. Opportun- ities to increase EU domestic energy production are limited, so focus is on reducing demand. The Green Paper suggests that this will be done mainly by changing consumer behaviour, especially through the use of taxation. With regard to energy supply, the Green Paper highlights the use of decentralised technologies and renewable energy sources. Although these will help to diversify the EU's energy sources, the Green Paper does not expect them to be significant in improving security of supply. Nonetheless, a number of new technologies now approaching commercial competitiveness are set to do their bit in reducing Europe's dependence on imported energy, as well as reducing GHG emissions, see Chapter 7.

\section{Danish and European energy development: Main conclusions}

- The Kyoto protocol has now been ratified by the European Union posing a big challenge to the member states.

- Danish gross energy consumption expected to be reduced by $2 \%$ by 2012 compared to the stable level for several years.

- Danish Kyoto targets are reduction of 21\% compared to $1990 ; 12 \%$ have now been achieved the rest will be difficult.

- Danish energy policy: efficient energy supply incl. CHP and renewable energy.

- Today $16 \%$ of electricity is produced by wind turbines, this might be increased to $50 \%$ in 2030 at reasonable costs, according to recent technical studies at Risø.

- European total energy demand is expected to increase by 35\% in 2030.

- EU Kyoto targets are 8\% GHG reductions in 2008 - 12 compared to 1990; a big challenge.

- Green certificate markets might facilitate the introduction of renewable energy as it is expected to drive down the costs of implementing renewable energy technologies.

- Certificate markets should be part of international emission trading scheme to ensure that $\mathrm{CO}_{2}$ reductions are acheaved in the most cost-efficient manner.

- Security of supply is improved through development of a more efficient energy system and the introduction of renewable energy technologies.

\section{Energy Systems Analysis research at Risø}

The aim of the research programme is to develop methods and models for analysing energy, environmental and economic issues, including integrated analysis and the adaptation of new technologies to complex energy systems. The Energy Systems Analysis Programme employs a multi-diciplinary team of about 10 scientists analysing economic and technical topics related to energy and environment issues.
The programme is part of the Centre on Environment, Economy and Society established in co-operation with the Department for Policy Analysis at NERI. The research areas covered by the centre are environmental economics, integrated environmental information systems, estimates and forecasts of emissions and sector analyses within land use, transport and energy. 


\section{Integrated energy systems}

LARS HENRIK NIELSEN, SYSTEMS ANALYSIS DEPARTMENT, RIS $\varnothing$, HENRIK W. BINDNER, PER LUNDSAGER, WIND ENERGY DEPARTMENT, RIS $\varnothing$ AND ALLAN SCHRøDER PEDERSEN, MATERIALS RESEARCH DEPARTMENT, RIS $\varnothing$

Integrated energy systems may be defined here as systems that integrate distributed generation and large-scale utilisation of fluctuating renewable energy resources, such as wind power and photovoltaics. Integrated energy systems may provide combined production of electricity, heat and e.g. fuel for transport. The interplay between conventional, new, and renewable power generation technologies and support technologies in such complex systems becomes increasingly important. Just as important are the potential system flexibility gains achievable via dynamic interaction between production and the consumption, e.g. governed via liberalised energy markets. Security of supply, system balance, and power quality are central issues for integrated energy systems.

\section{Challenges for future energy systems}

Development of flexible and cost-effective integrated energy systems is essential for meeting the challenges for future energy systems. As pointed out in Chapter 2, future energy systems must operate within severe constraints on security of energy supplies and the long-term energy resource availability, the emission of pollutants and greenhouse gases, and the systems now being planned must prepare for post Kyoto aims. Efficiency improvements throughout the energy conversion cycles applied and utilisation of the renewable energy sources are important for meeting these challenges. Barriers to such development include technical, administrative, political and legal issues.

Towards these challenges important technical and economic advancements have been made in a number of areas, and promising research and development efforts are ongoing. Among such significant advancements are:

- the development of renewable energy technologies, such as wind power and photovoltaics;

- fuel cell and electrochemical technology developments capable of offering high energy conversion efficiency and flexibility to energy systems;

- information technology (IT) and

- power electronics capable of mobilising flexibility and technical regulation for future energy systems.

The combined advancements in such areas are important. System flexibility potentials offered e.g. via fuel cell technology, IT and power electronics combined may counteract the inherent constraints of the fluctuating renewable energy resources to form well functioning and economically feasible future (integrated) energy systems.
Aspects of this challenge for integrated energy systems are outlined below.

\section{Fluctuations and flexibility}

The very large renewable energy resources becoming available may meet the main challenges, but on the other hand these pose new system integration challenges. Wind power and photovoltaics are distributed and fluctuating power sources (incl. annual and diurnal variations) that require considerable flexibility of the overall system they are part of. As long as the fluctuating power inputs are modest conventional power systems can provide such flexibility without compromising power stability and quality. Hydropower capacity based on reservoirs may in particular offer considerable regulation flexibility contributions. However, when transition towards large-scale utilisation of the fluctuating power resources approaches, power system balance, regulation capability and system stability become increasingly important issues, and must be addressed explicitly.

\section{Towards distributed production}

Fuel cell technology offers very high electric conversion efficiency (e.g. based on natural gas, synthesis gas or hydrogen), it offers excellent part load efficiency at stack level and attractive regulation and load following capability. Furthermore, fuel cells offer silent operation due to no moving parts, reduced emissions (in particular no $\mathrm{NO}_{\mathrm{x}}$ ), and their modular design is very suitable for mass production. These advantages make fuel cell technology very attractive. The modular cell stack design means that fuel cells may be used in small scale as well as large scale systems, and it is anticipated that, when economically mature, this technology will dominate future energy system developments.

Yet another very important feature of most fuel cells is their potential to work in reverse, as electrolysers. In reversed mode, electricity may be used to split water, thus producing hydrogen and oxygen. Reversible fuel cells, therefore, may function in electricity storage systems, which adapt a constant or fluctuating power supply to an independently varying consumption profile. Thus, reversible fuel cells may be complementary to other electricity storage technologies, e.g. the emerging large-scale electrochemical redox-based storage technologies.

Especially in Northern Europe substantial energy efficiency gains are achieved via combined heat and power production (CHP) and district heating. CHP based power 
generation is constrained by heat demands and its seasonal/diurnal variations, and this in combination with large-scale wind power utilisation adds to the overall system constraints especially in the winter. Photovoltaic power, on the other hand, helps to balance the demand because of a favourable production profile relative to the daily power consumption, and the reduced heat demands during the summer period.

Micro CHP such as small-scale fuel cell systems based on natural gas may become commercially available in near future. Benefits of CHP thus extend into sectors presently covered by e.g. domestic boilers, and in addition transmission losses may be reduced. Heat constrained power production concurrently increase, and excess power generation may appear still more frequent.

\section{System balance and power exchange}

Such potential excess electricity generation can be counteracted on the heat side of the system e.g. by adding heat storage systems or electrically-driven heat pumps. However, potential excess generation may efficiently be handled via power exchange (e.g. spot markets). Dynamic market pricing leads to increased demand in periods of large production at lower prices (and vice versa) in the overall (international) market. A number of actors in the market, both on the consumption and production side of the system, have flexibility to adjust consumption/ production according to dynamic prices.

Fluctuations in power production e.g. caused by fluctuations in generation from renewables and fluctuations in consumption, must be balanced to maintain grid stability. Capability for such short notice power regulation, including spinning reserve, may likewise be allocated via power exchanges (regulation or balance markets) where price settling based on bids on amounts and direction of (stand by) short notice power regulation takes place. Larger actors on the production side contribute such regulation today, but other actors may appear on such markets, including specific electricity storage actors.

Information technology and power electronics may allow for extending and opening such markets to include more actors, and this may mobilise flexibility and regulation capabilities even at the individual customer level. Two-way communication systems providing dynamic exchange of information between customer appliances and e.g. system and market operators can facilitate such development. Two-way systems furthermore may postpone and save investments in transmission and production capacity in power systems, and it can facilitate metering and accounting processes.

\section{Non-fossil future and synergistic options}

Future energy systems may develop towards systems, which not only benefit from integrating heat and power production, but move beyond into systems that benefit from synergistic gains to be achieved from combined production of heat, power and fuels for transport. Such integrated systems may have the potential eventually to leave fossil fuels behind altogether.

Links between the transport sector and the power network, which today are few, may become more numerous in the future. Electric vehicles for road transport can provide such links. Driven by severe pollution problems in urban areas, legislation and improved emission standards, most large car manufacturers aim to introduce electric vehicles on the market in near future. Hydrogen based fuel cell vehicles are silent and emit water only during operation. High cost and short range of such vehicles today and the lack of fuel supply infrastructure limit market penetration. If however, hydrogen-based fuel cell vehicles, battery-electric vehicles or other electric drive systems become part of the future transport traction system the energy supply for such fleets may introduce important new actors on electricity markets. Primarily such potential development in the transport sector may introduce new actors on the consumption side of power systems. Electrolytic production of hydrogen or direct battery recharge may take advantage of the existing power distribution infrastructure, and the potentially very high flexibility as to when recharge or hydrogen generation are activated may contribute substantial flexibility to the overall integrated system. Such increased flexibility on the consumption side of power systems consequently increases the ability of the systems to integrate further fluctuating power production, e.g. based on renewable energy sources.

\section{Further references}

Further references for this chapter can be found in Chapter 9, References, notes ${ }^{11} 121314$ 


\section{Integrated energy systems: Main conclusions}

- New integrated energy systems may provide combined production of electricity, heat and fuel for transport. Links between the transport sector and the power network may become numerous in the future.

- The trend towards distributed and fluctuating power sources requires considerable flexibility of the overall energy system.

- Fluctuation in power production must be balanced to maintain grid stability; this might be obtained through international trade with electricity; introduction of dynamic pricing and the introduction of electricity storage e.g. reversible fuel cells.

- Electrical or hydrogen vehicles may provide further flexibility to power systems.

- Information technology and power electronics will play a major role with regard to system balance and power exchange.

\section{Risø research in integrated energy systems}

Concerted research on integrated energy systems is carried out at Risø by the Systems Analysis, Wind Energy and Materials Research departments. The aim is to demonstrate future system integration options at the concrete system scheme level. Technical and economic analyses, including detailed technical simulation of technologies interaction in systems, are combined with experimental verification and measurements on system and subsystem configurations. Risø develops methods and models for analysis of energy, environmental and economic issues, including integrated analysis and the adaptation of new technologies to complex energy systems.

Development of wind turbines with improved controllabil- ity has been a major task. This has e.g. been further utilised in studies of the behaviour of complete large wind farms and development of control strategies for such wind farms to reduce the negative impact on both the grid voltage fluctuations and flicker.

In small isolated power systems with large amounts of renewable energy the overall system control plays a very important role in optimisation of the integration of the renewable energy. There has therefore been an extensive effort in the understanding of the interaction between renewable generation, conventional generation and the energy consumption. 


\section{Emerging energy technologies}

PER DANNEMAND ANDERSEN, SYSTEMS ANALYSIS DEPARTMENT, RIS $\varnothing$ AND POUL MICHELSEN, OPTICS AND FLUID DYNAMICS DEPARTMENT, RISØ

\section{Introduction}

New energy technologies will play a decisive role in fulfilling our present needs as well as those of future generations. They may also break the tight link between economic growth on one hand and increasing energy demand and damaging environmental effects on the other.

But research is expensive, technology often needs a long time to develop, and it is rarely certain that investment in a particular line of research or a new technology will turn out to be profitable. This is one of the conclusions of a recent Green Paper by the European Commission, which analyses in detail the present and future energy situation of the European Union. It recommends strongly that research into new technologies should have high priority. Emerging technologies, says the Green Paper, are likely to have an appreciable effect on the production, transport and consumption of energy in the 21 st century.

\section{Definitions and terms}

In spite of the fact that the pace of technological innovation seems to be increasing all the time, there is no generally acknowledged definition of the term emerging technologies. In a recent book from Wharton Business School, emerging technologies are defined as "sciencebased innovations that have the potential to create a new industry or transform an existing one." ${ }^{16}$ The book further distinguishes two kinds of emerging technologies: discontinuous and evolutionary.

Discontinuous technologies derive from radical sciencebased innovations. Examples include fuel cells, superconducting cables and photovoltaics. Evolutionary technologies, on the other hand, derive from the synthesis of research streams that were previously separate. Wind turbines are one example.

Emerging energy technologies comprise not just devices but also systems, practices and even behaviours. Nevertheless, most recent reports on emerging energy technologies focus on scientific research, devices and systems. Discussions seldom include enough detail about the organisational and behavioural dimensions of new technologies.

The example of natural gas shows how the energy technologies we now take for granted have only become practical after a lot of hard work on organisation and infrastructure as well as technology. Gas extracted from wells in the North Sea and elsewhere must be processed, piped over long distances to the demand centres of Western Europe, distributed to users and finally converted into heat and power. To make this possible requires vision and planning from governments, large investments from industry, and both short-term and longterm research.

This kind of large-scale new thinking will be needed for several of the emerging energy technologies that cannot easily be implemented using existing sociotechnical systems. If hydrogen is to play a similar role to that currently performed by natural gas, for example, we will need new socio-technical systems that we cannot envision and create without involving science and industry in all aspects of the hydrogen energy system.

Technology foresight has become a promising policy tool for "wiring up" and strengthening links between the key actors in such innovation systems. ${ }^{17}$ Foresight projects have been carried out on energy research and energy technologies in countries all over the world.

Ultimately, new energy technologies must compete with existing technologies on the costs of the energy they produce. These costs include both direct and indirect costs, such as environmental costs.

Several studies have demonstrated that investments in emerging technologies will normally drive down costs to the point where the new systems become competitive. This is referred to as the experience curve or learning curve for a particular technology. Both scientific research and practical experience can contribute to the experience curve, but for most technologies by far the most important tool for cost reduction is industrial experience in developing, manufacturing and deploying the technology.

The importance of manufacturing experience has implications at policy level, as pointed out by Wene ${ }^{18}$ : "a system that has no output will not learn, meaning that a technology which is not produced and deployed cannot start the ride down the experience curve. Technologies cannot become cost-efficient by laboratory R\&D alone".

Pure research and applied R\&D in laboratories can demonstrate the potential feasibility of a technology. Early use of a technology can be supported by advanced users or by governments through demonstration programmes. But the process of technological and industrial learning requires long-term, stable policies for markets as well as for research.

OECD/IEA ${ }^{19}$ points out that the success of renewables ultimately hinges on their acceptance by consumers as "value-competitive". This may occur in a niche market, in more broadly-based market for a specific service, or in a general energy market. 
The same report discusses policies for sustainable transport, and notes that to introduce a new technology we must consider three dimensions: economic, social and environmental. These three dimensions apply equally to new energy technologies.

\section{Research in new energy technologies}

Since emerging technologies under the Wharton definition are closely related to science-based innovations, it seems natural to examine the world's expenditure on energy R\&D. Our starting point is the IEA's comprehensive analysis of government energy R\&D expenditure by country. ${ }^{20}$

The energy research carried out by any country reflects that country's priorities in energy policy. Thus the two IEA member countries most committed to nuclear power, France and Japan, also give high priority to nuclear research. Countries such as Denmark and Germany concentrate their research on renewable energy, where they believe the future lies. The UK and the USA have less tradition of "picking winners", and focus much of their government energy $\mathrm{R} \& \mathrm{D}$ on generic research instead.

There are large differences between different countries' expenditures on government energy $R \& D$ as a percentage of GDP. At the top of the table are countries such as Japan and Finland, which spend nearly $0.09 \%$ of their GDP on government energy R\&D. Denmark ranks near the middle, and at the bottom are countries such as the UK, which spends only $0.005 \%$ of its GDP on government energy R\&D.

Overall, nuclear energy - both fission and fusion accounts for the largest slice of government energy R\&D: $38 \%$ according to the OECD/IEA (1999) and more than $50 \%$ according to the WEC (2001).

According to the IEA, total expenditure on government energy R\&D has been falling since the end of the 1980s at the rate of around 15\% in ten years (Figure 12), but with relatively large variations from year to year and between individual countries. In 2002, for example, the new Danish government halted around three-quarters of the country's targeted energy research programmes.

A recent report from the $\mathrm{WEC}^{21}$ elaborates on recent trends in energy R\&D:

- overall (public and private) energy-related R\&D expenditure has declined;

- government energy-related R\&D expenditure has declined rapidly;

- industrial energy-related R\&D expenditure has increased slightly; and

- energy-related $R \& D$ expenditure as a percentage of all R\&D is significantly lower than the share of GDP accounted for by the energy sector.

This leads the WEC to conclude that energy-related R\&D expenditure is now dangerously low in relation to other technology-intensive economic sectors.
This is a problem both for society and for industry. Society needs energy R\&D to mitigate the serious environmental effects of today's energy technologies and to reduce strategic dependence on imported fossil fuels. Industry needs long-term, government-funded research to maintain its competitiveness in the years to come. It is the job of government, not industry, to envisage and forecast developments in energy technology and environmental issues 20 years into the future.

Accordingly, the OECD/IEA recommends that governments should increase long-term energy $R \& D$ and provide a good environment for private-sector $\mathrm{R} \& \mathrm{D} .^{22}$

\section{New energy technologies}

In recent years a number of "millennium papers" from international energy organisations such as the WEC and the IEA have reviewed energy technologies for the 21st century. The IEA has identified a number of promising energy technologies that could reduce $\mathrm{CO}_{2}$ emissions within the timescale of the Kyoto Protocol (up to 2020). The IEA assumes that within this timeframe, natural gas will be the main fuel for new fossil-fuel power plants in IEA member countries. Other assumptions are that no new nuclear power plants will be ordered in IEA member countries outside Japan and France, and that there will be no major changes in energy infrastructure.

Table 3 shows the energy technologies identified by the IEA as meeting these preconditions. Most of the technologies on this list are commercially available today or are on the point of being brought to market.

Figure 12: Sources: Energy Policies of IEA countries, 2002 Review. Forthcomming.

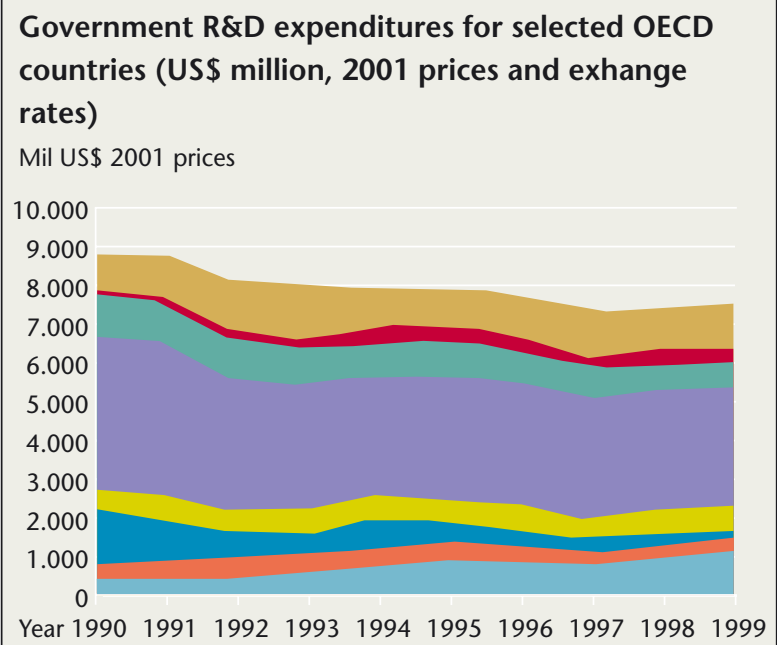

u Other Technologies/Research $\quad$ Power and Storage

a Nuclear fusion $\quad$ Nuclear Fission Renewables

n Coal $\square$ Oil \& Gas n Conservation 
Several organisations have also reviewed energy technologies and R\&D for the post-Kyoto era, after 2020 . They fall into four groups:

- energy efficiency in buildings, industry and transport;

- power generation based on fossil fuels, renewables and nuclear;

- generic or crosscutting technologies; and

- carbon sequestration.

In the following sections we will discuss generation technologies and crosscutting technologies, as the focus of this report is set on technologies for energy supply and transformation.

\section{New generation technologies}

Besides wind turbines, biomass, photovoltaics and fuel cells, new generation technologies comprise thermochemical conversion of solar energy to chemical energy carriers such as hydrogen, synthesis gas and metal hydrides, which are still in the research phase, though these technologies might become commercially important within a few decades.

Another area of long-term research is advanced solar photoconversion. This includes natural and artificial photosynthesis processes that might one day produce hydrogen, biodiesel, methane or methanol from water, biomass, waste and $\mathrm{CO}_{2}$.

Over recent years a number of research projects on "zero emissions technologies" for fossil fuels have started up all over the world. ${ }^{23}$ Zero emissions technologies allow power stations to convert fossil fuels to electricity with no net emissions of $\mathrm{CO}_{2}$, either by capturing the $\mathrm{CO}_{2}$ at the power station or by storing (sequestering) an equivalent amount of $\mathrm{CO}_{2}$ from some other source.

Other emerging energy technologies include geothermal energy, advanced hydropower and solar thermal electric power. These technologies have been demonstrated in different parts of the world over several decades, and under favourable geographical conditions they could provide competitive sources of energy in many countries.

\section{New cross-cutting technologies}

Emerging energy technologies rely on a wide range of generic or cross-cutting technologies and fields of science. The emerging generic technology with potentially the highest impact on the world's energy systems is the use of hydrogen as an energy carrier. These technologies comprises among others hydrogen, superconducting materials which are described in Chapter 7.

Much of this research will take advantage of nano-science and nanotechnology - scientists' recently-developed ability to analyse and synthesise materials at the atomic level.

Computational sciences are expected to expand the possibilities for simulating nature's forces (e.g. wind and water resources) and energy systems (local and global) and new sensor technologies will increase the potential for modelling and controlling energy systems as well as new energy technologies.

Finally, biotechnology offers a range of long-term opportunities for energy technologies. Scientists are working on genetically-modified crop plants that can operate as miniature factories to produce specific fuels and chemicals. Also on the biotechnology research agenda are new ways to transform raw biomass or organic waste into replacements for fossil fuels.

\section{Further references}

Further references for this chapter can be found in Chapter 9, References, note. ${ }^{24} 252627282930313233$

Table 3: Promising energy technologies for 2012-2020.

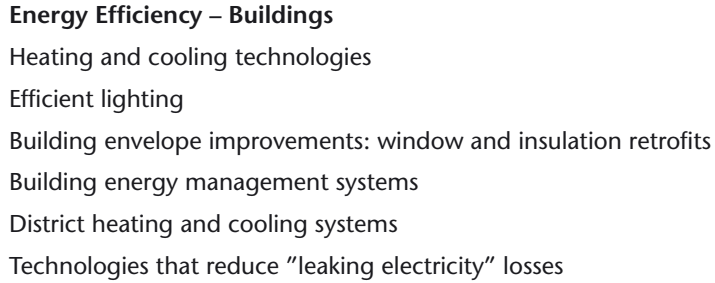

Energy Efficiency - Industry

Process integration

High-efficiency motors, drivers and motor-driven systems

High-efficiency separation processes

Advanced end-use electro-technologies

Energy Efficiency - Transport

Efficient conventional vehicles

Electric and hybrid vehicles

Bio-fuels

Clean Power Generation

Naturalgas-fired technology

More efficient coal technologies

Renewable energy technologies: Biomass and wind

Technologies for nuclear plant optimisation and life extension

Fuel cells for stationary generation

\section{Crosscutting Technologies}

Combined heat and power

Advanced gas turbines

Sensors and controls

Power electronics

Carbon Sequestration

$\mathrm{CO}_{2}$ separation

Geological storage of $\mathrm{CO}_{2}$

Source: OECD/IEA, 2000, p. 34. 


\section{Emerging energy technologies: Main conclusions}

- New technology will play a decisive role in fulfilling the needs of coming generations, and it might facilitate the decoupling of economic growth, energy demand and environmental effects.

- Moving new energy technologies down the learning curve needs both expensive research and time for development, manufacturing and experience from deployment of the technologies.

- The World Energy Council has recently shown that global energy R\&D expenditures at present are far bellow what is needed to meet the huge challenges ahead; GHG emission reductions and providing energy for the growing population and development in developing countries.

- New energy technologies for the post Kyoto era of 2010 to 2020 can move along a learning curve and cut cost of equipment such as renewables like wind, solar and biomass and zero emission fossil technologies.

- New cross cutting technologies might provide potential benefits that no single technology can match; e.g. hydrogen as an energy carrier and sensors and power electronics to improve system efficiency.

\section{Technology Foresight at Risø}

The Technology Scenarios research programme at Risø focuses on longer-term perspectives in science and technology. The aim of the programme is analyses of commercial, societal and scientific possibilities and consequences in relation to selection, development and commercial application of new technologies.

The programme employs a multi-disciplinary team of about seven scientists combining competences such as engineering, natural science, political science, strategy and innovation studies. Among the research methodologies are: Scenarios, Delphi-studies, experience curves, road-mapping, risk analysis and life-cycle analyses. The programme participates in national and international networks and projects on technology foresight and R\&D priority-setting. 


\section{Energy technologies in national, European and global perspective}

The following chapter presents the status of $R \& D$ in progress for selected supply technologies. Selection is based on evaluation of technologies characterized by requiring larger research efforts and having significant long term potential.

The presented technologies are assessed with respect to status, trends and perspectives for the technology together with international R\&D plans. For the technologies where Risø is undertaking $R \& D$, this is highlighted in a separate section.

Conclusions are drawn for each technology in the form of simple, graphical indicators for the technology. These indicators are based on a "best estimation" by the researchers at Risø on a soft scale varying from low to high, to reflect the uncertainty in such estimations.
The graph "Time to contribution" shows the phases in the development of the various technologies from the first demonstration to outphasing.

Along the $\mathrm{X}$-axis is shown the time to the first demonstration of the technology, and the point when the first units of the technology are for sale on a commercial basis as well as the span of time it is expected to be in the market. To enhance the overview the technologies are ranked along the Y-axis according to the expected time to commercial contribution.

As regards market potential the bar varies from local to broad. Local is defined as selected, special applications. Broad is defined as widespread use for large scale energy production throughout the country. 


\section{Wind energy}

PETER HAUGE MADSEN AND EGON T.D. BJERREGAARD, WIND ENERGY DEPARTMENT, RIS $\varnothing$

\section{Status of wind energy technology}

According to a recent study, ${ }^{34}$ global wind generating capacity increased by some $6800 \mathrm{MW}$ in 2001, an annual growth of just over half the corresponding figure for 2000. 2001 was the third consecutive year in which new wind power capacity exceeded new nuclear power capacity, showing the maturity of wind power technology. ${ }^{35}$ Total installed wind power worldwide by the end of 2001 was close to $25,000 \mathrm{MW} \cdot{ }^{36}{ }^{37}$ Figure 13 shows the global development of wind power capacity since 1983.

Europe leads the world in both the technology and the application of wind power. Germany, Spain and Denmark are the main players, accounting for $56 \%$ of the world's capacity increase in 2001 and a total cumulative installed capacity of $14,750 \mathrm{MW}$, or $59 \%$ of the global total. 38394041

The USA and India are also significant users of wind power; in 2001 the USA added $1700 \mathrm{MW}$ of new installed capacity to become the world's second-largest market for wind power. The tax credit known as PTC, which is an important incentive for US investment in wind power, has recently been extended for two years. ${ }^{42} \mathrm{~A}$ number of other countries including Japan and France are now starting to invest in wind power.

World market shares for the manufacture of wind tur-

Figure 13

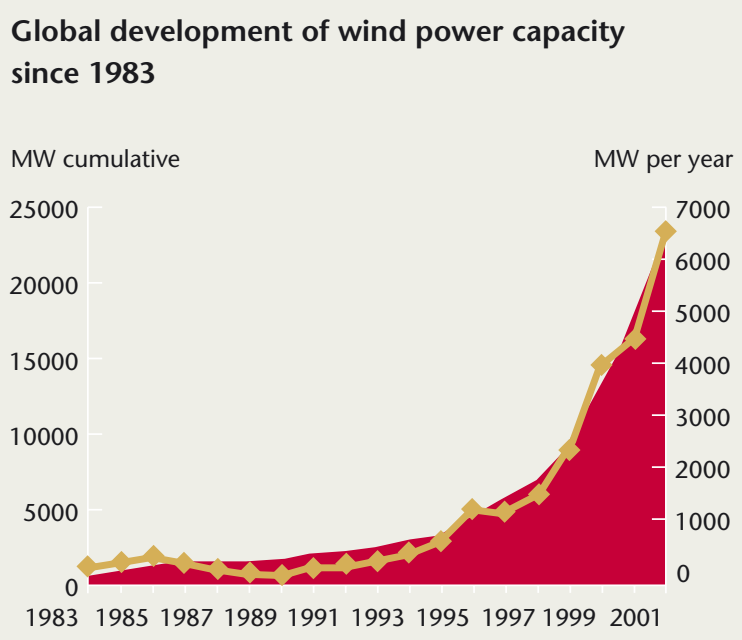

Annual Cumulative bines in 2001 were: Denmark about 45\%, Germany about $24 \%$, Spain about $12 \%$ and the USA about $13 \%$. The world's largest wind turbine manufacturer is the Danish company Vestas, which markets a pitch-regulated machine with a standard gearbox drive train. In 2001 the German company Enercon became the secondlargest supplier, pushing the Danish company NEGMicon into third place. Enercon produces a gearless machine with a direct-driven multipole generator. In 2001 the Danish wind turbine industry, including subsuppliers, employed an estimated 20,000 people.

Denmark's continuous support for wind energy since the beginning of the 1980s has produced an installed wind energy capacity of approximately $2500 \mathrm{MW}$ by the end of 2001. In a year with average wind conditions, wind energy covers almost $17 \%$ of Denmark's electricity demand.

Land-based wind turbines are still cheapest, but wind conditions at sea are considerably better. Offshore wind farms are therefore expected to become competitive in step with the development of suitable technology, ${ }^{43}$ expanding within a few years to $6-8 \%$ of the world wind power market from less than $1 \%$ today.

The wind energy industry is becoming increasingly international as wind turbines increase in size and the world market develops. "The market is still mainly driven by politics, but wind energy can compete economically with fossil fuels if we include "externalities" - the cost of pollution - associated with fossil fuel power stations (Figure 14)."

The figures quoted so far cover grid-connected wind turbines with capacities of $50 \mathrm{~kW}$ and above. Huge numbers of smaller turbines, from $500 \mathrm{~W}$ to $50 \mathrm{~kW}$, are used for local electricity production, pumping water or desalination, mainly in areas where the cost of conventional energy production is very high. Despite their numbers, though, these small turbines have a total capacity estimated to be less than $1 \%$ of that of their larger cousins.

\section{Trends and perspectives}

According to several reports, ${ }^{44} 4546474849$ the world market for wind power will continue to grow at a rate similar to that of the previous five years. The report Wind Force $10^{50}$ outlines a scenario in which wind power provides $10 \%$ of the world's electricity by 2020 , corresponding to a total installed capacity of $1200 \mathrm{GW}$.

The European Commission White Paper gives a target of $40 \mathrm{GW}$ of installed wind power in Europe by 2010. In 2000 the European Wind Energy Association (EWEA) proposed $60 \mathrm{GW}$ by 2010 , and suggest that $150 \mathrm{GW}$ by 2020 would be a realistic goal. ${ }^{51}$ 
Risø's System Analysis Department has looked at the possible future costs ${ }^{52}$ of electricity produced by wind turbines compared to conventional power as shown in figure 15. The forecast is based on a learning curve analysis of historical data - the bars in the figure indicate the kWh-cost of electricity produced by wind turbines sold and installed the particular year atypical wind regimes, characterized by roughness class 1 or 2 at the site. The analysis results in a progress ratio (or learning ratio) of 0,85 . This means that for every doubling of the installed capacity, the cost of wind-generated electricity is reduced by $15 \%$. With a growth as experienced during the last 8 years, the global installed capacity is doubled every three years, hence within 5-8 years wind-generated electricity is expected to be fully economically competitive with electricity from new conventional power technologies. The present cost of new established natural gas fired power production is shown to the right in figure 15 for a low and a high utilisation time.

Until recently the main driver for wind power has been a concern for greenhouse gases. Security of energy supply has now become an important issue, however, especially in Europe and the USA. Wind power plants can be erected at short notice and in a modular fashion that allows capacity to be added as required.

Offshore wind farms, such as the test installations at Horns Rev and Rødsand in Denmark, lead to the development of very large wind turbines. The Horns Rev farm, which has 80 Vestas wind turbines of $2 \mathrm{MW}$ each, is expected to be completed in 2002. Rødsand will have 72 Bonus 2.2 MW turbines and will be completed in 2003. Wind turbines with up to 5 MW capacity and rotor diam-

Figure 14

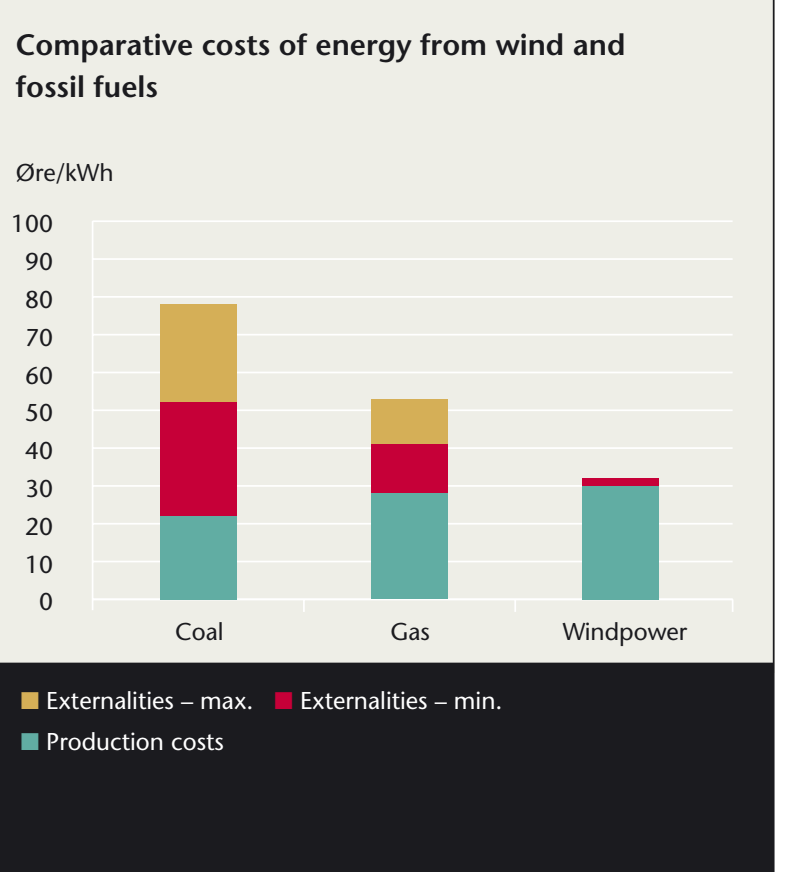

Table 4: Trends and driving factors in wind turbine development.

\begin{tabular}{|ll|}
\hline Trend & Driving factors \\
\hline Cost reduction & $\begin{array}{l}\text { Competition in liberalised energy markets; tech- } \\
\text { nology R\&D; stable market growth; improved } \\
\text { financing schemes }\end{array}$ \\
Larger turbines & $\begin{array}{l}\text { Improved design methods; R\&D in aerodynam- } \\
\text { ics; research into the nature of wind; new materi- } \\
\text { als; generators and transmission systems; control } \\
\text { Systems; noise reduction } \\
\text { farms }\end{array}$ \\
Interaction between wind and waves; founda- \\
tions; transmission and transport; monitoring; \\
operation and maintenance \\
Power system balance and stability; controllabil- \\
ity; energy storage
\end{tabular}

eters of $125 \mathrm{~m}$ are now on the drawing board in the Netherlands, Germany and Denmark.

Land-based wind turbines are also getting bigger. In 2001 the average size of installed onshore wind turbines in Germany was almost $1.3 \mathrm{MW}$, up from less than $600 \mathrm{~kW}$ five years earlier. The biggest wind turbines on the market in 2002 will be approximately 3 MW.

The move to very large wind turbines and new designs for offshore use calls for research to help optimise the generating efficiency, cost and reliability of the next generation of machines.

Table 4 shows the main challenges.

A significant trend in wind turbine technology is the increasing application of variable-speed and direct-

Figure 15

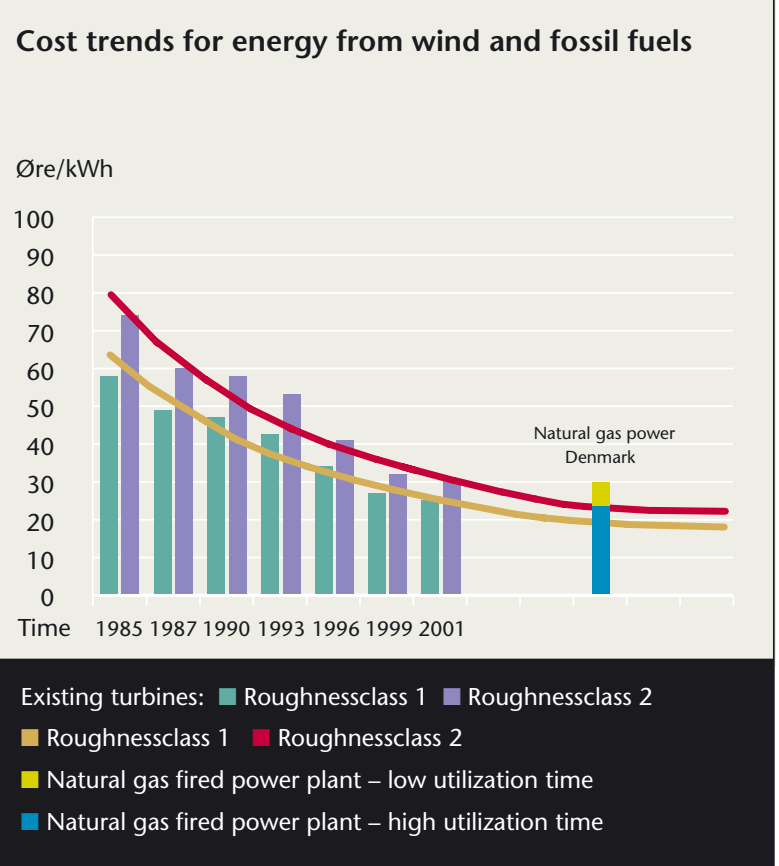


driven multi-pole generators. Danish and other European manufacturers wishing to sell wind turbines in the USA face a barrier in the form of a US patent on variablespeed technology. The gearless direct-drive concept used by the German company Enercon and the Dutch manufacturer Lagerwey has now also been adopted by the Spanish company Torres SA. Radical increases in rotor diameter, meanwhile, call for new composite materials and new designs with optimised weight/performance ratios.

Small machines in the kW class used to generate domestic electricity form a niche market with a relatively high capital cost per kW. Research projects are now under way in the USA and Europe to develop more cost-effective and reliable small wind turbines and hybrid systems for remote areas.

Expanding the market for small wind turbines requires political and economical incentives to encourage their use in developing countries or in regions with less developed infrastructures. According to the March 2001 issue of Wind Directions magazine, the world market for small wind turbines is increasing at 35\% annually and will reach around DKK 1.3 billion by 2005 . This figure would represent $90-100 \mathrm{MW}$ of generating capacity, which is less than $1 \%$ of the predicted total wind power market in 2005.

At a Danish workshop in 2001, researchers from universities and research laboratories drew up the following vision for the future of wind technology:

"The wind turbine of the future is a controllable, flexible and adaptive system characterised by a large amount of advanced technology. It is adapted to the environment in its design and operation, and has a sustainable life cycle."

"The turbine is 'intelligent', using computer controls to optimise its operation to suit local conditions. The choice of turbine size and technology is optimised for the application, with highly reliable and very large (10-20 MW) wind turbines for offshore wind farms and remote areas, and medium-sized machines with minimal environmental impact for distributed installations on land."

"The turbines use both decentralised and centralised systems to control variables such as rotational speed and power output according to wind, grid or market conditions."

"New technologies facilitate the integration of wind turbines and other variable energy sources into the energy system. These technologies include high-voltage direct current (HVDC) transmission systems, energy storage technologies, compensation units and systems for production forecasting and control of wind power plants."

\section{International $R \& D$ and plans}

The European Commission has supported wind power by sponsoring international research co-operation between institutes, universities and equipment manufac- turers. In the next phase of development, Commission policy seems to be to support networking between centres of excellence in Europe. A Green Paper from the Commission stresses that to improve Europe's energy position it is important to exploit new national and regional energy sources, including wind energy. ${ }^{53}$

The implementation of the Kyoto Protocol will also form a good basis for further expansion of wind energy and the associated R\&D. ${ }^{54}$ The IEA supports worldwide cooperation, and has recently issued a report on the longterm R\&D needs of wind energy. ${ }^{55}$

Although the growing wind energy industry is increasingly able to support its own R\&D costs, generic longterm research and research of common interest for society and industry still needs public support. Suitable topics for this research are:

- better understanding of the nature of wind, particularly in complex terrain and offshore;

- control systems for large-scale integration of wind turbines into the electricity supply grid;

- interaction with other energy sources;

- improving methods and standards for optimising turbine design;

- predicting the performance of turbines built with new materials;

- combined simulation and test methods for very large turbines; and

- ways to ensure that wind energy is planned with due regard to the environment and people.

Denmark has taken part in the IEA's R\&D Wind international co-operation programme since its establishment. To date, this participation has been financed mainly by the Danish Energy Agency. All the IEA countries participating in R\&D Wind are supporting the programme through national and regional R\&D schemes.

It is notable that while most IEA countries report unchanged or increasing national wind R\&D budgets for 2002, Denmark has reduced its national wind energy research programme dramatically.

An important way to remove trade barriers and disseminate research results is to establish international standards for wind technology. Both national and European R\&D programmes have supported this approach, and Denmark places a high priority on active participation in new standards through the IEC and CEN/CENELEC.

The Danish research community - Risø, universities, research centres, power utilities and manufacturing industry - participates in the EU's research and technology development (RTD) programmes. In particular, testing and certification of wind turbines is an important Risø activity. ${ }^{56}$

The EU's research strategy calls for larger research consortia for the Sixth Framework Programme. To strengthen its competence in all aspects of offshore wind turbine development, Risø has recently formed a consor- 
tium with the Technical University of Copenhagen, Aalborg University and DHI (the Danish Hydraulic Institute)..$^{57}$

\section{Implications for Danish, European and global energy systems of the successful development of wind energy}

No other country approaches Denmark's use of wind energy to provide around $17 \%$ of its total electricity demand. Danish experience in managing such a high proportion of wind energy is therefore unique.

The overall conclusion is that wind energy on the Danish scale can be successfully integrated into the existing energy network..$^{58}$ On the downside, the utility companies have complained about over-production of wind energy under certain conditions, forcing them to sell surplus electricity at low rates. A number of studies have created models to help integrate wind power with existing power stations and transmission systems..$^{59601}$

The Wind Force 10 target of $10 \%$ wind power globally by 2020 may be too optimistic, but $10 \%$ wind power in the $\mathrm{EU}$ by the same date seems too cautious.

As the EC's Annual Energy Review ${ }^{62}$ says, it is a big challenge to change EU energy policy so that energy imports, currently at 50\% and growing, are reduced or at least stabilised. If no change is made, the forecast is for $70 \%$ imported energy by 2030 .

A radical change, however, will require government support for as long as wind energy technology is not fully competitive. Danish government figures ${ }^{63}$ assume that Danish wind turbine manufacturers will move most of their production to other countries but keep their knowledge bases in Denmark. The present policy of reducing government support for R\&D, however, could force manufacturers to move even their R\&D abroad.

The IEA report on long-term research ${ }^{64}$ recommends priorities for future development:

"The challenge is to try to find those revolutionary steps that can be taken to further improve wind turbine technology. For example, in large-scale integration of wind generation into the electric grid, incorporating wind forecasting and co-ordinating grid interaction with other energy sources could speed up the deployment of wind energy."

"In addition to challenges associated with the integration of the technology to produce electricity, wind energy could be used to produce other energy carriers such as hydrogen. Wind energy technology has traditionally been used in producing electricity and will be continuing to do so in the future. But, innovative concepts in hybrid systems and storage techniques may benefit other sectors of the economy, e.g. in transport both on land and in the air."

"In the energy system, wind power is a major international instrument for meeting environmental goals and meeting greenhouse gas reduction targets. Integrated energy systems with distributed generation have been developed, which accommodate the fluctuating production from most renewable energy sources. The wind power industry has become a truly international business, where the industry has reached a social importance comparable with the aeronautical industry or the automobile industry. A new engineering/scientific field to support the industry, comprising both research and education, has been established analogous to "aeronautical engineering'." 


\section{Indicators for the wind energy technology}

\section{口 Onshore $\quad$ Offshore}

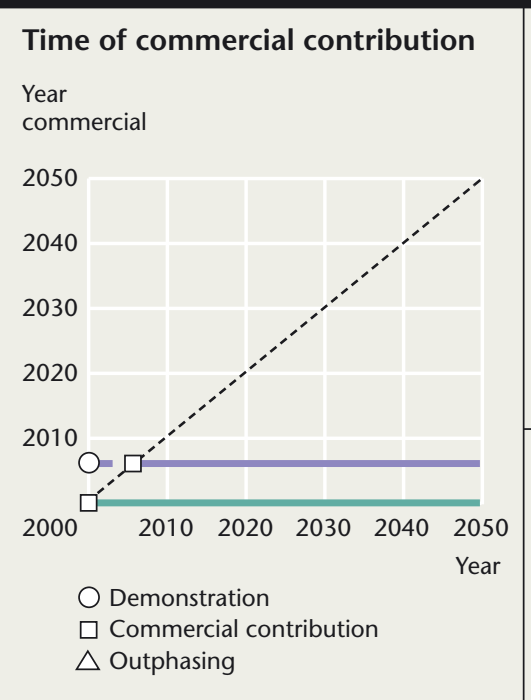

Market potential

Applications

Costs 2002

\section{$\mathrm{CO}_{2}$ re \\ Emission}

reduction

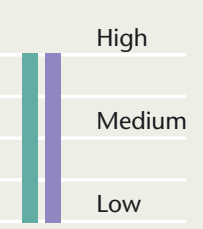

\section{tential}

Expected impact

on energy system in 2030
.

act

\section{Needed investments}

In basic and applied research

In development and demonstration

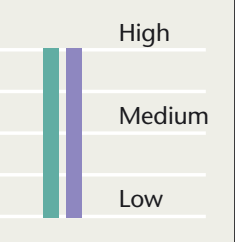

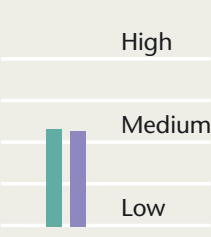

High

Low

The challenge is to try to find those revolutionary steps that can be taken to further improve wind turbine technology. For example, in large-scale integration of wind generation into the electric grid, incorporating wind forecasting and co-ordinating grid interaction with other energy scources could speed up the deployment of wind energy. Wind energy technology has traditionally been used in producing electricity and will be continuing to do so in the future. But, innovative concepts in hybrid systems and storage techniques may benefit other sectors of the economy, e.g. in transport both on land and in the air.

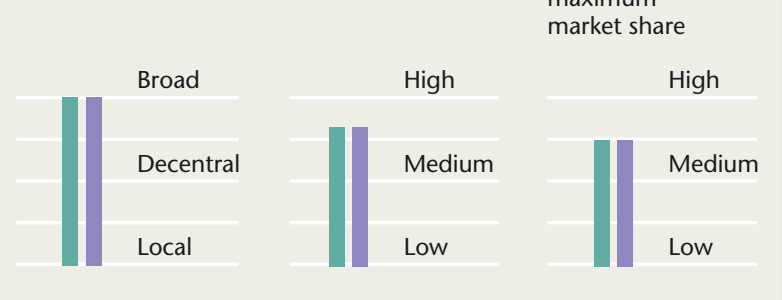

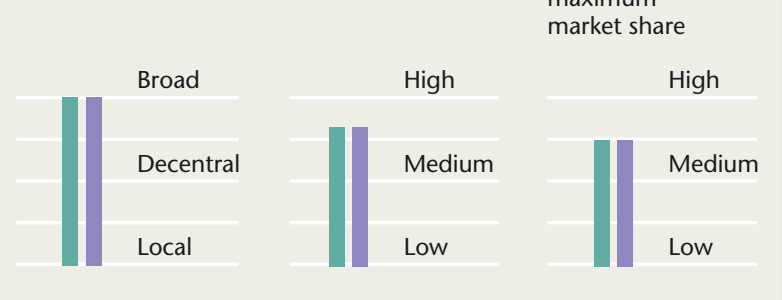

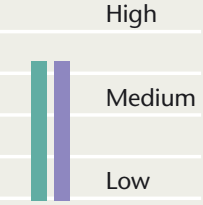

\section{Risø wind energy R\&D}

Risø performs a broad, multidisciplinary research in the area of wind energy, primarily in the Wind Energy Department in cooperation with other research departments at Risø.

Wind resource estimation at Risø is mainly concerned with developing flow models to provide better results in complex terrain, offshore and at heights above $100 \mathrm{~m}$. Wind engineering also faces the challenges of more accurate turbulence modelling, better estimates of extreme winds and better understanding of the behaviour of the wind profile.

In close co-operation with the Technical University of Denmark (DTU), Risø researchers have developed a computer model often described as a first-generation numerical wind tunnel. The Risø and DTU researchers are now extending their model with the aim of including the coupling between the flow around the wind turbine with the structural behavior of the rotor. This will eventually allow the researchers to investigate phenomenas as edge-wise vibrations and large deflections of the blades.

Risø research into wind energy, wind loads and safety aims to develop the reliable design methods and precise certification rules needed for

\section{Prospects in Denmark}

\begin{tabular}{lll}
$\begin{array}{l}\text { For undertaking } \\
\text { the necessary } \\
\text { research }\end{array}$ & $\begin{array}{l}\text { For industrial } \\
\text { production }\end{array}$ & For export \\
High & High & High \\
\hline Medium & Medium & Medium \\
\hline Low & Low & Low \\
\hline
\end{tabular}




\section{Fuel cells}

FINN WILLY POULSEN, MATERIALS RESEARCH DEPARTMENT, RIS $\varnothing$

\section{General operating principles}

A fuel cell is a continuous system for converting chemical energy into electricity, like a battery that never runs down. Over the past seven decades scientists have discovered and studied many different types of fuel cells (Table 5).

In particular, alkaline and polymer fuel cells have been used in space technology, and polymer fuel cells are emerging in zero-emission cars.

Individual fuel cells are assembled into a "stack" to provide higher voltages for practical applications. Each stack typically has a power rating of $5-200 \mathrm{~kW}$, a size range in which conventional electricity generating systems tend to be expensive and inefficient. Fuel cells are therefore suitable for small as well as large generating plants.

Regardless of type, fuel cells have several features in common. Unlike internal or external combustion engines, fuel cells are not limited in efficiency by the Carnot, Rankine or other thermodynamic cycles. Fuel cells can convert chemical energy into electricity with efficiencies of $50-60 \%$ or higher, compared to a maximum of $40 \%$ in internal combustion engines.

Practical fuel cells use hydrogen, methanol, carbon monoxide or methane as the fuel at the anode. At the cathode oxygen from the atmosphere is used as the oxidant. Methane fuel cells generally use natural gas that has been partly or fully reformed (converted into carbon monoxide and hydrogen) or partly oxidised. Light gasoline fractions can also be used as fuel after they have been cracked or reformed.

The exhaust from a fuel cell is water vapour, when the fuel is hydrogen, or a mixture of water vapour and $\mathrm{CO}_{2}$ when the fuel is methanol, natural gas or reformed higher hydrocarbons. Due to their higher efficiency, fuel cells emit less $\mathrm{CO}_{2}$ per $\mathrm{kWh}$ of electricity than generators driven by diesel engines, gas turbines or steam turbines. The exhaust gases from high-temperature fuel cells (MCFCs and SOFCs) can themselves be used to drive gas or steam turbines. Such double- or triple-cycle generation systems can achieve overall efficiencies above $80 \%$. Foreseeable application areas for fuel cells (with typical fuel cell types and power ratings in brackets) are:

- Portable electronics (DMFC) (1 W-200 W);

- Domestic heat and power (PEM, SOFC) (5-200 kW);

- Electric road vehicles (PEM) (50-200 kW);

- Ships (>MW);

- Power stations (SOFC) (>>MW).

The last four of these applications will have massive beneficial economic and environmental impacts, including the creation of new high-tech industries. Forty years from now, nations with access to natural gas may have completely replaced their conventional CHP installations with solid oxide fuel cells.

The main problems to be overcome in all fuel cell R\&D programmes are increasing the durability of fuel cells, increasing performance and lowering fabrication costs. Fuel cells operated in reverse mode, as electrolysers, will play an important role in the future "hydrogen society" (Chapter 7.3).

\section{Danish activities}

Denmark is now one of the European leaders in SOFC fuel cell research. Two Danish universities carry out fundamental studies of fuel cell materials. University of Southern Denmark is working on SOFC materials and polymer membrane materials for direct methanol fuel cells. Researchers at DTU are studying phosphoric acid fuel cells, composite electrolyte materials for intermediate temperatures $\left(150-300^{\circ} \mathrm{C}\right)$ and SOFC materials. Risø and the above mentioned academic institutions are part of a Nordic network for "Electrochemical Energy Conversion" sponsored by the Nordic Energy Research Programme.

The Danish company IRD A/S in Svendborg is active in polymer fuel cells and a partner in various European electric vehicle projects. The Danish catalyst and engineering company Haldor Topsøe A/S, Ravnholm, has supported external SOFC research for a number of years and now has a big in-house research project on SOFCs.

\section{European level}

Molten carbonate fuel cells $\left(650^{\circ} \mathrm{C}\right)$ were studied intensively in the Netherlands and Italy during the 1980s and 1990s, but serious problems with corrosion, dissolution of the cathode and electrolyte creep seem not to have been solved.

Alkaline and phosphoric acid fuel cells are more or less fully mature, but their performance and price cannot compete with the newer polymer fuel cells and SOFCs. Polymer fuel cells and SOFCs are therefore the main targets for current European and global R\&D. The leading researchers include Siemens-Westinghouse (Germany), Sultzer (Switzerland), De Nora (Italy) and Rolls-Royce (UK). Sultzer is expecting to install up to 1000 SultzerHexis SOFC units, each rated at a few kW, in German, Swiss and Austrian households within the next three years. In the car industry, Daimler-Ballard has invested over US\$ 1000 million, mainly in polymer fuel cells, over the period 1998-2002.

Both Nordic ${ }^{65}$ and European ${ }^{66}$ expert groups strongly recommend more emphasis on fuel cell research. To 
Table 5: The main types of fuel cell, their acronyms and basic characteristics.

\begin{tabular}{|c|c|c|c|c|c|}
\hline Acronym & AFC & PAFC & SPFC/ PEMFC & MCFC & SOFC \\
\hline Full name & Alkaline & Phosphoric acid & Polymer & Molten carbonate & Solid oxide \\
\hline Fuel & Very pure $\mathrm{H}_{2}$ & CO-free $\mathrm{H}_{2}$ & & $\mathrm{H}_{2}, \mathrm{CO}, \mathrm{CH}_{4}$ & $\mathrm{H}_{2}, \mathrm{CO}, \mathrm{CH}_{4}$ \\
\hline Electrolyte & $\mathrm{KOH}$ solution & $\mathrm{H}_{3} \mathrm{PO}_{4}$ solution & Nafion polymer & $\begin{array}{l}\text { Molten } \\
\mathrm{Li}_{2} \mathrm{CO}_{3}+\mathrm{K}_{2} \mathrm{CO}_{3}\end{array}$ & Doped zirconia \\
\hline Electrodes & $\mathrm{Ni}$ & Graphite + platinum & Graphite + platinum & $\mathrm{Ni}, \mathrm{Ni}(\mathrm{Li}) \mathrm{O}$ & $\mathrm{Ni}$, ceramic \\
\hline Temperature & $100^{\circ} \mathrm{C}$ & $200^{\circ} \mathrm{C}$ & $100^{\circ} \mathrm{C}$ & $650^{\circ} \mathrm{C}$ & $<850^{\circ} \mathrm{C}$ \\
\hline Efficiency $(\%)^{*}$ & 40 & 40 & 40 & 60 & 60 \\
\hline Application & Space, military & CHP up to $200 \mathrm{~kW}$ & $\begin{array}{l}\text { Space, electric } \\
\text { vehicles }\end{array}$ & $\begin{array}{l}\text { CHP } \\
\text { (MW range) }\end{array}$ & $\begin{array}{l}\text { CHP } \\
\text { (kW-MW range) }\end{array}$ \\
\hline
\end{tabular}

allow Denmark to compete internationally it has been estimated by the Haldor Topsøe Company to need a minimum investment of 50 person-years/year for the next ten years. Building an SOFC factory is expected to cost more than US\$100 million.

\section{Global level}

Though fuel cell research has had its ups and downs in the past, the current consensus is that fuel cells have a bright commercial future in cars, households and the power industry.

Siemens-Westinghouse plans to deliver SOFC-based CHP units from 2003, and pressurised SOFC/gas turbine hybrid systems from 2005. The cost of installed SOFC power is expected to be US $\$ 400 / \mathrm{kW}$ once high-volume production has been reached.

It is likely that several types of fuel cells will reach commercial production, each serving a particular market such as transport, power stations or CHP on different scales. A full review of world activity in fuel cells is beyond the scope of this text; for more details see Fuel Cells Bulletin or publications from the European Fuel Cell Forum. 


\section{Indicators for the fuel cell technology}

\section{AFC (Alkaline) PAFC (Phosphoric acid) $\square$ MCFC (Molten Carbonate) 口 SOFC (Ceramic) — SPFC/PEMFC (Polymer)}

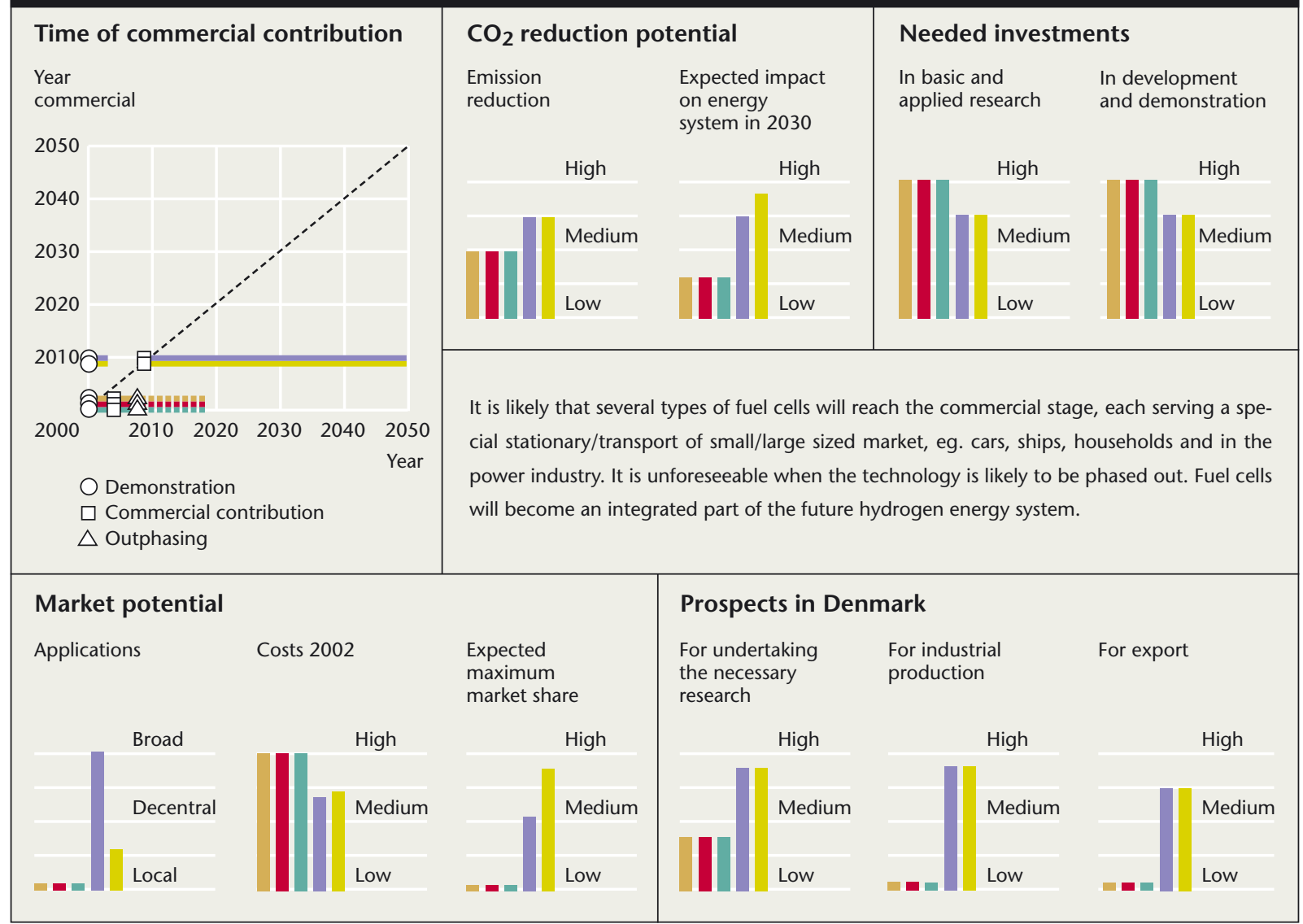

\section{SOFC fuel cell research at Risø}

Basic studies of oxygen-ion-conducting ceramics started at Risø around 1980. With support from the Danish Energy Authority, ELSAM and Elkraft, more focused research on SOFCs began in 1989. The first-generation cells were electrolyte-supported, based on tapecast yttria-stabilised zirconia. During 1995-96 a $500 \mathrm{~W}$ stack (70 cells in series) was built and tested for 2000 hours at $1000^{\circ} \mathrm{C}$.

Second-generation cells and stacks, based on thin zirconia films on anode supports have been tested by the Sultzer Company in Switzerland, and improvements to the anode-supported design are ongoing. The main issues are improved durability of the cells and stacks over many thousands of hours, and design changes, especially to the cathode, that will allow the operating temperature to be reduced to $550-600^{\circ} \mathrm{C}$.
Third-generation cells will use both new materials and new fabrication methods. Work on these has already begun, hand-in-hand with fundamental research.

SOFC R\&D at Risø is currently done in collaboration with Haldor Topsøe $A / S$, under an agreement that started in autumn 2001 and will continue until May 2006. A pilot-scale production line for anode-supported SOFCs is now in operation at Risø's Materials Research Department. Production started early in 2002, with an estimated throughput of 300 cells per day. The Risø SOFC group holds hundreds of publications ${ }^{676869}$ in international journals, and ten patents. 


\subsection{Hydrogen as an energy carrier}

ALLAN SCHRØDER PEDERSEN, MATERIALS RESEARCH DEPARTMENT, RISØ AND KAJ JØRGENSEN, SYSTEMS ANALYSIS DEPARTMENT, RIS $\varnothing$

The vision for hydrogen is as a platform for sustainable energy systems: energy-efficient and clean systems with a large proportion of renewable energy sources, or possibly future designs of nuclear reactor.

Electricity and substances such as natural gas are known as energy carriers because they allow energy to be transported easily and in some cases stored for future use. However, our existing energy carriers all have drawbacks. Electricity is in itself a clean form of energy, but it is difficult to store. Natural gas and hydrocarbon fuels are easy to store, but generate $\mathrm{CO}_{2}$ when they burn.

Hydrogen is an ideal energy carrier because it can be stored like conventional fuels, yet generates no $\mathrm{CO}_{2}$. Since hydrogen does not occur naturally in its uncombined form, it must be produced from hydrogen-rich substances such as water, hydrocarbons or biomass - this is analogous to producing electricity from fuels, nuclear reactors or solar energy.

Hydrogen can be extracted from water, and forms only water when it burns. The use of hydrogen as an energy carrier is therefore a closed cycle causing absolutely no damage to the environment.

Hydrogen can be stored underground in large quantities, in surface tanks and in cylinders for mobile applications. Although its energy density (measured in $\mathrm{kWh} / \mathrm{kg}$ ) is not as high as for fossil fuels, hydrogen is much cheaper than electric batteries as a way to store energy. Hydrogen can be burned to produce heat, or used to run fuel cells that convert chemical energy to electricity with very high efficiency.

Two applications of hydrogen as an energy carrier are particularly important: as a way to increase the flexibility of the electricity supply system, and as a transport fuel.

Renewable energy sources, particularly wind power, tend to be inherently variable and difficult to control. Energy systems with a large percentage of renewables, especially if there is also widespread use of CHP, therefore suffer from problems in matching supply with demand. By providing a way to store surplus energy, hydrogen can allow a larger fraction of renewable energy to be used while still matching supply to demand (see also Chapter 14).

As a transport fuel, the most important function of hydrogen is to encourage the use of renewable energy in this sector. In addition it can reduce city pollution even when burned in conventional internal combustion engines. Hydrogen burned in internal combustion engines can reduce city pollution and encourage the use of renewable energy in this sector. In the longer term, fuel cells burning hydrogen to power electric vehicles will make the transport sector considerably more energyefficient and cleaner than is possible with internal combustion engines.

\section{Status of the technology}

Today hydrogen is used mainly as a feedstock in the chemical and oil industries, with the overwhelming majority of hydrogen being generated on site by steam reforming of natural gas. Practical applications of hydrogen as an energy carrier are negligible, and confined mostly to research, development and demonstration projects. Outside the industrial sector, the main use of hydrogen so far has been as a fuel in the space programmes.

\section{Trends and perspectives}

A large-scale shift to hydrogen as an energy carrier will require $R \& D$ on hydrogen production, distribution, storage and use. The main challenges include technologies for:

- producing hydrogen from wind, wave and solar power, whose availability fluctuates. Electrolysis of water is a prime candidate (see also Chapter 14);

- producing hydrogen from other renewable energy sources, particularly biomass;

- using hydrogen, especially in fuel cells for stationary, mobile and portable applications;

- storing hydrogen, especially in mobile and portable applications. The criteria for mobile storage are particularly demanding. The US Department of Energy has set targets of $6.5 \%$ hydrogen by weight and $62 \mathrm{~kg} \mathrm{H}_{2} / \mathrm{m}^{3}$ for a hydrogen storage system to be industrially applicable (Figure 18);

- distributing hydrogen from producers to users, including facilities for refuelling vehicles;

- systems integration (see also Chapter 14); and

- implementing hydrogen systems.

As well as technological development we need systems analysis, especially to address the issues of power system integration and develop a fuel infrastructure for the transport sector.

These challenges are being addressed all over the world, so Danish researchers have a great deal of background on which to draw. Denmark's heavy use of wind energy, however, creates a particularly Danish need for research on hydrogen as a way to integrate renewable energy into the power system. Hydrogen storage systems, fuel cells and systems analysis are the main research targets here. 


\section{International R\&D and plans}

Increasing interest in hydrogen as an energy carrier is reflected at a European level by the European Commission's new Framework Programme for European research ${ }^{71}$ which highlights hydrogen technology as a way to promote sustainable development.

Several European countries, however, have been working on hydrogen for much longer. Germany, for example, has carried out many hydrogen projects in pure research, industrial development and demonstrations. ${ }^{72}$ The US government has run fairly extensive hydrogen R\&D programmes for many years. ${ }^{7374}$

$\mathrm{R} \& \mathrm{D}$ in the electrolysis of water is directed partly towards improving conventional electrolysis methods, based on alkaline electrolysis, and partly towards advanced technologies such as solid polymer electrolysis (SPE).

The highest electrolysis efficiency may turn out to come from high-temperature solid oxide electrolysis cells (SOECs). Reversible solid oxide fuel cells, which can be used as electrolysers, were demonstrated more than ten years ago. Their efficiency was excellent, but development stopped around 1990 because of high fabrication costs. With the improvements in SOFCs during the last decade, it may be time to look again at SOECs.

Apart from electrolysis, the main way to generate hydrogen from renewable sources is conversion of biomass by gasification or pyrolysis. A long-term possibility is photoelectrochemical cells (PECs), which produce hydrogen from sunlight, and in the even longer term there are various other interesting ways to convert sunlight into hydrogen.

Figure 18

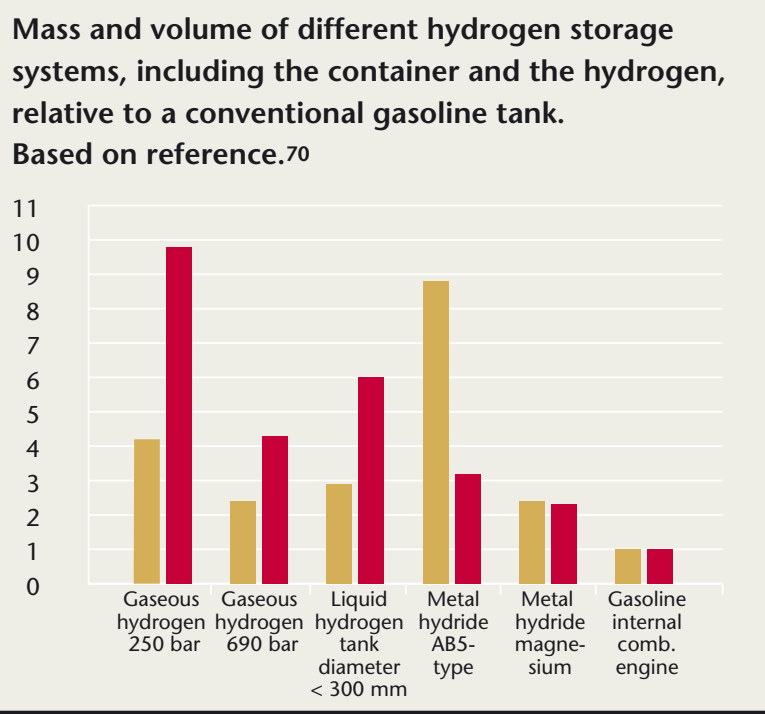

口 Mass Volume
We already have a range of different hydrogen storage options, at different levels of development, and new methods are being explored. The three main storage options are as compressed gas in lightweight pressure vessels or underground cavities, as metal hydrides, and as liquid hydrogen.

R\&D on the use of hydrogen focuses on fuel cells for stationary, mobile and portable applications, though there are other ways to use hydrogen. The two most promising options at the moment are solid polymer fuel cells, also known as proton exchange fuel cells (PEMFCs), and solid oxide fuel cells (SOFCs). PEMFCs are well advanced and are the prime candidate for mobile applications. SOFCs lag a little way behind in development, but may compete with PEMFCs for stationary applications (see also Chapter 6).

Internationally, relatively few systems analysis projects cover the integration of hydrogen-based renewable energy into the electricity supply system. Many "solar hydrogen" projects are stand-alone systems with respect to the grid, or are perceived as such. In Denmark, standalone power generation is of limited interest because of the extensive reach and high quality of the grid. Accordingly, researchers at Risø and Roskilde University Centre have been carrying out their own systems analysis work. A key issue in the use of hydrogen is to make the technology cost-competitive with existing systems by reducing costs or increasing taxes. There is also a critical "chicken-and-egg" situation to be faced during the transition to a hydrogen economy, notably in the transport sector. Without encouragement, motorists will not buy hydrogen cars for which there are no filling stations, and energy companies will not build filling stations for which there are no cars.

\section{Implications for Danish and international energy systems}

Denmark has a particularly urgent need for a flexible power supply system due to its relatively high (and rising) percentage of wind power and an extraordinarily high share of CHP. A recent report from the Danish Energy Agency ${ }^{75}$ addresses the problem of integrating renewable energy in the Danish energy system. As Figure 19 shows, the report does not anticipate significant technical or economic problems until after 2010.

If new integration technologies are to be identified and developed in time, however, R\&D work must start soon. Much can be done simply by analysing the problem in detail and optimising current technologies, such as exchanging electricity with neighbouring countries or geographical regions, and "intelligent" price communication between suppliers and consumers. In the longer term, greater use of renewable energy will only be possible if we can store electricity in large quantities, and that means using hydrogen.

Wind power is growing strongly in many countries 


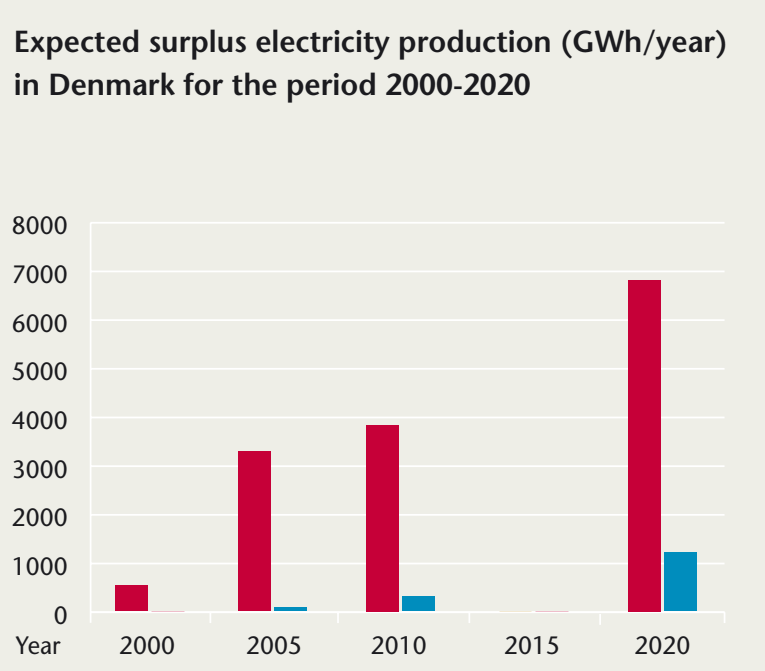

Data for 2015 are not available. The red bars indicate surplus production that can be handled by export and other means.

The blue bars show surplus production that cannot be properly handled using current technology and systems.
Figure 19 besides Denmark, so hydrogen technologies and the know-how of systems integration will find a ready international market. In fact, hydrogen can be a cheaper and more energy-efficient medium than electricity for the long-distance transmission of energy, ${ }^{76}$ especially for large energy quantities, so its international prospects are good.

\section{Further references}

Further references for this chapter can be found in Chapter 9 , References, note. ${ }^{778798081}$ 


\section{Indicators for the hydrogen energy carrier technology}

\section{Hydrogen energy carrier technology}

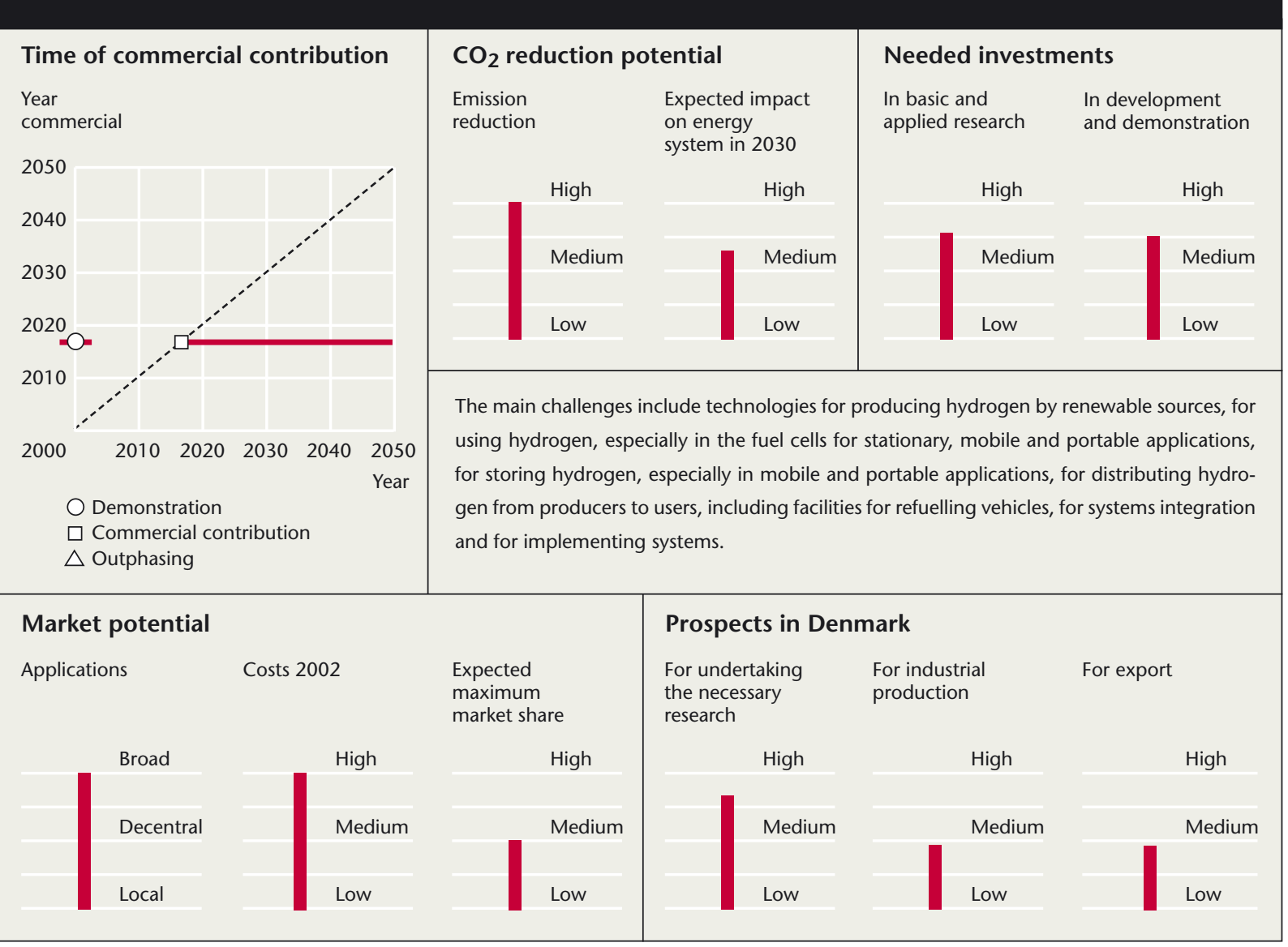

\section{Hydrogen energy systems research at Risø}

Scientists in the Materials Research Department at Risø are working to develop new and effective storage technologies for hydrogen. In the past, much of this work has been on the direct formation of magnesium hydride, one of the most hydrogen-dense compounds known to be able to store hydrogen in a reversible way.

The drawback of magnesium hydride is that it needs high temperatures to allow hydrogen to be taken up and desorbed at realistic speeds. Interest at Risø has therefore moved to other types of metal hydride.

We have concentrated on nanocrystalline metals prepared using ball mills. Our aim is to alter the properties of magnesium alloy systems by adding other, preferably light, elements. Aluminium, for instance, destabilises the hydride, allowing it to work effectively at lower temperatures and pressures. Other elements act as catalysts, speeding up hydrogen uptake or desorption and again allowing the hydride to work at lower temperatures and pressures.

The Systems Analysis Department is examining the technical and economic feasibility of hydrogen energy as well as the effects of hydrogen technologies on the energy system.

Projects include generic systems analyses covering complete energy systems, and more specific studies of power system integration and use of hydrogen in the transport sector. Several of these projects have investigated different scenarios for the large-scale introduction of hydrogen energy. 


\section{Photovoltaics}

KELD WEST AND FREDERIK KREBS, THE DANISH POLYMER CENTRE, RISØ

Photovoltaics (PV) or "solar cells" are devices that convert solar energy directly into electricity. They are the most cost-efficient choice for energy production in remote areas with little or no infrastructure, including rural households in developing countries.

Centralised power generation by PV systems is presently still more than ten times more expensive in economic terms than conventional sources of electricity. Nevertheless, generating power on a small scale, where and when it is needed, can be worth the premium even in urban areas.

Decentralised generation is feasible because PV systems require no system operators, cause no pollution and are noiseless, and because the cost per kWh of PV electricity is relatively insensitive to the scale of the installation. Distributed power generation can improve overall reliability by reducing loads on the grid, and gives consumers more control over energy costs in a time where deregulation has left the utility companies with a flawed image. The main incentive for stepping up PV power generation is that it constitutes a clean energy source that can reduce the consumption of fossil fuels.

Figure 21: The points show PV module prices for cumulative worldwide module sales in successive years versus the total accumulated shipment. The straight line corresponds to a $20 \%$ fall in cost for each doubling of cumulative production. Source: R.H. Williams, Facilitating Widespread Deployment of Wind and Photovoltaic Technologies, February 2002, www.energyfoundation.org.

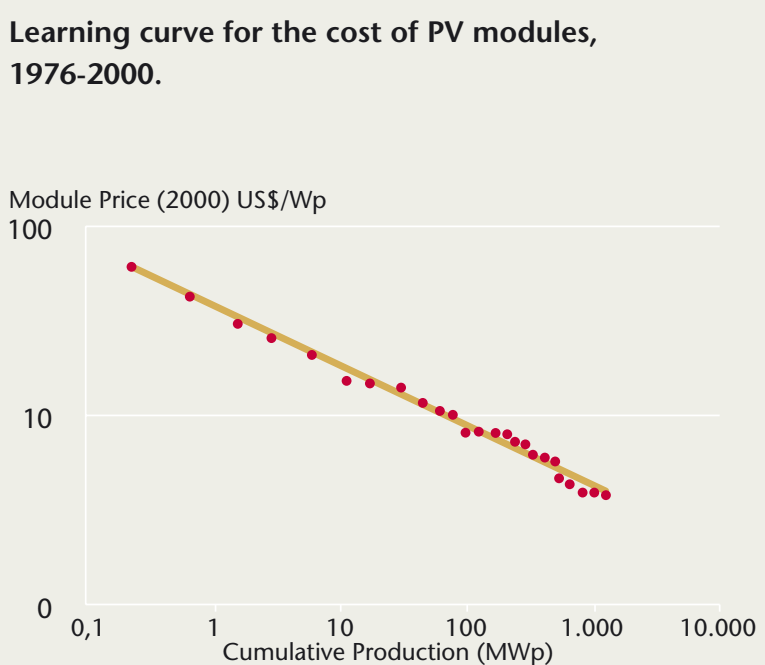

The straight line corresponds to a $20 \%$ fall in cost for each doubling of cumulative production.
Solar photovoltaics are by now the second fastest growing energy source, surpassed only by wind energy. The total shipment of PV modules reached 238 peak MW in 2000, a $42 \%$ increase over $1999 .{ }^{82}$ At the same time the price of PV is decreasing, from an average of US\$3.94 per peak watt $\left(\mathrm{W}_{\mathrm{p}}\right)$ in 1998 to $\$ 3.62$ per $\mathrm{W}_{\mathrm{p}}$ in $1999 .{ }^{83}$ Historical data show that the price of PV decreases by $20 \%$ for each doubling of cumulative production (Figure 21). The U.S. Photovoltaic Industry Roadmap predicts a worldwide shipment approaching $18 \mathrm{GW} / \mathrm{y}$ by 2020, representing a direct market of about US\$ 27 billion and an indirect market twice that size. ${ }^{84}$ Europe's share of this market potential is uncertain. Historically, European companies took roughly one-third of the world market up to 1994, but competition is fierce, and the rapid expansion of production capacity in Japan has reduced the European share to below 20\%.

The following sections introduce the main PV technologies and outline their relative merits.

\section{Crystalline silicon}

Approximately $90 \%$ of the PV units produced today are made from crystalline silicon. In 2000 the equivalent of $103 \mathrm{MW}_{\mathrm{p}}$ was produced from monocrystalline silicon and $104 \mathrm{MW}_{\mathrm{p}}$ from polycrystalline silicon..$^{85} \mathrm{~A}$ small amount was also made from ribbon or sheet silicon.

The primary advantage of crystalline silicon is that highly efficient devices can be made with this technology. Laboratory devices with efficiencies close to $25 \%$ have been demonstrated, and the best commercial cells have now reached efficiencies of $17-18 \%$. When production quantities of higher quality float zone silicon become available, $20 \%$ efficiencies in commercial modules are expected.

Because silicon is an "indirect band" semiconductor, a relatively thick active layer of silicon is required to absorb the full solar spectrum and the wafers used to produce these cells are typically several hundred $\mu \mathrm{m}$ thick. They are machined from ingots produced in high-temperature, energy-intensive metallurgical processes, and substantial amounts of material are lost during processing.

Solar cell quality silicon is thus expensive to produce. The price of the wafers accounts for around $40 \%$ of the final module cost, and as a large part of this price is energy cost, several years of operation are required to recoup the energy used to manufacture the cells. Alternatives to silicon are III-V semiconductors like gallium arsenide, from which highly efficient (>25\%) photovoltaics have also been made. 


\section{Thin-film devices}

Thin-film devices based on amorphous silicon are less efficient than devices based on crystalline silicon, but as this technology is well suited for mass production they can potentially achieve a better price to performance ratio. With ongoing development in performance and production technology, thin-film PVs are becoming increasingly competitive with crystalline silicon, and their production volume is now $30 \mathrm{MW}_{\mathrm{p}}$ /year.

Amorphous silicon is a direct-band semiconductor characterised by a high absorption coefficient in the visible spectrum. Only a thin film $(<1 \mu \mathrm{m})$ is needed to absorb the sunlight, but even thinner layers are typically used in order to minimise recombination losses.

Thin-film cells can be deposited in a continuous process (plasma-enhanced chemical vapour deposition, PECVD) onto a flexible steel or plastic substrate, and a stackedcell approach has been developed in which multiple thin cells of different band gaps are stacked on top of each other. This has the advantage of using the solar spectrum more efficiently.

Another approach is deposition onto a textured, reflecting substrate. The light reflected from the back contact undergoes multiple internal reflections within the device, allowing weakly-absorbed light to pass through the cell many times.

The major drawback of amorphous silicon is its low efficiency, caused by recombination at unsaturated bonds in the amorphous material. Exposure to light increases the number of these defects, so the efficiency of the device decreases to a lower but stable value during the first 1000 or so hours of illumination (the Stäbler-Wronski effect). The present laboratory record for stabilised efficiency is $13 \%$, obtained from a triple-junction cell. ${ }^{86}$ Commercial modules have stabilised efficiencies of $4-8 \%$, but a stabilised commercial efficiency of $10 \%$ seems to be within reach during the next few years.

Alternatives to amorphous silicon are copper indium diselenide (CIS) and copper indium gallium diselenide (CIGS). These systems are not prone to light-induced degradation, and the very high efficiency of $16.6 \%$ has been obtained for thin-film solar modules based on CIGS. The technology for producing these modules is now close to commercialisation. ${ }^{87}$

\section{Photoelectrochemical cells}

Alternatives to classical p-n junction semiconductor PVs have been developed in recent years. One new type of PV system is the photo-electrochemical (PEC) cell, ${ }^{88}$ in which the photoexcitation occurs in an organic dye adsorbed on the surface of a nanocrystalline titanium dioxide (anatase) electrode. The excited electron is donated to the anatase conduction band, and the dye is then reduced to its initial state by electrons from a transparent counterelectrode, conveyed through a redox electrolyte.

As PEC cells can be produced without the need for high- temperature or high-vacuum processes, they are potentially much cheaper than doped semiconductor cells. Laboratory cells have shown a conversion efficiency of $10.4 \%$, which translates to $5-7 \%$ in commercial modules. One problem that has not yet been solved is to create an economic and durable encapsulation technology to increase the lifetime of PEC cells.

\section{Polymers}

Several laboratories are investigating the possibilities of high-volume, low-cost production of PV cells based on organic polymer systems. A growing number of organic semi-conductors are now known, and PV devices may be constructed by sandwiching one of these between two metals with suitable work functions, or by making organic p-n junctions similar to those of inorganic PV cells.

A major challenge in this work is that the electronic states in organic materials are much more localised than in inorganic semiconductors. The weak intramolecular forces and inherent disorder that characterise polymers cause photo-generated electron-hole pairs (excitons) to be strongly localised, increasing the chances of recombination and consequent loss of efficiency.

Only excitons generated within a few nanometres of the metal contact can be split, but hundreds of nanometres of material are needed to absorb most of the light. One way to circumvent this problem is through ultrafast photo-induced charge transfer from conjugated polymers (organic semiconductors) to $\mathrm{C}_{60}$ (buckminsterfullerene) molecules. With carefully-structured blends of these molecules, polymer solar cells with efficiencies of $2.5 \%$ have now been demonstrated. ${ }^{89}$

It is unlikely that organic PV will be able to compete with the durability of the inorganic systems in the near future, and this technology is thus not targeted for centralised power production. The versatility of plastic technology will, however, allow polymer PVs to be obtained in virtually any desired shape and in composite form with many other materials. Polymer PV cells are therefore ideally suited for incorporation into self-powered devices. Portability and reduced demands on infrastructure will be strong market drivers and when the polymer PV technology matures, it may contribute to the reduction of the consumption of fossil fuels.

\section{Outlook}

PV power generation found its first commercial use in spacecraft in the late 1950s, and is now becoming a viable energy option for terrestrial applications. PV technology is currently moving from first-generation, waferbased production to second-generation thin-film technology. This transition represents a drastic cut in the materials and energy cost associated with PV production, and so supports the continuing fall in the price per $\mathrm{kWh}$ that we have seen over several decades.

New PV technologies with an even larger potential for 
low-cost production are presently being researched, and large publicly-funded demonstration programmes in the $\mathrm{EU}$, the USA and Japan provide the market pull necessary for continued cost reduction.

When the present PV technologies mature to the stage where the cost is dominated by the constituent materials (semiconductor and encapsulation), it will be necessary to increase the efficiency in order to further reduce the cost per kWh. The outline of a third-generation PV with energy conversion efficiencies that double or triple the $15-20 \%$ range presently targeted is already envisioned..$^{90}$ In Europe, several companies see PV as an area with attractive growth potential, and energy corporations including Shell and BP are investing heavily in PV R\&D. Denmark has little tradition of producing semiconductor devices, and little research in traditional solar cells, but nevertheless Topsil has committed itself to start a Danish production of float zone silicon wafers for the PV market. These wafers are of a quality that is expected to open the gate to commercialisation of $20 \%$ efficient PV modules. A number of Danish application projects have helped develop expertise in integrating solar cells into buildings and domestic energy systems. It is not too late for Danish scientists to contribute to the development of PV power through research into future generations of solar cells.

\section{Further references}

Further references for this chapter can be found in Chapter 9, References, note. ${ }^{91}$ 


\section{Indicators for the photovoltaics technology}

\section{Crystaline Silicon (CrS) $\quad$ Thin Film (TF) $\quad$ P Photoelectrochemical (PeC) $\quad$ Polymer Cells (PoC)}
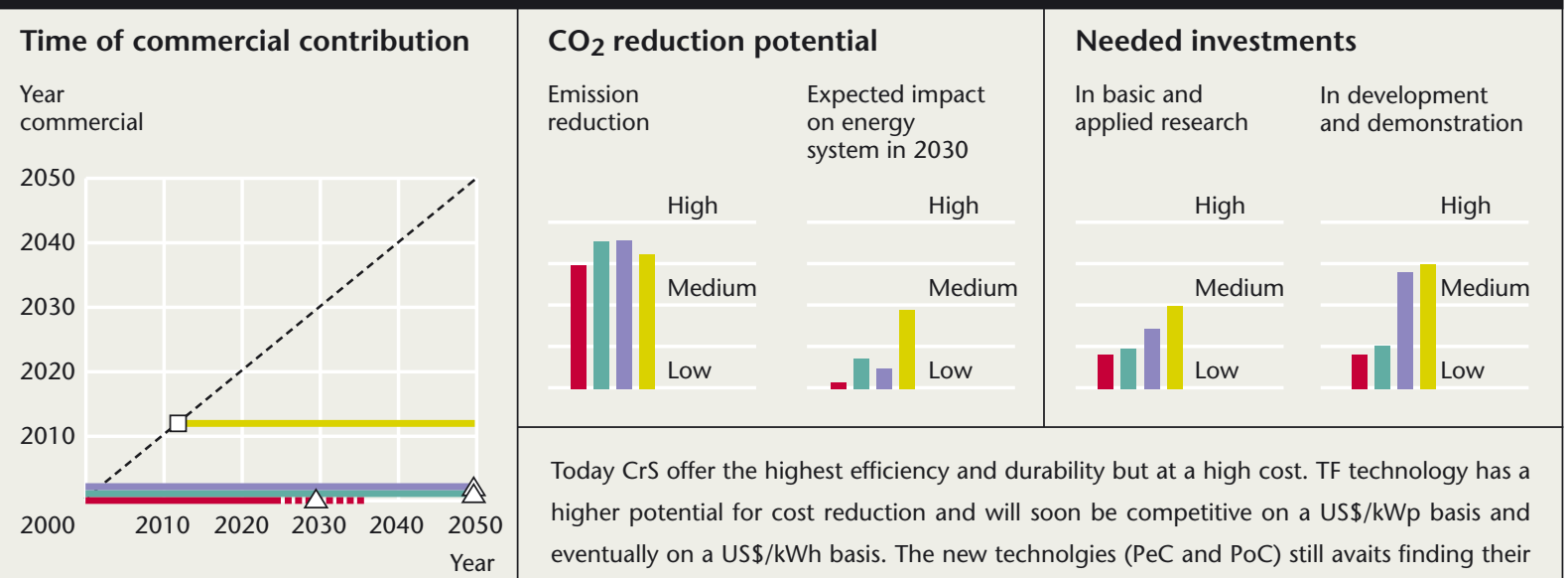

Demonstration

$\square$ Commercial contribution

$\triangle$ Outphasing
Today CrS offer the highest efficiency and durability but at a high cost. TF technology has a higher potential for cost reduction and will soon be competitive on a US\$/kWp basis and eventually on a US\$/kWh basis. The new technolgies ( $\mathrm{PeC}$ and $\mathrm{PoC}$ ) still avaits finding their market niches, but $\mathrm{PeC}$ cells have obvious advantages for integration into buildings, and $\mathrm{PoC}$ cells will be suited for off-grid use in self-powered devices.

\section{Market potential}

Applications

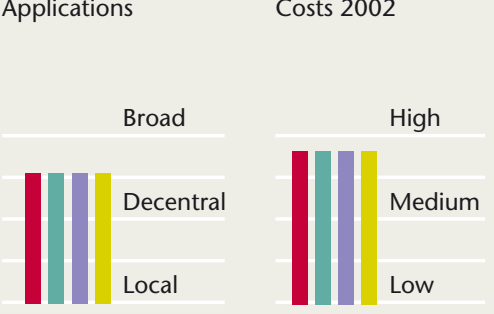

Expected maximum market share

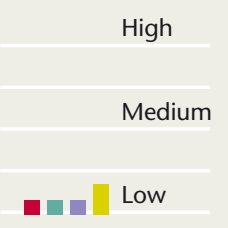

\section{Prospects in Denmark}

For undertaking the necessary

For industrial production

For export research

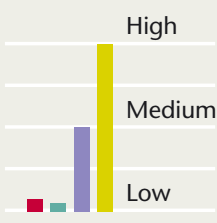

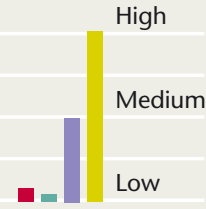

High

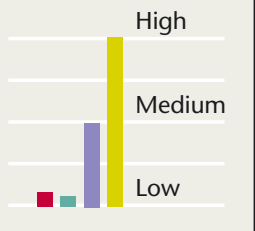

\section{Photovoltaics research at Risø}

Risø researchers are presently involved in two aspects of PV development. Both these initiatives are aimed at production technologies that fit into the Danish industrial infrastructure, which has little tradition of producing semiconductor devices.

The problem of making efficient polymer solar cells breaks down into five main areas, of which Risø scientists are working on the first four: Absorbing light; generating carriers; transporting carriers; extracting carriers; and constructing devices.

In principle, polymer chemistry provides scientists with an infinite array of possibilities. When it comes to creating polymer-based PV systems that can compete with the best inorganic systems, however, we have much to learn. Inorganic PV systems have been researched for almost 50 years and their underlying physics is now well understood. Polymer-based solar cells, in contrast, have been the subject of serious study only for the past five years. Risø's initiative on organic PV began two years ago. The results so far, for which Risø has taken out patents, centre on materials with high intrinsic carrier mobility and long carrier lifetime, and materials that are organised in such a way as to produce efficient and selective absorption of photons and subsequent generation of carriers.

Integrating photovoltaics into buildings can reduce the marginal costs of a solar cell installation. If this is to be successful, the PV devices must fulfil both the aesthetic and the functional requirements of architectural elements. In a joint effort with the Danish Technological Institute and Roskilde University, Risø is developing a glasssealed PEC cell module that can be used in façades and roofs. Risø's contribution to this work is the characterisation and modelling of PEC cell dynamics. 


\subsection{Bioenergy from waste}

SØREN K. RASMUSSEN AND JENS KOSSMANN, PLANT RESEARCH DEPARTMENT, RIS $\varnothing$

\section{Main technologies}

Biomass is any organic matter of plant or animal origin. Biomass can be burned to produce heat and electricity, but it can also be converted into biofuels.

Biofuels are generally designed as straight replacements for fuels derived from fossil sources, and are available as liquids, solids or gases. They consequently provide more flexibility than most other forms of renewable energy, and are easier to use in existing systems, markets and infrastructures.

Although its main benefit is in reducing the use of fossil fuels, bioenergy is good for the environment and society too. Unlike fossil fuels, bioenergy produces no net increase in $\mathrm{CO}_{2}$ emissions. Cultivating biomass may also create more jobs, especially local jobs, than the production of fossil fuels.

For practical purposes, biomass is usually plant material based on lignocellulose: wood from forestry, straw from crop plants such as wheat, maize and rice, or purposegrown energy crops (Table 6).

Biofuels are created from biomass using three families of conversion processes: biological, chemical and thermochemical. One well-established biological process is the production of methane (biogas) by anaerobic digestion of industrial and municipal effluent.

Bioethanol is produced by first using acids or enzymes to break down the cellulose and lignocellulose polymers into sugars, and then fermenting the sugars into ethanol with the aid of yeasts or other microorganisms.

Other biofuels are made from vegetable oils that have been chemically modified by esterification. An example is biodiesel, made by treating rapeseed oil with methanol to produce methyl esters. Biodiesel can be burned directly in diesel engines.

\section{International development}

Robert Diesel himself was the first person to use plant oils as an alternative fuel for internal combustion engines, in 1912. It was not until the oil crisis of the 1970s, however, that interest in biofuels took off.

Biodiesel is reported to release fewer solid particles than conventional diesel, and because it contains no sulphur, it does not create the $\mathrm{SO}_{2}$ which contributes to acid rain. Potentially even more important is the low level of $\mathrm{CO}_{2}$ generation associated with biodiesel, at a time when $\mathrm{CO}_{2}$ emissions are falling in every industrial sector except transport. Life-cycle studies show that biodiesel can provide at least $3.2 \mathrm{~kg} \mathrm{CO}$-equivalent reduction of greenhouse gasses per $1 \mathrm{~kg}$ biodiesel. ${ }^{92}$

The simplest thermochemical process for bioenergy is to burn wood or agricultural waste and use the resulting heat for drying, space heating or to run steam turbines. Gasification - a process of incomplete combustion - can turn biomass into a gaseous mixture of carbon monoxide and hydrogen that can be burned in space heaters, boilers, internal combustion engines or gas turbines.

Heating wood and other lignocellulose-containing plant residues in the absence of oxygen (pyrolysis) provides charcoal, pyrolysis oils that can be refined into fuels, and gases that can be burned. Bridgwater and Peacocke ${ }^{93}$ discuss how liquid fuels from pyrolysis can be used in boilers, engines and gas turbines.

The story of bioethanol shows how a process once considered to be as doubtful as the philosopher's stone has come of age commercially. ${ }^{105}$

The starting point for bioethanol is lignocellulose from plant waste, the most abundant biopolymer on earth and a material that is continuously available from farming and forestry operations. Lignocellulose is composed of the polymers cellulose and hemicellulose, tightly bound with lignin molecules, and it provides a rich source of polysaccharides for fermentation.

Thanks to new conversion technologies - the US Department of Energy, for example, has provided US\$ 14.8 million to Novozymes Biotech, Inc. to develop new enzymes to break down cellulose - bioethanol production now has a high thermodynamic efficiency and a very high net energy balance. ${ }^{94}$

All this is no use unless the resulting fuel works well, and bioethanol is ideal in many respects. It can be added directly to both gasoline and diesel fuels, in any desired proportion; in Brazil, some $40 \%$ of cars run on pure ethanol and the remainder on $22 \%$ ethanol in gasoline. In the USA, some cars run on a blend of $10 \%$ ethanol in gasoline. ${ }^{107}$

Bioethanol is " $\mathrm{CO}_{2}$-neutral": the amount of $\mathrm{CO}_{2}$ released when it burns is directly offset by the amount taken up by the plant material from which it is made. The quantity of volatile compounds released into the atmosphere from engines burning bioethanol is considerably lower than from conventional fuels, and any unburned ethanol that does enter the environment is rapidly degraded by microorganisms in the soil and surface water. ${ }^{104}$

Bioethanol can even replace the octane booster MTBE (methyl tertiary butyl ether), which was introduced as a component of gasoline to reduce air pollution but which has instead created a significant groundwater pollution problem.

\section{European perspectives}

Current EU policy is to replace $20 \%$ of fossil fuels in the 
Table 6: Resources, conversion methods and driving forces for biofuels.

\begin{tabular}{|c|c|c|}
\hline Resources & Conversion methods & Driving forces \\
\hline Wheat straw, corn stovers, rice straw, bagasse; & Biological & Waste-to-value \\
\hline Wood chips, willow, Miscanthus; & Fermentation following hydrolysis by & Bioethanol as a replacement for \\
\hline Starchy grains of maize and wheat; & enzymes or acid treatment & MTBE in gasoline \\
\hline Oil seeds from canola, sunflower, palm and soybean; & Products & Need to reduce greenhouse \\
\hline \multirow[t]{7}{*}{ Agro-industrial wastewater } & Methane (biogas), bioethanol & gas emissions \\
\hline & Chemical & \\
\hline & Esterification & \\
\hline & Products & \\
\hline & Biodiesel and other biofuels & \\
\hline & Thermochemical & \\
\hline & Combustion, gasification, pyrolysis, liquefaction & \\
\hline
\end{tabular}

transport sector with alternative fuels before 2020 . Bioethanol and biogas from renewable resources are the best options for achieving this goal.

The EU also plans to get $12 \%$ of its energy from renewable sources by 2010 , compared to the current $6 \%$. The technologies of choice in the long term are hydrogen and fuel cells, but bioenergy is a quicker way to achieve part of this goal and simultaneously solve some of the environmental problems created by agricultural waste.

\section{Bioethanol production}

Making bioethanol from lignocellulosic material begins with a pre-treatment step to separate cellulose from lignin, which is a waste product. Next, enzymes are used to break the cellulose down further to glucose, and the glucose is then fermented to ethanol using yeast. ${ }^{95}$

A newer version of this process, simultaneous saccharification and fermentation (SSF), uses a single process step for the enzymatic hydrolysis and the fermentation. To do this, enzymes are mixed with yeast and added to the process after the pre-treatment step.

\section{Outlook}

Bioethanol is still too expensive to be widely used as a fuel, but several lines of evidence suggest that costs will fall sharply in the next five years. Cheaper and more efficient enzyme cocktails are on the way, and new combinations of technologies will considerably increase process efficiencies.

Biofuels look particularly attractive if we take into account the cost of disposing of agricultural waste by conventional means. Countries such as Denmark, Germany and the Netherlands, with large animal production, face tremendous problems with manure. The ability to recover nitrogen and phosphate from this waste, and to convert the remainder into biofuel, would be a way to dispose of troublesome waste as well as a source of energy.

Another strong driving force for bioethanol is the phasing-out of MTBE in gasoline. The USA has already taken this step and is using bioethanol as a replacement. The EU is likely to take similar action within the next few years.

\section{Further references}

Further references for this chapter can be found in Chapter 9, References, notes. ${ }^{96979899100101102103106}$ 


\section{Indicators for the bioethanol technology}

\section{B Bioethanol}

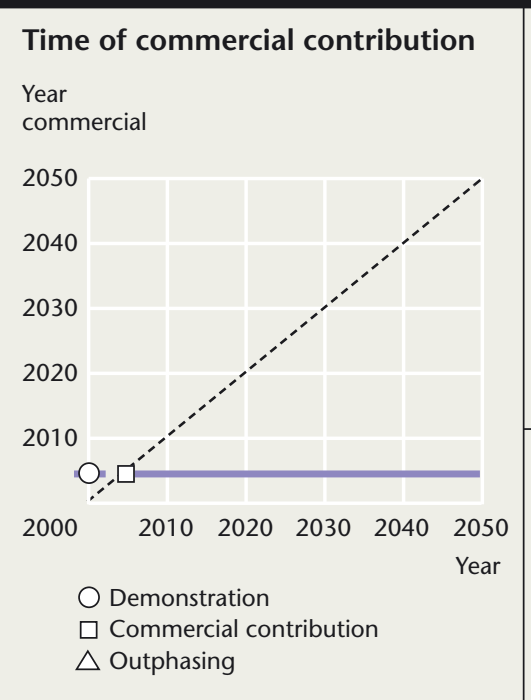

\section{Market potential}

Applications

Costs 2002

\section{Expected}

maximum

market share

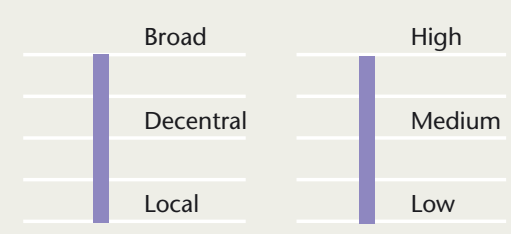

\section{$\mathrm{CO}_{2}$ re}

reduction

\section{.

.




\section{6 \\ Combustion and gasification of fossil fuels and biomass}

TAGE DRÆBYE, DRÆBYE CONSULT, AND PETER HAUGE MADSEN, WIND ENERGY DEPARTMENT, RIS $\varnothing$

The combustion and gasification of fossil fuels and biomass is a broad and fast-moving area of technology. In general, specific technologies are associated with particular fuels such as coal, natural gas and biomass, but there are also hybrid technologies.

As sustainability and environmental protection have been the main drivers in the development of these technologies, high efficiency and low emissions have been priorities in much of the R\&D and demonstration projects. Another important driver has been the risk of oil shortages, which has given priority to cleaner coal technologies and gas turbines.

Table 7 gives an overview of the technologies.

Technology "road maps" developed by the various stakeholders over the last 20 years show a strong trend towards the use of gas as the final fuel. The gas can be either natural gas or the result of gasifying solid or liquid fuels. Since the world has large reserves of coal, the main interest globally is in coal gasification. Work on advanced combustion technologies for fossil fuels, such as fluidised beds or low-emission boiler systems, is declining.

The main driver for development is environmental protection and climate policy. Fossil fuel technologies for the future are typically seen in relation to the opportunities they represent for $\mathrm{CO}_{2}$ separation and capture, and in this respect gaseous fuels are the most promising. * Emphasis on the environment also favours the use of biomass. There are promising opportunities in combustion technologies for biomass. The largest potential, however, is in gasification and gas turbine technology for biomass, and it is these areas that we describe in more detail below.

\section{Thermal gasification of biomass \\ Status}

The primary raw materials for biomass gasification are waste products from forestry and agriculture, such as straw and wood. The extent of these resources is considerable and the technology produces no net greenhouse gas emissions.

Thermal gasification is a two-step process in which solid biomass is converted thermo-chemically into a gas. In the first step, pyrolysis, the volatile components of the fuel are vaporised, leaving behind a solid material known as char. In the second step, the char is gasified by reacting it with oxygen, steam and/or hydrogen.

\footnotetext{
* One of the main reasons for this estimate is that separation of $\mathrm{CO}_{2}$ is expected to be cheaper, when fuels are in gaseous form.
}

The different gasification technologies have been tested in various scales in laboratories, small-scale prototypes and demonstration plants, and a number of them are now available commercially. Several countries, notably USA, Denmark, Germany and Finland, are involved in developing biomass gasification processes.

\section{Trends and perspectives}

The main issues to be solved in biomass gasification include long-term stability and reliability, the ability to handle a wider range of fuel properties, meeting emissions regulations and producing plants at a sufficiently low price.

Substantial R\&D effort is now being invested to solve these problems. Gasification is a technology worth perfecting, because it will give biomass the flexibility to be used in a wide range of power systems, such as gas turbines, fuel cells and reciprocating engines. Gasification will also allow the profitable use of a wide variety of biomass materials, many of which would otherwise be difficult or impossible to use as fuels.

\section{International $R \& D$ and plans}

In Denmark the reduced demand for decentralised CHP plants is the main barrier to the development of biomass gasification. As a result, companies including FLS Miljø and Babcock Vølund have scaled down their work on gasification.

In Finland and USA demonstration plants are being tested. The European Commission's Framework Programmes for R\&D have supported gasification, as do national programmes in a number of countries including the USA.

\section{Coal (and oil) gasification}

Integrated gasification combined cycle (IGCC) systems combine gasification with gas turbines and steam turbines for clean and efficient power generation. In the gasification process, solids and liquids are converted into a gas whose main components are hydrogen $\left(\mathrm{H}_{2}\right)$ and carbon monoxide (CO).

At the heart of IGCC systems are large, efficient gas turbines, the waste heat from which is used to drive steam turbines - hence the name "combined cycle".

Gasification of coal, coupled with a gas turbine, can potentially generate power as efficiently as the most upto-date conventional coal-fired plants.

Emissions from IGCC plants are much lower than those from conventional coal power plants. The gaseous fuel makes pollutant removal easier, so that, for instance, typ- 
ically more than $99 \%$ of the sulphur in the coal is captured and converted into sulphuric acid or elemental sulphur. Nitrogen oxide emissions are about one-tenth of those from a conventional power plant, and any trace elements in the coal stay with the ash.

\section{Status}

Gasification on an industrial scale began with the manufacture of town gas from coal, so the technology has been with us for more than a hundred years. For power generation, the first experimental IGCC plant was built in the early 1970s in Germany. There is currently a 250 MWe demonstration plant in Florida, USA.

IGCC plants are still at the demonstration stage, and nearly every project so far has required some form of government support. Recently, however, the worldwide commercialisation of IGCC has begun. General Electric has identified 21 IGCC projects (11 installed and 10 moving forward), representing approximately $5.1 \mathrm{GW}$ of generating capacity. An economic analysis by the US Department of Energy puts the cost of IGCC electricity at around US\$ 0.35/kWh.

IGCC technology has several different tracks, covering different gasifiers, plant sizes, coals, cleanup systems and applications.

\section{Trends and perspectives}

One of the main attractions of IGCC, besides low sul-

Table 7: Combustion and gasification technologies.

\begin{tabular}{|c|c|c|c|c|}
\hline Fuel & Technology & Technology platform & Specific technology track & Comments and brief evaluation \\
\hline \multirow[t]{6}{*}{ Solid fuels } & $\begin{array}{l}\text { Combustion } \\
\text { technologies }\end{array}$ & $\begin{array}{l}\text { Fixed-bed combustion of } \\
\text { solid fossil fuels }\end{array}$ & $\begin{array}{l}\text { Low-emission boiler systems } \\
\text { (LEBS) } \\
\text { Pulverised coal fired (PCF) plants } \\
\text { Supercritical (SC) and ultra- } \\
\text { supercritical (USC) plants }\end{array}$ & $\begin{array}{l}\text { The efficiency of the turbines is being } \\
\text { increased. The targets are still below } 55 \%\end{array}$ \\
\hline & & $\begin{array}{l}\text { Fixed-bed combustion of } \\
\text { biomass }\end{array}$ & & $\begin{array}{l}\text { Optimisation through process modelling } \\
\text { and prevention of corrosion are important } \\
\text { areas of research }\end{array}$ \\
\hline & & $\begin{array}{l}\text { Co-firing biomass and } \\
\text { solid fossil fuels }\end{array}$ & & \\
\hline & & $\begin{array}{l}\text { Fluidised-bed combustion } \\
\text { (FBC) }\end{array}$ & $\begin{array}{l}\text { Pressurised } \mathrm{FBC} \\
\text { Circulating } \mathrm{FBC} \\
\text { Bubbling } \mathrm{FBC}\end{array}$ & $\begin{array}{l}\text { In general the development of FBC has } \\
\text { been slow. PFBC is likely to fade out }{ }^{112}\end{array}$ \\
\hline & $\begin{array}{l}\text { Thermal } \\
\text { gasification } \\
\text { technologies }\end{array}$ & Biomass & $\begin{array}{l}\text { Updraught reactor technology } \\
\text { Downdraught reactor technology } \\
\text { Low-temperature (LT) circulating } \\
\text { fluidised bed }\end{array}$ & $\begin{array}{l}\text { Single-reactor technologies } \\
\text { Two-reactor technologies }\end{array}$ \\
\hline & & Solid fossil fuels & $\begin{array}{l}\text { Advanced gasification com- } \\
\text { bustion (AGCC) (DOE Vision 21) } \\
\text { Integrated gasification combined } \\
\text { cycle (IGCC) }\end{array}$ & $\begin{array}{l}\text { Gasification of coal, steam reaction to } \\
\text { create hydrogen, sequestration of } \mathrm{CO}_{2} \text { from } \\
\text { the atmosphere } \\
\text { Fluidised bed coal gasification, sulphur } \\
\text { removal, combined cycle gas com- } \\
\text { bustion (a number of pilot projects among } \\
\text { others Cool Water, California) }\end{array}$ \\
\hline Liquid fuels & Gas turbines & $\begin{array}{l}\text { High-efficiency/low-emission } \\
\text { gas turbines }\end{array}$ & $\begin{array}{l}\text { Integrated reformer combined } \\
\text { cycle (IRCC) } \\
\text { Post-combustion decarbonisation } \\
\text { Gas combustion in pure oxygen }\end{array}$ & $\begin{array}{l}\text { Can be combined with pre-combustion } \\
\text { decarbonisation (PCD) } \\
\text { A number of concepts have been developed } \\
\text { Systems are being developed by Aker } \\
\text { (Norway) (HiOx) and US Cleaner Energy } \\
\text { Systems (USA) }\end{array}$ \\
\hline
\end{tabular}


Table 8: Possible costs for $\mathrm{CO}_{2}$ capture achievable in five $\square$ and ten $\square$ years with different gas turbine technologies. Source: Carl W. Hustad. ${ }^{1{ }^{13}}$

\begin{tabular}{|c|c|c|c|c|c|c|c|c|c|c|c|c|}
\hline \multirow{2}{*}{$\begin{array}{l}\text { Concept } \\
\text { Baseline NG-CCPP }\end{array}$} & \multicolumn{2}{|c|}{$\begin{array}{l}\text { Power } \\
(\mathrm{MW})\end{array}$} & \multicolumn{2}{|c|}{$\begin{array}{c}\text { Efficiency } \\
(\%)\end{array}$} & \multicolumn{2}{|c|}{$\begin{array}{c}\text { CAPEX } \\
(U S \$ / k W)\end{array}$} & \multicolumn{2}{|c|}{$\begin{array}{c}\mathrm{COE} \\
\text { (million/kWh) }\end{array}$} & \multicolumn{2}{|c|}{$\begin{array}{c}\text { Emission } \\
\left(\text { million } \mathrm{tCO}_{2}\right)\end{array}$} & \multicolumn{2}{|c|}{$\begin{array}{c}\text { Cost } \\
\left(\mathrm{US} \$ / \mathrm{tCO}_{2}\right)\end{array}$} \\
\hline & 400 & 400 & 58 & 61 & 650 & 650 & 25 & 24 & 1,17 & 1,11 & - & - \\
\hline PDC/IRCC & 1200 & 1200 & 47 & 50 & 1200 & 1050 & 38 & 34 & 0,55 & 0,52 & 36 & 25 \\
\hline Flue gas cleaning & 400 & 1200 & 50 & 54 & 1500 & 1100 & 42 & 34 & 0,20 & 0,37 & 50 & 27 \\
\hline $\mathrm{HiOx}-\mathrm{CO}_{2}$-Recirc. & 400 & 50 & 37 & 42 & 1500 & 1200 & 47 & 40 & 0 & 0 & 40 & 34 \\
\hline CES-Steam Recirc. & 100 & 100 & 53 & (65) & 850 & (??) & 30 & (??) & 0 & 0 & 15 & (??) \\
\hline
\end{tabular}

phur and nitrogen oxide emissions, is the opportunity to capture $\mathrm{CO}_{2}$ at reasonable cost. However, the technology has three major deficiencies that need to be remedied before it becomes widely used: IGCC plants are more expensive than conventional coal-fired plants with cleanup equipment; their reliability so far has been relatively poor; and further their start-up times after a shutdown are relatively long.

Once these issues have been addressed, IGCC has the potential to take a significant share of new coal-fired power plant worldwide.

\section{International R\&D and plans}

The US Department of Energy has launched a programme (Vision 21) for the next generation of integrated gasification technology, known as Advanced Gasification Combustion (AGC). Supported by this programme, General Electric is now developing an AGC process which will convert coal into three gas streams: pure $\mathrm{H}_{2}$ to be used as fuel, pressurised $\mathrm{O}_{2}$-lean air to be used in a gas turbine, and pure $\mathrm{CO}_{2}$ ready for sequestration.

\section{Gas turbines and $\mathrm{CO}_{2}$ capture \\ Status}

The efficiency of a state-of-the-art combined cycle power plant gas turbine is around $60 \% . \mathrm{NO}_{\mathrm{x}}$ emissions are low, but the $\mathrm{CO}_{2}$ emissions are still a main problem.

\section{Trends and perspectives}

The future of gas turbine technology is closely linked to the separation and capture of $\mathrm{CO}_{2}$. A number of technology tracks are followed to address this.

One route is combustion using pure oxygen (HiOx technology and others). Oxygen combustion is being evaluated by a number of companies including Aker in Norway and Cleaner Energy Systems (CES) in the USA. The CES technology is now being tested in a planned $10 \mathrm{MW}$ gas generator at Livermore Laboratories.

Another track is pre-combustion decarbonisation (PCD), and a third is post-combustion decarbonisation (flue gas cleaning).

\section{International R\&D and plans}

In Europe, medium- and long-term research focuses on the plans in the European Commission's proposal for the 6th Framework Programme. Here the Commission proposes $\mathrm{R} \& \mathrm{D}$ on the capture and sequestration of $\mathrm{CO}_{2}$ from fossil fuel power plants. $\mathrm{CO}_{2}$ capture also has priority in US research and in a number of other national programmes, for instance in Norway.

\section{Combustion and gasification research at Risø}

Combustion research at Risø was discontinued in 1990 as a priority area. A few activities are continued, including optical measuring methods that allow measurements of many essential key parameters in combustion systems. Laser-based and advanced infrared methods are used at Risø as a diagnostic tool in the combustion research. The efforts have resulted in much better understanding of the funda- mental processes. Our activities involve measurements of flows, particle sizes, surface temperature, single/multiple particle temperatures, gas temperature, and the composition of gas and particles/ powders. Applied FTIR spectroscopy plays a major role in our present activities. 


\subsection{Advanced nuclear reactors}

BENNY MAJBORN, ERIK NONBØL AND POVL ØLGAARD, RADIATION RESEARCH DEPARTMENT, RISØ

Today about 440 nuclear power reactors with a total installed capacity of 350 GWe provide $16 \%$ of the world's electricity. Nuclear power is primarily used in the industrialised parts of the world: Europe, North America and Asia. In Western Europe, nuclear plants produce about $35 \%$ of all electricity.

In recent years the main expansion of nuclear power has been in Asia (Japan, South Korea and China). In the USA no new nuclear power reactors have been ordered since the Three Mile Island accident in 1979, though the present administration may change this trend.

Nuclear development in Europe has also slowed, particularly after the Chernobyl accident in 1986. Since the beginning of 2000 new nuclear power plants have come on stream in France, the Czech Republic, Slovakia, the Russian Federation, Brazil, India, Pakistan and Japan. Lately, the Finnish parliament has decided to construct a fifth nuclear power unit in Finland.

In recent years the trend has been to extend the operating lifetime of nuclear plants (from 30-40 to 60 years), to increase power output, to use longer operating periods and shorter shutdowns for refuelling and maintenance, and to burn a greater proportion of the fuel. All these actions help make nuclear power more competitive.

In 1999 a major new R\&D initiative began in the USA. Under the heading Generation IV, the USA started a broad long-term research programme and invited other countries to participate. Today the Generation IV International Forum (GIF) includes nine countries in addition to the USA: Argentina, Brazil, Canada, France, Japan, South Africa, South Korea, Switzerland and the UK, with more countries expected to join. The International Atomic Energy Agency (IAEA) and the Organisation for Economic Co-operation and Development Nuclear Energy Agency (OECD/NEA) are also associated with the Generation IV programme.

The aim of the GIF and the vision for Generation IV is: "The development of concepts that can be licensed, constructed, and operated in a manner that will provide a competitively priced and reliable supply of energy to the country where such systems are deployed, while satisfactorily addressing nuclear safety, waste, proliferation and public concerns".

The Generation IV programme includes R\&D on three main reactor types: advanced light water reactors with increased use of passive safety systems, high-temperature reactors and fast breeder reactors (Figure 24). The basic reactor concepts are not new, but have plenty of room for development.

The programme aims to develop the technology so that competitive plants with Generation IV reactors can be ordered after 2010 and be in operation to a significant extent by 2030. For the next decade or so, most new orders will be based on Generation III+ designs - modified versions of the nuclear power plants operating today. However, a prototype $100 \mathrm{MWe}$ high-temperature Generation IV reactor is scheduled to be operational in South Africa by 2005.

In addition to the Generation IV initiative, $R \& D$ work on high-temperature reactors is taking place within the European Commission's 5th Framework Programme with participants from a number of countries.

In Russia, economic problems have slowed nuclear development for several years, but lately the Russian government has stated that this situation will change. Work on improved versions of Russian fast reactors, for example, is now in progress.

So far the tendency has been to build nuclear power plants with steadily increasing power levels to benefit from the economic advantages of scale. In recent years, however, interest in smaller, modular units has increased. The advantage of these plants is that most of the construction work takes place in factories, with only a small part done at the site, and this can significantly reduce both construction time and indirect capital cost. With the advanced and simplified reactor designs on the drawing board today, nuclear power stations operated as base-load units should be competitive with fossil-fuel plants, especially if several plants are ordered at the same time.

Compared to fossil-fuel power plants, nuclear power plants have low fuel costs and high capital costs. The capital costs depend not only on the construction cost of the plant, but also on its capacity factor, interest rates, depreciation time and construction time. The competitiveness of nuclear power depends on all these factors, which vary from country to country.

The competitiveness of nuclear power also depends on the cost of fossil fuels and the need to reduce $\mathrm{CO}_{2}$ emissions. If $\mathrm{CO}_{2}$ emissions are to be reduced significantly, nuclear power can make an important contribution to the large-scale and economic replacement of fossil-fuel plants.

In the USA, interest in the greater use of nuclear power has increased strongly in the past two years. The factors behind this are improved performance figures for the country's operating nuclear plants, and higher prices for natural gas.

The Generation IV programme includes three main research areas: light water reactorss, high-temperature reactors and fast breeder reactors. 
The programme also promotes the examination of alternative fuel cycles that could significantly reduce the amount of waste, and the development of nuclearderived products besides electricity. One example of the latter is the large-scale production of hydrogen as a transport fuel.

For light water reactors the main developments planned are:

- passive safety systems based on the laws of nature, to reduce the need for human intervention in an emergency;

- simpler, cheaper systems, with shorter construction times;

- boiling water reactors (BWRs) with natural circulation of all coolant;

- pressurised water reactors (PWRs) with supercritical steam as the coolant and moderator;

- PWRs of integral design (all parts of the primary circuit inside the pressure vessel); and

- long-lasting cores (5-10 years) to reduce the volume of spent fuel.

For high-temperature reactors, development focuses mainly on so-called pebble-bed reactors. In this design the fuel is enclosed in billiard-ball-sized graphite balls, each containing at its centre around 15,000 small spheres of uranium oxide $\left(\mathrm{UO}_{2}\right)$ surrounded by layers of dense graphite. The reactor may contain hundreds of thousands of these fuel balls, inside a steel pressure vessel surrounded by a reflector of graphite blocks. In addition, about a hundred thousand unfuelled graphite balls are loaded into the core to control its temperature distri- bution by spacing out the hot fuel balls. Since the balls contain only refractory materials, they can tolerate very high temperatures. The coolant is helium. New fuel is added at the top and burned fuel is taken out at the bottom of the core.

The main advantages of high-temperature reactors are:

- high thermal efficiency, because the helium is fed directly into a gas turbine/generator system;

- the reactor temperature $\left(800^{\circ} \mathrm{C}\right)$ is high enough to produce hydrogen and methane, and for other chemical processes;

- the pebble bed design implies less excess reactivity during operation, and the materials can tolerate very high temperatures. This means no risk of destructive criticality or loss-of-coolant accidents;

- the inertness of helium avoids any interaction between the coolant and other materials in the reactor or turbines.

Nuclear plants can produce hydrogen by electrolysing water or using heat to drive chemical reactions. Examples of the latter include coal gasification, steam reforming of methane and pyrolysis of biomass. In principle, any power station can form a source of hydrogen, but high-temperature nuclear reactors are especially suitable for efficient hydrogen production with low emissions.

Most nuclear reactor designs can only use around $1 \%$ of the natural uranium needed to produce their fuel before the fuel needs to be reprocessed. Fast breeder reactors have the unique ability to burn all the natural uranium or thorium present in the fuel. The main developments in fast breeder reactors are:

Figure 24

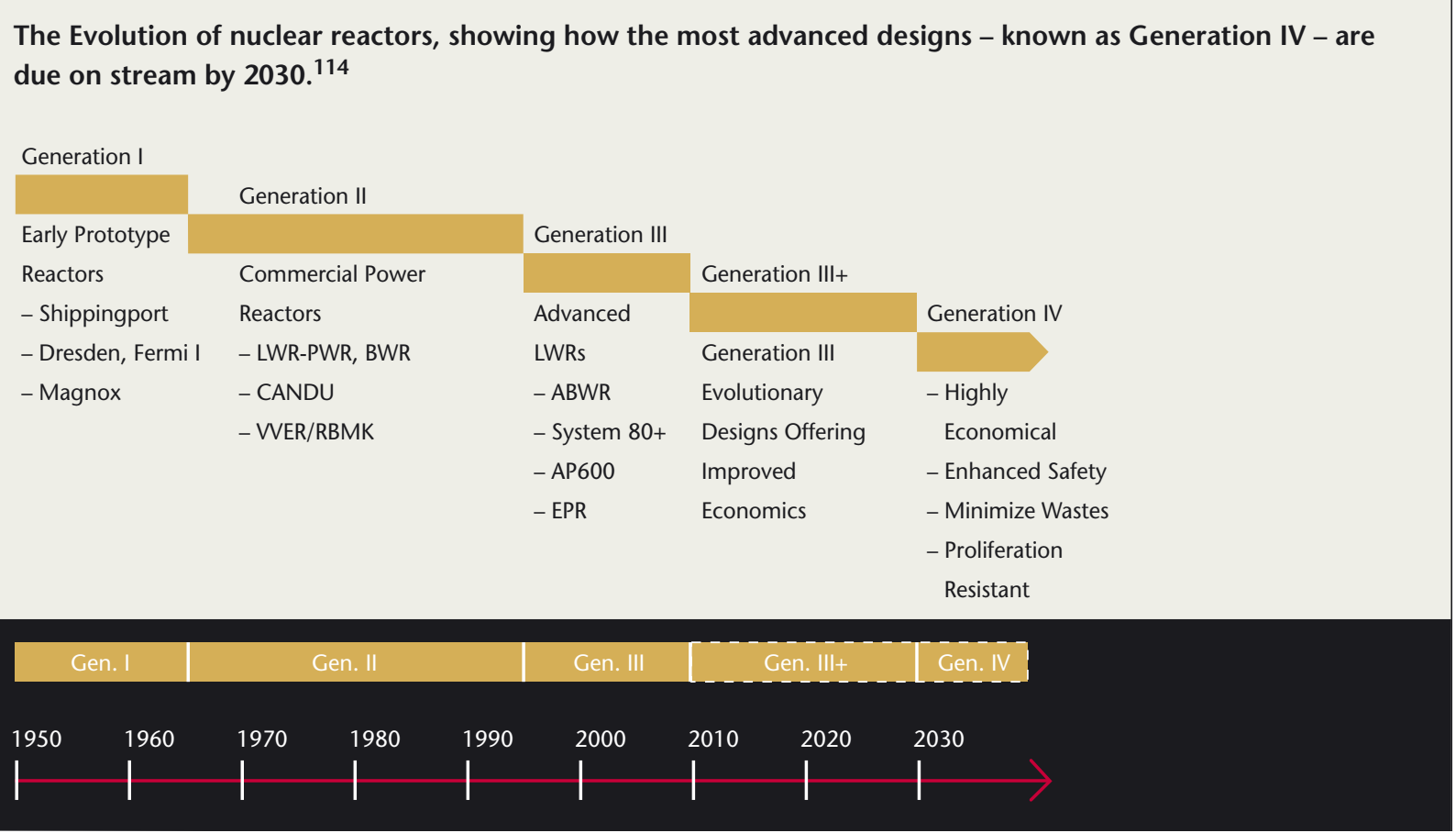


- the use of molten bismuth and lead (Bi-Pb) as a coolant instead of molten sodium. Unlike sodium, $\mathrm{Bi}-\mathrm{Pb}$ coolant does not react violently with water and does not produce highly-corrosive sodium hydroxide in the event of a leak in the steam generator. Bi-Pb coolant has been used in Soviet nuclear submarines;

- the use of metallic fuel instead of oxides, with on-site electro-metallurgical fuel reprocessing. In contrast to conventional reprocessing, this technique removes only part of the fission products, and does not produce pure plutonium. This makes it harder to use the reactor and its associated reprocessing system to generate plutonium for nuclear weapons;

- development of fast fission systems to transmute longlived transuranic nuclides into products with shorter half-lives.

The front end of the nuclear fuel cycle has a global market, while the back end remains essentially a national affair. Some countries reprocess their spent fuel and recycle the fissile materials, and others prefer simply to dispose of the spent fuel.

The two options create different amounts of waste for final disposal. If spent fuel is reprocessed, the high-level radioactive waste consists mainly of fission products and transuranic elements.

Almost all the fission products will decay within 500 years, but a few are much longer-lived. In principle, fission products with long half-lives can be transformed into nuclides with shorter half-lives through neutron capture in reactors. However, this process may require expensive and complicated isotope separation (partitioning) to avoid producing new fission products with long half-lives.

The transuranic elements in spent fuel are longer-lived, so they present a significant problem for disposal. Fast reactors, however, can dispose of transuranic elements by burning them.

Research on the fuel cycle includes better use of nuclear fuel, alternative fuel cycles based on materials such as thorium, partitioning and transmutation. Various systems are being considered to optimise transmutation. As well as using existing reactor types, in particular fast reactors, some countries have shown interest in acceleratordriven systems.

Underground disposal facilities in rock types such as clay, granite and salt have been proposed for the ultimate disposal of long-lived high-level waste. Designs have now reached the point where nuclear and geological experts are confident of their safety, but the general population has not reached the same conclusion.

Although spent nuclear fuel and radioactive waste can be held in "temporary" storage for many years, full use of nuclear power requires social consensus on the building of final repositories. In a few countries, notably Finland and Sweden, final repositories are likely to be established within the next decade.

\section{Further references}

Further references for this chapter can be found in Chapter 9, References, notes. ${ }^{115} 116117118119120121122123124125126127128$ 


\section{Indicators for the nuclear power technology}

\section{Generation III+ $\quad$ Generation IV}

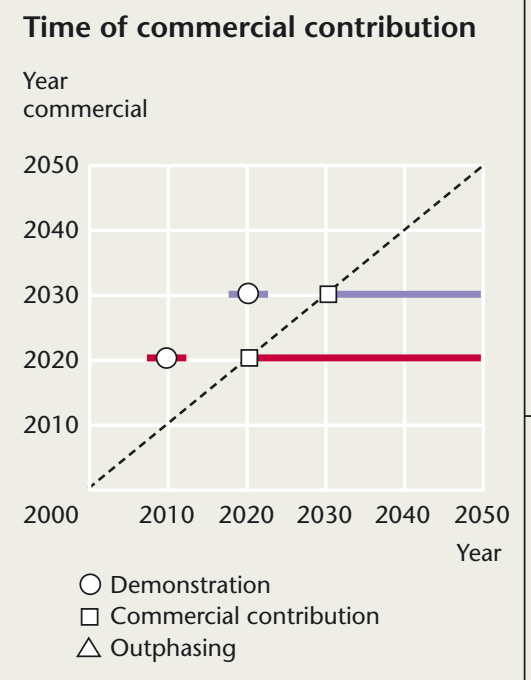

Time of commercial contribution

Year

commercial

2040

2030

2020

10

\section{$\mathrm{CO}_{2}$ reduction potential}

Emission

reduction

on energy system in

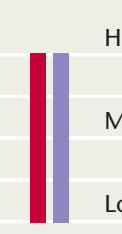

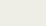

Medium

Low

For the next decade or so, most new orders will be based on Generation III+ designs - modified versions of the nuclear power plants operating today. However, a prototype $100 \mathrm{MWe}$ high-temperature Generation IV reactor is scheduled to be operational in South Africa by 2005. In addition to the Generation IV initiative, R\&D work on high-temperature reactors is taking place within the European Commission's 5th Framework Programme with participants from a number of countries.

\section{Market potential}

Applications

Costs 2002

Expected

maximum

market share

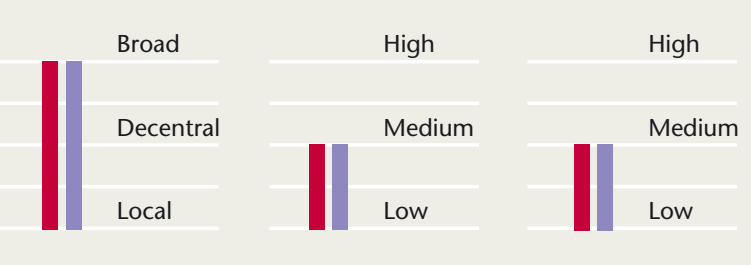

\section{Prospects in Denmark}

For undertaking

the necessary

For industrial production

For export

research

High

High

High

Medium

Medium

arigh

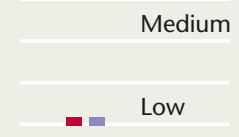

Low

Medium

- Low $=$ Low

Low

\section{Nuclear power research at Risø}

Risø National Laboratory was founded in the late 1950s. One of its original aims was to contribute to the introduction of nuclear power plants in Denmark. During the first 20 years Risø scientists worked on various aspects of nuclear technology, including reactor concepts.

In 1976 the decision on whether to include nuclear power in Danish energy plans was postponed, and Risø's work on nuclear power focused on safety aspects.

In 1985 Denmark decided not to build any nuclear power stations. Nuclear safety research at Risø was reduced to the level needed to run the laboratory's own nuclear facilities and support Danish emergency plans for nuclear accidents in other countries.
In 2000 Risø's remaining nuclear reactors were closed, and reactor physics research was directed towards decommissioning.

Today, Risø's research in nuclear technology takes place mainly in the Radiation Research and Systems Analysis Departments. The Radiation Research Department works on nuclear safety, radiation protection, emergency preparedness, radioactivity in the environment and applications of nuclear methods in industry and medicine. Nuclear research focuses on decommissioning, management of radioactive waste and emergency preparedness. 


\section{Fusion energy}

JENS-PETER LYNOV, OPTICS AND FLUID DYNAMICS DEPARTMENT, RIS $\varnothing$

\section{Rationale behind fusion energy research}

Nuclear fusion - the joining of light atomic nuclei to form heavier nuclei - has the potential to provide large amounts of energy, with important environmental advantages, within 50 years or so. The main advantages of fusion energy are that it is a practically inexhaustible energy source and that it produces no $\mathrm{CO}_{2}$. The following paragraphs describe the key features of fusion energy. ${ }^{129}$

Fusion energy will be based on the fusion of two heavy isotopes of hydrogen: deuterium and tritium. We have huge reserves of these materials, and as Table 9 shows, the amounts needed in a fusion power station are very small.

Every cubic metre of water contains around $35 \mathrm{~g}$ of deuterium. Tritium occurs naturally only in trace quantities because it is radioactive, with a half-life of about 12 years. However, tritium can be produced artificially in a fusion reactor from lithium, which is one of the most abundant light materials in the earth's crust.

Safety studies ${ }^{130}$ have shown that a fusion power station can be operated without risk of radioactive emissions harmful to humans and the environment. The thermal energy content of the burning fusion fuel is so low that melting of the fuel container is impossible. The maximum amount of tritium that could be released in any conceivable accident is so small that the area surrounding the power station would not need to be evacuated.

Neither $\mathrm{CO}_{2}$ nor any other greenhouse gas is released from a fusion power plant.

Fusion creates neutrons which are absorbed by the walls of the fuel chamber, making the wall materials radioactive and changing their properties. Results from current materials development studies show that the radioactivity of fusion waste will decay rapidly; ${ }^{131}$ after about a hundred years the waste will be less radioactive than the ash from coal-fired power stations. However, nuclear waste from fusion is still a problem to be addressed carefully.

The unit size of a future fusion power station is expected to be approximately 2 GWe. The characteristics of a fusion power station dictate that it must run continuously as a base-load power source.

Fusion energy requires a reactor temperature of 100 million ${ }^{\circ} \mathrm{C}$ or higher. This is a big challenge for science and technology, but the past 20-30 years have seen significant progress in fusion $\mathrm{R} \& \mathrm{D}$, including temperatures above 200 million ${ }^{\circ} \mathrm{C}$.

Figure 26 shows that progress in fusion research,
Table 9: Fuel consumption for different energy production methods.

\begin{tabular}{|c|c|}
\hline Plant type & $\begin{array}{l}\text { Annual fuel consumption for a } \\
1000 \text { MWe power plant }\end{array}$ \\
\hline Coal & $2.700 .000 \mathrm{t}$ \\
\hline Oil & $1.900 .000 \mathrm{t}$ \\
\hline Fission & $28 \mathrm{t}$ of $\mathrm{UO}_{2}$ \\
\hline Fusion & $100 \mathrm{~kg}$ deuterium and $150 \mathrm{~kg}$ tritium \\
\hline
\end{tabular}

measured in terms of the "triple product" (defined as the product of plasma temperature, plasma density and plasma energy confinement time), is as rapid as the growth in PC computer power, measured in terms of the number of transistors on a chip.

\section{Present status of fusion research}

Several different schemes can provide the physical conditions needed to obtain fusion and use it as a source of energy. By far the most successful of these is known as magnetic confinement.

At the high temperatures needed for fusion, the fuel takes the form of a plasma - a completely ionised gas. Magnetic confinement uses strong magnetic fields to keep the hot plasma away from the walls of the reaction chamber. The chamber itself is shaped like a doughnut,

Figure 26: Source: J.B. Lister, CRPP, Switzerland.

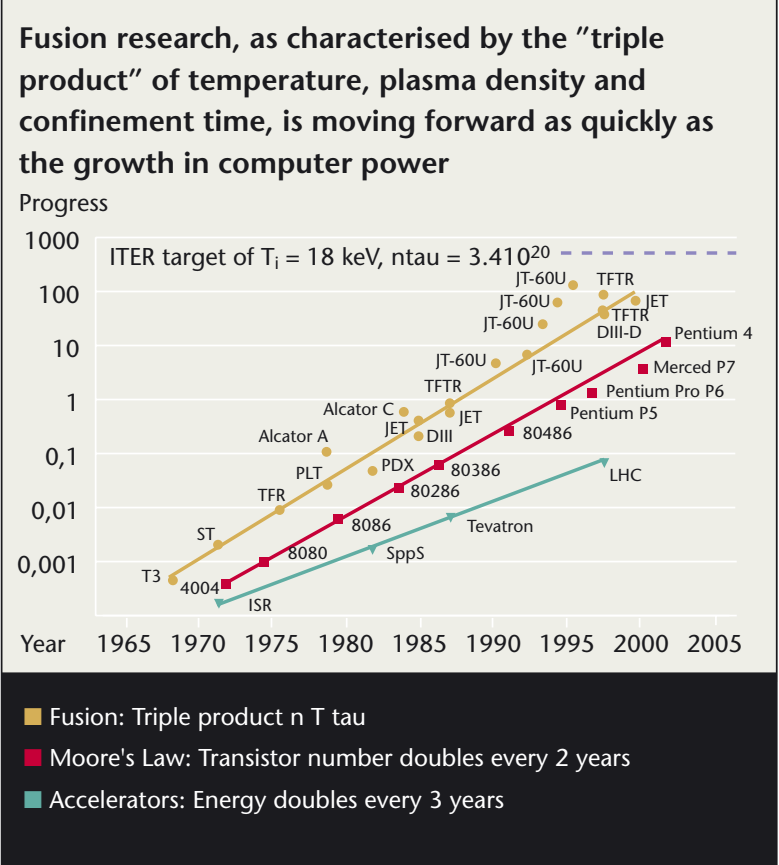


otherwise known as a "torus". This shape allows the magnetic field to form closed loops, squeezing the plasma into a ring.

Because the plasma does not touch the walls of the torus, magnetic confinement also provides effective thermal insulation, with temperature gradients of more than $100,000,000^{\circ} \mathrm{C} / \mathrm{m}$

The necessary magnetic fields are generated by electric currents, flowing either in coils outside the plasma chamber or within the plasma itself. Most fusion research uses an arrangement known as a tokamak, which uses both external currents in magnetic coils and internal currents inside the plasma. One drawback to this approach is that it is difficult to maintain the internal currents without short interruptions, since they are most effectively produced via an electric transformer with an alternating external current.

An alternative arrangement known as a stellarator is easier to operate in an uninterrupted, or steady-state, mode, since it only relies on constant external currents in magnetic coils. So far, however, the progress of stellarators is considerably behind that of tokamaks.

The largest fusion experiment in the world is a tokamak called JET (the Joint European Torus), located near Oxford in the UK and built by scientists and engineers from all over Europe. In 1997 JET managed to produce almost enough power from fusion to keep the plasma at its operating temperature, a condition known as scientific breakeven. This result and others have exceeded the original aims of JET.

From 1997 to 2000 the European fusion programme funded studies of the socio-economic aspects of fusion power under the SERF1 (1997-98) $)^{132}$ and SERF2 $(1999-2000)^{133}$ programmes. These studies show that without any constraints on pollution, neither fusion nor renewables can compete effectively economically with coal on the energy market in Western Europe.

If $\mathrm{CO}_{2}$ constraints are imposed, however, fusion power can play an important part in meeting Europe's energy needs in the course of the 21st century. The studies show that renewables and fusion can play complementary roles, because of their suitability as intermittent and base-load power sources, respectively.

Public interest in fusion is limited because of the long timescale needed to develop practical fusion power. Any problems with the acceptance of fusion seem to be more to do with justifying research funding on such a long timescale than with concern for risks associated with the technology.

\section{Alternative fusion technologies}

A fusion technique known as inertial confinement, ${ }^{134} 135$ provides an alternative to the magnetic confinement of a plasma. In inertial confinement, fuel pellets a few millimeters in diameter are irradiated by high-power lasers or particle beams. For around a billionth of a second, each fuel pellet is compressed and heated strongly enough to allow fusion reactions to take place.

After this billionth of a second the pellet's inertia can no longer contain the energy supplied by the irradiating beam and the subsequent fusion reaction, and the pellet explodes. A power station using inertial confinement would process fuel pellets at the rate of 10-20 per second. In several countries, research in inertial confinement is supported by military budgets and partly classified, because of its relevance to nuclear weapons.

\section{International $R \& D$ and plans}

Large fusion research programmes are under way in Europe, Japan, the USA and Russia.

In Europe, EURATOM co-ordinates the fusion research programme. The members of the EURATOM fusion programme are all the EU countries plus Switzerland, Hungary, the Czech Republic and Romania.

Scientists from the EURATOM fusion programme, Canada, Japan and the Russian Federation are now working together on the next major development in fusion: ITER (which means "the way" in Latin). ITER is an experimental tokamak that will produce as much thermal energy as a conventional power station. ITER will take about ten years to build, and research and optimization of operation is estimated to last about another 15 years. In a subsequent, partly overlapping, step, a new machine will be built to demonstrate fusion in a complete, electricity-producing power station. Testing and optimising this demo power plant will probably take a further 15 years

In parallel to this work, scientists need to develop highlyresistant, low-activation materials for use in the reactor core. Altogether, fusion could be available as a commercial source of energy around the middle of this century. 50 years is a long time for an international partnership. In 1999, the US left the ITER collaboration and shifted the focus of fusion research from fusion as a future energy source to the scientific aspects of plasma physics. This move was supported in 2001 by an assessment ${ }^{136}$ of the US Department of Energy's Office of Fusion Energy Sciences. However, at a large meeting ${ }^{137}$ in Snowmass, Colorado, in July 2002, the US fusion experts re-assessed which way to go and concluded that the US should rejoin the ITER process as a full partner. The output of this meeting will be the basis for a proposal to the US President to be prepared by the Fusion Energy Science Advisory Committee at the end of 2002. ${ }^{138}$ 


\section{Indicators for the fusion energy technology}

\section{Fusion energy}

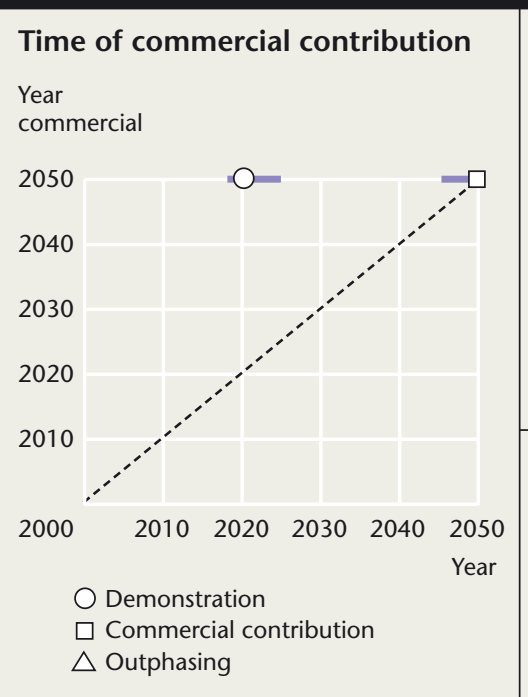

\section{Market potential}

Applications

Costs 2002

Broad

Decentral

\section{$\mathrm{CO}_{2}$ reduction potential}

Emission

reduction

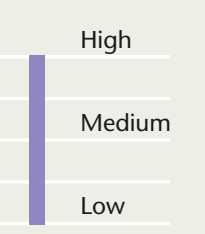

Expected impact

on energy system in 2030

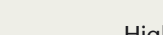

\section{Needed investments}

In basic and applied research

In development and demonstration

Without any constraints on pollution, neither fusion nor renewables can compete economically with coal on the energy market in Western Europe. If $\mathrm{CO}_{2}$ constraints are imposed, however, fusion power could play an important part in meeting Europe's energy needs in the course of the 21 st century. Renewables and fusion can play complementary roles, because of their suitability as intermittent and base-load power sources, respectively.

\begin{tabular}{|c|c|c|c|c|c|c|}
\hline Applications & Costs 2002 & $\begin{array}{l}\text { Expected } \\
\text { maximum } \\
\text { market share }\end{array}$ & $\begin{array}{l}\text { For undertaking } \\
\text { the necessary } \\
\text { research }\end{array}$ & $\begin{array}{l}\text { For industrial } \\
\text { production }\end{array}$ & For export & \\
\hline Broad & High & High & High & High & & High \\
\hline Decentral & Medium & Medium & Medium & Medium & & Medium \\
\hline Local & Low & Low & Low & Low & 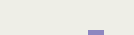 & Low \\
\hline
\end{tabular}

\section{Fusion research at Risø}

The co-ordination of fusion research provided by EURATOM means that Risø can concentrate on what it does best ${ }^{140}$ rather than having to cover the whole field of fusion research.

Risø's fusion work falls in two main areas: plasma physics and materials technology. An important topic in plasma physics is large-scale computer simulation of plasma turbulence based on first principles. Another important subject is diagnostics for remote measurements of physical properties inside the hot plasma. The two main diagnostic systems developed at Risø use lasers to characterise plasma turbulence and microwaves to measure the distribution of fast ions in the plasma.
In materials technology, the main research topic is the effect of neutron irradiation on the physical and mechanical properties of materials for fusion machines. The emphasis of these studies is on copperbased alloys, which are relevant to ITER, and iron-based alloys, which would be needed for a power-producing fusion reactor. Risø scientists carry out their experiments in collaboration with nuclear research facilities in Europe and USA. Their work includes theoretical studies of defect accumulation, radiation hardening and plastic instabilities, with extensive use of computer models developed at Risø. 


\section{Superconductivity}

NIELS HESSEL ANDERSEN AND JEAN-CLAUDE GRIVEL, MATERIALS RESEARCH DEPARTMENT, RIS $\varnothing$

\section{Perspectives}

Superconductors are materials that can transport electricity without any loss of energy. They offer huge opportunities in electricity transmission systems, motors, generators, transformers and electromagnets, and correspondingly huge challenges to R\&D.

From the mid-1970s to the mid-1980s, traditional metallic superconductors operating at cryogenic temperatures matured into a niche market. It was the discovery of high-temperature superconductivity (HTS) in 1986, however, that held out the promise of superconducting components in day-to-day applications.

Now immense efforts are being made to improve the current-carrying capacity, known to scientists as the critical current $\left(I_{c}\right)$, of high-temperature superconductors, and to develop new materials that are superconducting at ever-higher temperatures.

The record for the highest critical temperature $\left(T_{c}\right)$, below which a material acts as a superconductor, is 165 $\mathrm{K}\left(-108^{\circ} \mathrm{C}\right)$. Research programmes driven by the vivid hope of developing a room-temperature superconductor have now synthesised and tested many hundreds of candidate materials.

Other research objectives are a fundamental theory of HTS and an understanding of exactly how the critical current depends on the magnetic field and temperature.

\section{Properties}

Apart from electric cables, a prime use for superconductors is to generate magnetic fields in motors, generators and scientific instruments. Superconductivity and magnetism are usually considered to be mutually exclusive, so understanding their interplay is a key topic at every level of superconductivity R\&D.

A fundamental property of electrons in the superconducting state is that they form pairs of opposite spin, but these pairs break up when exposed to a sufficiently high magnetic field. In an attempt to stop this happening, the superconducting electrons form circulating lossless super-currents that exclude the magnetic flux or isolate it into small quantised units called magnetic vortices.

Although high-temperature superconductors can resist very high magnetic fields, theoretically up to 300 tesla, the interaction between transport currents and magnetic vortices can cause serious problems. If not "pinned" in place, the vortices move, causing losses that will destroy superconductivity.

\section{Superconducting tapes}

Significant effort is now being put into developing and improving HTS "tapes" based on the material (Bi,Pb)-Sr-
Ca-Cu-O (BSCCO) in silver (Ag) tubes, using the so-called powder-in-tube (PIT) technique. These tapes are currently sold by companies in the USA, Europe and Japan. The world's leading manufacturer is the American Superconductor Company, but the Danish company Nordic Superconductor Technologies A/S (NST) and its German collaborator Vacuumschmeltze $\mathrm{GmbH}$ are strong competitors.

BSCCO/Ag tapes can be used for power transmission cables at $77 \mathrm{~K}$, using liquid nitrogen as the cooling medium. However, for magnetic field applications they are only suitable at temperatures below $30 \mathrm{~K}$. At higher temperatures the vortex pinning is too low and superconductivity disappears at moderate magnetic fields and transport currents.

For magnetic field applications at $77 \mathrm{~K}$ the emphasis is on "coated conductor" tapes based on the material $\mathrm{YBa}_{2} \mathrm{Cu}_{3} \mathrm{O}_{6+\mathrm{x}}(\mathrm{YBCO})$. In 5-10 years, once it is fully developed, YBCO may also become a strong competitor for electricity transmission.

A superconductor that works at room temperature is the ultimate goal. While such a material remains to be discovered, other superconductors with particular properties are proving attractive even if their critical temperatures are relatively low.

Recently the material $\mathrm{MgB}_{2}$ was discovered to be a traditional superconductor - in other words not an HTS with the unusually high critical temperature of $39 \mathrm{~K}$. Encapsulated in a metal sheet, $\mathrm{MgB}_{2}$ can be processed into a low-cost superconducting tape that has attractive properties for many applications at $20 \mathrm{~K}$. This temperature, although low by HTS standards, can be reached relatively simply by modern closed-cycle cryogenic systems.

\section{Applications}

Applications for superconductivity range from highpower electric transmission lines to ultra-fast electronics. Most activity is in the energy sector, where superconducting tapes and wires are being developed for the electric power system transmission and a range of magnetic field applications.

In the total electric power energy system the major losses are in the steam and gas turbine cycles with conversion efficiency in the range of $30-50 \%$. Conventional generators, motors and stationary transformers have efficiencies higher than typically $96 \%$, and the total losses in the transmission and distribution system are of the order of $10 \%$. Including refrigeration costs these losses may be halved by introduction of HTS technology, but only in large-scale facilities. Similar figures and restrictions hold 
for superconducting motors, and in the US, for example, motors larger than $1000 \mathrm{hp}$ consume nearly $50 \%$ of the electric power. If HTS motors with an improved efficiency of $2 \%$ are introduced, e.g. over the next 10 to 20 years, the final saving would amount to about US $\$ 2$ billion/year. Similarly, if the losses in the power generation and transmission system is halved the resulting saving in the US would be US\$10 billion/year. Therefore, relatively small improvements may lead to rather large savings. Development of transformers for electrified trains is an especially attractive HTS technology niche because an efficiency gain from about $90 \%$ to $98 \%$ can be achieved in transformers that are significantly smaller and lighter. Even with the present technology the forecasts indicate large-scale HTS systems that are cost efficient both on fabrication and during operation. Moreover, the performance of HTS components is superior to conventional units, e.g. by allowing non-fatal overloads and more dynamical operation, being significantly smaller and lighter, and having environmental advantages. The present and new superconductors with improved properties may change the situation more dramatically. BSCCO/Ag tapes manufactured by NST have been used for the first superconducting power transmission cable ever installed in a utility network. This three-phase cable $(2 \mathrm{kA}, 36 \mathrm{kV})$ has been in operation at the Amager coupling station in Denmark since May 2001. The cable is cooled by liquid nitrogen circulated through an internal tube.

Several companies in the USA, Europe and Japan have developed HTS cables based on BSCCO/Ag tapes. For most uses the cables are still not economically competitive with conventional cable technology, and further development and price reduction are clearly necessary. In special applications, however, we may see BSCCO/Ag cables being used quite soon. An example might be in uprating the electricity supply to an urban area, where the existing cable passes through a tunnel that restricts its diameter or the amount of heat that can be dissipated. Because superconducting cables can carry about 5 times more current for the same diameter, and produce no heat, they may be more cost-effective than replacing the complete cable tunnel. Environmental considerations related to pollution, $\mathrm{CO}_{2}$ release, noise and reduced fire hazard add to the significant advantages of HTS technology.
In the longer term, YBCO superconducting cables may become the choice for electric power transmission, unless new materials with better superconducting performance are developed in the meantime. It has been estimated that YBCO-based coated conductors will eventually become 10-25 times cheaper than BSCCO/Ag tapes.

As mentioned above a major Incentive for the energy sector, however, is the prospect of superconductors that will allow the development of smaller, and highly efficient and versatile electric motors, generators, transformers, current fault limiters, superconducting magnetic energy storage (SMES) systems, magnetic bearings for fly-wheels and magnetic coils for fusion reactors. Other possible applications include magnetically levitated trains, electromagnets for mineral separation, marine outboard motors, MRI scanners and particle accelerators.

Bulk superconductors with good vortex pinning can exclude magnetic flux, forming a shield against magnetic fields, or trap the flux to form a permanent magnet. Such superconductors can withstand high current densities (up to $10^{7} \mathrm{~A} / \mathrm{cm}^{2}$ at $77 \mathrm{~K}$ ) and high magnetic fields. Standard soft iron cores in electromagnets become saturated at magnetic fields of about 1.5 tesla. Suitable HTS materials can operate as permanent magnets by magnetic flux trapping up to several tesla, and HTS magnetic coils may produce fields of several tens of tesla.

With the present HTS technology it has been estimated that superconducting transformers, motors and generators will be about 3-25 times smaller and lighter than their conventional counterparts, with significantly improved flexibility, performance on overload and lower power losses. Prospects for even better performance are foreseen if materials properties are significantly improved. Such machines would be especially attractive for electric cars, trains and ships, and for the multimegawatt generators of the next generation of wind turbines.

Even the newly discovered superconductor $\mathrm{MgB}_{2}$, with its comparatively low operating temperature, may be attractive for many applications where cooling can be supplied by a local cryogenic plant or liquid hydrogen system. 


\section{Indicators for the superconductor technology}

\section{$\mathrm{BSCCO} / \mathrm{Ag} \square \mathrm{MgB} 2 /$ metal $\square$ Coated conductor}

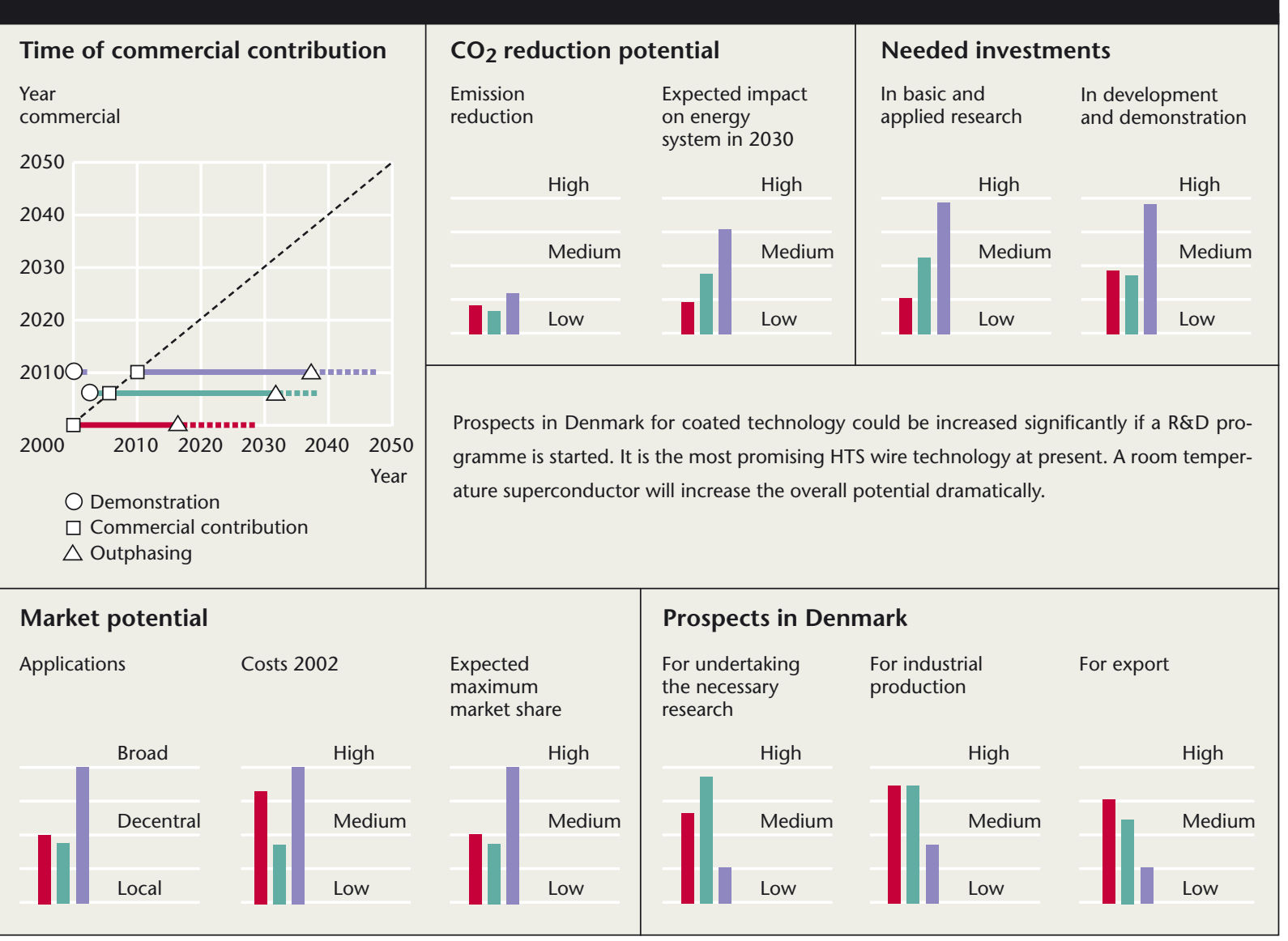

\section{Superconductivity R\&D at Risø}

The Materials Research Department at Risø has a broad programme of superconductivity R\&D. The work includes studying the basic mechanisms underlying high-temperature superconductors and their magnetic properties, developing new superconducting materials, and helping Danish firms with their development programmes.

The Danish Energy Authority, the Danish Technical Research Council and the Danish Natural Science Council have supported these activities for many years. The Technical Research Council has recently set up a five-year framework programme to promote a broad Danish collaboration in superconductor R\&D. The participants include Risø, the University of Copenhagen, the Technical University of Denmark and the companies NST, Haldor Topsøe A/S and DANFYSIK A/S.

The consortium's activities include improving the performance of $\mathrm{MgB}_{2} /$ metal tapes and studies of new superconductor materials with a view to discovering a room-temperature superconductor.

Both the framework programme and the Risø Materials Research Department emphasise the use of neutron and $\mathrm{x}$-ray synchrotron scattering to study fundamental properties of superconductors. This work will help to explain the basic mechanisms of HTS and solve the problems associated with magnetic vortices that are so important for practical applications.

The framework partners are currently discussing whether to start a development programme on coated conductor materials. Risø has a potential interest in starting a development programme on coated conductors to ensure Danish participation in the future superconductor technology. Significant external financing is required to establish a credible effort in this very demanding field. 


\section{Index}

Advanced Gasification Combustion 45

Biodiesel 21, 40

Bioenergy 40-41

Bioethanol 40-42

Biofuel 40-42

Biofuels 5

Biogas 40-41

Biomass 4-5, 8-9, 12-13, 21, 32-33, 40, 42-43, 47

BWR (Boiling water reactors) 47

Carbon sequestration 21

CDM 14

CHP (Combined Heat Power) 11-12, 16-17, 29-30, $32-$

33,43

Decarbonisation 45

Developing countries 3-4, 6-8, 10, 26, 36

District heating 11, 16

Electricity demand $12,24,27$

Electricity supply $12,26,28,32-33,54$

Electricity transmission 53

Energy carrier 22

EURATOM 51-52

EWEA (European Wind Energy Association) 24

Externalities 24

Fast breeder reactors $46-47$

Fission 20, 48

Fusion 4-5, 20, 50-52, 54

Gasification 5, 33, 40, 43-45, 47

GHG (Greenhouse gases) 4, 11, 13-15

Green certificate market 4, 11, 13-14

High-temperature reactors $46-47$

Hybrid system 27, 30

Hybrid systems 26

Hydrogen 18, 22, 44
IAEA (International Atomic Energy Agency) 46

IEA (International Energy Agency) 3, 6, 7, 9, 19-20, 2627

IGCC (Integrated gasification combined cycle) 43-45

Integrated energy systems $16,18,27$

IPCC (Intergovernmental Panel on Climate

Change) 4, 6-7

ITER 51-52

JET (Joint European Tours) 51

Joint Implementation 14

Kyoto Protocol 4, 6, 11, 13, 20, 26

Liberalised power market 13

Light water reactor 46,47

MCFC (Molton carbonate fuel cells) 29

Natural gas 4-5, 8, 10, 14-17, 19-20, 29, 32, 43

NEA (Nuclear Energy Agency) 46

OECD (Organisation for Economic Co-operation and Development) 4, 8, 19-20, 46

PEMFC 33

Phosphoric acid fuel cells 29

PV (Photovoltaics) 36-39

PWR (Pressurised water reactor) 47

Renewable energy 4, 8-9, 11-18, 20, 27, 32-33, 40

Security of supply 4, 13-16

SOFC (solid oxide fuel cells) 29-31, 33

Solar energy $5,8,13,21,32,36$

Superconductivity 53,55

WEC (World Energy Council) 3-4, 7-9, 20 
1. IEA (2001), World Energy Outlook, OECD/IEA 2001

2. IEA (2001), World Energy Outlook, OECD/IEA 2001, IEA, 1998

3. Morita and Lee, 1998

4. IPCC, 2000. SRES

5. IEA (2001), World Energy Outlook, OECD/IEA 2001

6. Nakicenovic, N., A. Grübler, and A. McDonald, eds.(1998). Global Energy Perspectives. Cambridge, Cambridge University Press.

7. IIASA (2002). www.iiasa.ac.at/cgi-bin/ecs/book_dyn/bookcnt.py.

8. Energy Information Administration (2002). International Energy Outlook 2002, National Energy Information Center, Washington

9. Nielsen, L.H. (ed.) (1994), Vedvarende energi i stor skala til el og varmeproduktion (in Danish, 'Renewable Energy for Large-Scale Power and Heat Production in the Future Danish Energy System', Main Report), RISø-R-784, Risø National Laboratory, Roskilde

11. Integration of Renewable Energy Sources and Distributed Generation in Energy Supply Systems, European Communities 2001

12. Nielsen, L.H. (ed.) (1994), Vedvarende energi i stor skala til el og varmeproduktion (in Danish, 'Renewable Energy for Large-Scale Power and Heat Production in the Future Danish Energy System', Main Report), RIS $\varnothing-R-784$, Risø National Laboratory, Roskilde

13. Nielsen, L.H.; Morthorst P.E. (ed.) (1998), Fluktuerende vedvarende energi i el- og varmeforsyningen - det mellemlange sigt (in Danish, 'System integration of wind power on liberalised electricity market Conditions, Medium term aspects), RIS $\varnothing-\mathrm{R}-1055$, Risø National Laboratory, Roskilde

14. Nielsen, L.H.; Jørgensen K. (2000), Electric vehicles and renewable energy in the transport sector. Main focus: Battery electric vehicles and hydrogen based fuel cell vehicles, RIS $\varnothing-R-1187$, Risø National Laboratory, Roskilde

15. European Commission (2000), Green Paper - Towards a European strategy for the security of energy supply COM (2000)769, November 2000

16. Day and Shoemaker, 2000; 2

17. Grupp and Linstone, 1999

18. OECD/IEA, 2000, p28

19. OECD/IEA 2001, Toward a sustainable energy future

20. OECD/IEA 2001, Energy Policies of IEA Countries

21. WEC, 2001

22. IEA/OEC, 2000, p164

23. OECD/IEA, 2002

24. Cahill, Eamon; Fabiana Scapolo (1999), The Futures Project. Technology map.EUR 19031EN, December 1999

25. Coates, Joseph F.; John B. Mahaffie; Andy Hines (2001), 2025: Scenarios of US and Global Society Reshaped by Science and Technology. Oakhill Press. (Downloaded from: www.coatesandjarett.com/2025.htm)

26. European Commission (2000), Green Paper - Towards a European strategy for the security of energy supply COM (2000)769, November 2000
27. OECD/IEA (1997), Energy Technologies for the 21st Century, OECD/IEA, Paris

28. OECD/IEA (2000), Energy Technology and Climate Change - A call for Action. OECD/IEA, Paris

29. OECD/ IEA 2000, Experience curves for energy technology policy

30. OECD (2000), Science, Technology and Industry Outlook 2000, OECD, Paris

31. OECD/IEA 2001, Energy Policies of IEA Countries, Paris

32. OECD/IEA 2002, Vision for the 21st Century. Zero Emissions Technologies for Fossil Fuels. Technology Status Report. Draft of February 2002

33. WEC (2001), Energy Technologies for the Twenty-First Century

34. International Wind Energy Development, World Market Update 2001, BTM Consult ApS

35. WINDPOWER NOTE Nr. 27 Marts 2002, Vindmølleindustriens Årsberetning (in Danish)

36. International Energy Agency (IEA R\&D Wind), Annual Report 2001 (Danish contribution)

37. International Wind Energy Development, World Market Update 2001, BTM Consult ApS

38. Proceedings of the European Wind Energy Conference, Copenhagen, Denmark, 2-6 July 2001, Wind Power: Achievements and Perspectives, by A. Zervos, pp. xxxviii-xlii

39. European Commission: Future Needs and challenges for NonNuclear Energy Research in the European Union, Discussion Paper Dec. 2001

40. International Wind Energy Development, World Market Update 2001, BTM Consult ApS

41. WINDPOWER NOTE Nr. 27 Marts 2002, Vindmølleindustriens Årsberetning, in Danish

42. International Wind Energy Development, World Market Update 2001, BTM Consult ApS

43. Proceedings of the European Wind Energy Conference, Copenhagen, Denmark, 2-6 July 2001, Opening Address by Knud Pedersen, Ministry of Enviroment and Energy, Denmark, pp. xii-xxiii

44. International Energy Agency (IEA R\&D Wind), Annual Report 2001, (Danish contribution)

45. ECOTEC report for DG Environment: "Renewable Energy Sector in the EU: its' Employment and Export, 1999

46. Proceedings of the European Wind Energy Conference, Copenhagen, Denmark, 2-6 July 2001, Achievements and Perspectives, by A. Zervos, pp. xxxviii-xlii

47. 35th IEA Topical Expert Meeting: "Long Term R\&D Needs 2000-2020", March 2001

48. Wind Force 10, A Blueprint to Achieve 10\% of the World's Electricity from Wind Power by 2020. EWEA et al, 1999

49. International Wind Energy Development, World Market Update 2001, BTM Consult ApS

50. Wind Force 10, A Blueprint to Achieve $10 \%$ of the World's Electricity from Wind Power by 2020. EWEA et al, 1999 
51. Proceedings of the European Wind Energy Conference, Copenhagen, Denmark, 2-6 July 2001, Achievements and Perspectives, by A. Zervos, pp. xxxviii-xlii

52. P.E. Morthorst: Vindmøllers økonomi - kan vindmøller konkurrere på markedsvilkår i fremtiden? Høring om vindkraft i det danske Folketing, 14 marts 2002 (in Danish). (Economics of wind power can wind power economically compete on commercial terms in the future? Public hearing in the Danish Parliament, 14th March 2002). (Is published at www.Windpower.org)

53. European Commission Green paper: "Towards a European Strategy for the Security of Energy Supply, Nov. 2000

54. Proceedings of the European Wind Energy Conference, Copenhagen, Denmark, 2-6 July 2001, Achievements and Perspectives, by A. Zervos, pp. xxxviii-xlii

55. 35th IEA Topical Expert Meeting: "Long Term R\&D Needs 2000-2020", March 2001

56. Evaluation of Risø National Laboratory, Ministry of Information Technology and Research May 2001

57. Dansk Forskningskonsortium for Vindenergi, En Strategisk Analyse, Februar 2002, Forksningscenter Risø, Danmarks Tekniske Universitet, Aalborg Universitet, DHI - Institut for Vand og Miljø

58. Energistyrelsen: "Rapport fra arbejdsgruppen om kraftvarme- og VE-elektricitet", oktober 2001

59. European Commission, EUR 19429: “Integration of Renewable Energy Sources and Distributed Generation in Energy Supply Systems"

60. DEWEK 2000 (Deutsche Windenergiekonferenz), G. Czisch (ISET) and G. Giebel (Risø): "A Comparison of Intra- and Extraeuropean Options for an Energy Supply with Wind Power", 69-72

61. G. Giebel: "On the Benefits of Distributed Generation of Wind Energy in Europe", Reihe 6 Nr. 444 VDI Verlag

62. IEA R\&D Wind: "2000 IEA Wind Energy Review"

63. Energistyrelsen: "Danish Energy-Sector Exports", June 2000

64. 35th IEA Topical Expert Meeting: "Long Term R\&D Needs 2000-2020", March 2001

65. A. Valfells, K. Jørgensen, N.-O. Nylund, R. Hagman, H.G. Petterson, B. Gaudernack (ed.), "Introduction to a new, sustainable technology in the Nordic transport sector", NEFP report 2001

66. DG XII-F document: A fuel cell research, development and demonstration strategy for europe up to 2005 ,

http://www.eva.wsr.ac.at/(de)/opet/fcstrategy.htm\#h3

67. A. Valfells, K. Jørgensen, N.-O. Nylund, R. Hagman, H.G. Petterson, B. Gaudernack (ed.), "Introduction to a new, sustainable technology in the Nordic transport sector", NEFP report 2001

68. DG XII-F document: A fuel cell research, development and demonstration strategy for europe up to 2005 , http://www.eva.wsr.ac.at/(de)/opet/fcstrategy.htm\#h3

69. Larsen, P.H.; Bagger, C.; Linderoth, S.; Mogensen, M.; Primdahl, S.; Jørgensen, M.J.; Hendriksen, P.V.; Kindl, B.; Bonanos, N.; Poulsen, F.W.; Maegaard, K.A., Status of the Danish SOFC programme. In: Proceedings. 7. International symposium on solid oxide fuel cells (SOFC 7), Tsukuba (JP), 5-8 Jun 2001. Singhal, S.C.; Yokokawa, H (eds.), (Electrochemical Society, Pennington, NJ, 2001) (Proceedings volume PV 2001-16) p. 28-37

70. M. Conte et al: "Hydrogen economy for a sustainable development state-of-the-art and technological perspectives". Journal of Power Sources, Vol. 100, pp. 171-187, 2001
71. The European Commission: “EUR 19460: A New Framework Programme for European Research - Towards e European Research Area" Luxembourg, 2001

72. The German web-based information service HyWeb. http://www.hydrogen.org/germanh2/index.html

73. Strategic plan for DOE Hydrogen Program, DOE/GO-10098-532, BR-24441, Washington DC, January 1998

74. http://www.eren.doe.gov/hydrogen/research.html

75. "Report from the Working Group on cogeneration of RES electricity" (in Danish), Danish Energy Agency, Copenhagen, October 2001, (ISBN 87-7844-239-7)

76. Amos, W.A.: "Costs of Storing and Transporting Hydrogen", National Renewable Energy Laboratory, U. S. Department of Energy, Golden, Colorado, November 1998

77. US Department of Energy, "A National Vision of America's Transition to a Hydrogen Economy - to 2030 and Beyond". Washington, DC, 2001

78. Petterson, J. \& Hjortsberg, O.: "Hydrogen Storage Alternatives - a Technical and Economical Assessment". KFB-Meddelande, Stockholm, 1999:27

79. Padró, C.E.G. \& Putsche, V.: "Survey of the Economics of Hydrogen Technologies", NREL/TP-570-27079. US Department of Energy, National Renewable Energy Laboratory, Golden, Colorado, 1999

80. Kreutz, T.G. \& Ogden, J.M.: “Assessment of Hydrogen-Fuelled Proton Exchange Membrane Fuel Cells for Distributed Generation and Cogeneration". Proceedings of the 2000 US DOE Hydrogen Program Review, Golden Colorado

81. Sørensen, Bent et al: Scenarios for overall exploitation of hydrogen as energy carrier in the future energy system of Denmark. Final report (in Danish with English summary). Roskilde University Centre, IMFUFA Institute, April 2001

82. IEA Photovoltaic Power Systems Programme

83. US Energy Information Administration, "Renewable Energy annual 2000" DOE/EIA-0603 (2000)

84. United States Photovoltaics Industry, The National Center for Photovoltaics, "Solar Electric Power" (2001)

85. Bruton, T.M., General trends about photovoltaics based on crystalline silicon. Sol. Energy Mater. Sol Cells (2002) 72, 3-10

86. Yang, J.; Banerjee, A.; Guha, S., Trible-junction amorphous silicon alloy solar cell with $14.6 \%$ inital and $13.0 \%$ stable conversion efficiencies. Appl.Phys.Lett. (1997) 70, 2975-2977

87. Wennerberg, J.; Kessler, J.; Hedstrom, J.; Stolt, L.; Karlsson, B.; Ronnelid, M., Thin Film PV modules for low concentrating systems. Solar Energy (2001) 69, 243-255

88. Grätzel, M., Photoelectrochemical cells. Nature (2001) 414, 338-344 89. Shaheen, S.E.; Brabec, C.J.; Sariciftci, N.S.; Padinger, F.; Fromherz, T.; Hummelen, J.C., $2.5 \%$ efficient organic plastic solar cells. Appl. Phys. Lett. (2001) 78, 841-843

90. Green, M.A., Photovoltaic principles. Physica E (2002) 14, 11-17

91. Wronski, C.R., Amorphous Silicon Photovoltaics: Order from Disorder. In: Photovoltaic Specialists Conference, 2000. Conference Record of the Twenty-Eighth IEEE (2000) p. 1-6

92. Scharmer, K. (1993) Umweltaspekte bei Herstellung und Verwendung von RME. In: RME Hearing. Ministry for Agriculture Vienna, Austria

93. A. V. Bridgwater and G. V. C. Peacocke (2000) Fast pyrolysis processes for biomass. Renewable and Sustainable Energy Reviews 4: 1-73 
94. Lynd L. R. (1996) Overview and evaluation of fuel ethanol from cellulosic biomass: Technology, economics, the environment, and policy. Annual Review of Energy and the Environment. 21, 403-465

95. Zaldivar, J., Nielsen, J. and L. Olsson (2001) Fuel ethanol production from lignocellulose: a challenge for metabolic engineering and process integration. Applied Microbiology and Biotechnology, 56, 1734

96. Needs for Renewables. Developing a new generation of sustainable energy technologies. Long-term R\&D Needs. International Energy Agency,October 11, 2000 Paris, France.

97. Körbitz, W., Biodiesel production in Europe and North America, an encouraging prospect. Renewable Energy 16 (1999) 1078-1083.

98. Grassi, D., Modern Bioenergy in the European Union. Renewable Energy 16 (1999) 985-990.

99. Eurec Agency ( $2^{\text {nd }}$ ed. 2002), The Future for Renewable Energy Prospects and Directions. James \&James (Science Publishers) Ltd, London, UK 2002

100. Renewable Energy. Sources for Fuels and Electricity. Ed. T.B Johansson, H. Kelly, AKN Reddy, RH Williams. Island Press 1992

101. http://www.managenergy.net

102. http://www.biomatnet.org/

103. http://www.iea.org

104. Ulrich, G. (1999). The Fate and Transport of Ethanol-Blended Gasoline in the Environment: A Literature Review and Transport Modeling. Governors' Ethanol Coalition: Lincoln, NE

105. McCoy, M. (1998) Biomass ethanol inches forward. Chem. Eng News 7, 29-32

106. Directive for the promotion of renewable energy. European Commision. May 2000

107. Renewable Fuels Association. www.ethanolrfa.org

108a. Ahring B. A., Licht D., Nielsen P., Schmidt A. S. and Thomsen A. B. (1999) Production of ethanol from hydrolysates of wet oxidised wheat straw by thermoanabacter mathranii. Biores. Technol. $68,3-9$

108b. Bjerre A. B., Olesen N. B., Femqvist T., Plöger A. and Schmidt A. S. (1996) Pretreatment Wheat Straw using combined Wet Oxidation and Alkaline Hydrolysis Resulting in Convertible Cellulose and Hemicellulose. Biotechnol. Bioeng. 49, 568-577

108c. Schmidt A. S. and Thomsen A. B. (1997) Optimisation of wet oxidation pretreatment of wet straw. Bioresource Technology, 64, 139-151

109. Ahring BK and Thomsen A. B., patent nr. WO0160752

110. Klinke HB, Ahring BK, Schmidt AS, Thomsen AB (2002) Characterization of degradation products from alkaline wet oxidation of wheat straw. Bioresource Technology 82: 15-26

111. Thomsen A. B. et al., unpublished

112. The Coal Utilization Research Council (CURC) Washington DC, USA (www.coal.org/rdmap.htm)

113. Hustad, Carl-W, Review over recent Norwegian studies regarding cost of low $\mathrm{CO}_{2}$-emission power plant technology. Proceedings from Fifth International Conference on Greenhouse Gas Control Technology, Cairns, Australia, 13-16 August, 2000
114. Marcus, G.H. and Levin, A.E., New Designs for the Nuclear Renaissance, Physics Today, April 2002, pp. 54-60

115. http://gen-iv.ne.doe.gov

116. Trends in the Nuclear Fuel Cycle: Economic, Environmental and Social Aspects, OECD, Paris, 2002

117. Nuclear Energy in a Sustainable Development Perspective, OECD/NEA, Paris, 2000

118. Accelerator-driven Systems (ADS) and Fast Reactors (FR) in Advanced Nuclear Fuel Cycles, OECD/NEA, Paris, 2002

119. http://www.iaea.org

120. Lake, J.A., Bennett, R.G and Kotek, J.F. Next-Generation Nuclear Power, Scientific American, January 2002, 70-79

121. http://www.nea.fr

122. http://gen-iv.ne.doe.gov

123. Trends in the Nuclear Fuel Cycle: Economic, Environmental and Social Aspects, OECD, Paris, 2002

124. Nuclear Energy in a Sustainable Development Perspective, OECD/NEA, Paris, 2000

125. Accelerator-driven Systems (ADS) and Fast Reactors (FR) in Advanced Nuclear Fuel Cycles, OECD/NEA, Paris, 2002

126. http://www.iaea.org

127. Lake, J.A., Bennett, R.G and Kotek, J.F. Next-Generation Nuclear Power, Scientific American, January 2002, 70-79

128. http://www.nea.fr

129. H. Bruhns, Fusion Energy: An Option for the Future, EFDA Information Fusion issue 2000/1, http://efda.ipp.mpg.de/, (2000)

130. SEAFP report (Safety and environmental assessment of fusion), European Commission (1995)

131. SEAFP report (Safety and environmental assessment of fusion), European Commission (1995)

132. R. Saez et al., Socio-economic Research in Fusion SERF 1997-98: Externalities of the Fusion Fuel Cycle. Final Report. Coloccion Docomentos CIEMAT (1999)

133. R. Saez et al., Externalities of Fusion: SERF (1999-2000). Coloccion Documentos CIEMAT (2001)

134. The European Fusion Information Network: "Fusion by Inertial Confinement", http://www.fusion-eur.org/fusion_cd/inertial.htm

135. Per F. Peterson "Inertial Fusion Energy: A Tutorial on the Technology and Economics", http://www.nuc.berkeley.edu/thyd/icf/IFE.html

136. An Assessment of the Department of Energy's Office of Fusion Energy Sciences Program, National Academy Press, Washington, D.C., USA, http://www.nap.edu/catalog/9986.html, (2001)

137. http://web.gat.com/snowmass/

138. EFDA-Newsletter Volume 3 / September 2002, page 7, www.efda.org.

140. Association Euratom - Risø National Laboratory Annual Progress Report 2001. H. Bindslev and B.N. Singh (eds.), Risø-R-1345(EN) (2002) 
The publication and further information

can be obtained from risoe.dk.

The printed publication is for sale at the Information Service Department.

Tel. +4546774004

E-mail: risoe@risoe.dk

Fax. +45 46774013

Price DKK 135 ,- inclusive of VAT.

Risø National Laboratory

Roskilde, Denmark

October 2002 
Risø Energy Report 1

Edited by Hans Larsen and Leif Sønderberg Petersen

Design and production: Rumfang ApS

Printing: CenterTryk, Holbæk

Risø-R-1351 (EN)

ISBN 87-550-3081-5

ISBN 87-550-3082-3 (Internet)

ISSN $0106-2840$ 
